\title{
comunicación, territorio y estigma
}

-análisis de los procesos de estigmatización territorial en los barrios de La Boca e Isla Maciel / aportes a la planificación y gestión de políticas de urbanización de villas y asentamientos_

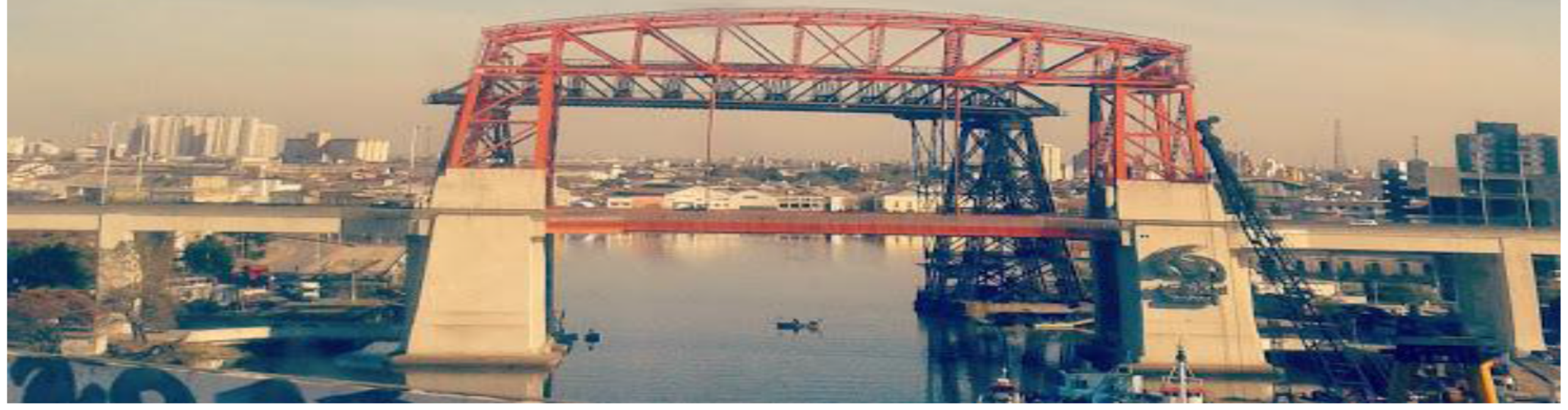


Tesista: Verónica Vidarte Asorey

Director: Carlos Giordano

Institución: Facultad de Periodismo y Comunicación Social, UNLP

Título a obtener: Doctora en Comunicación

Año: 2014 
... A la Universidad pública en la que me formé desde la adolescencia.

A mis compañeros del Colegio Nacional de Buenos Aires con quienes empecé a conocer, a hurgar, a debatir, a sentir la política por entre los claustros, las marchas y los bares. A la Facultad de Peridismo y Comunicación Social, FPyCS, por haberme alojado desde los primeros años de la Licenciatura hasta la instancia del Doctorado; porque ahí aprendí a ser estudiante universitaria, comunicadora, docente e investigadora. A cada uno de los Profesores y compañeros del Doctorado en Comunicación, por compartir el proceso de enseñanza / aprendizaje.

Al Director de la tesis, Carlos Giordano, por la guía, la generosidad y la infinita paciencia. A Javier Auyero y Florencia Saintout que acompañaron, como directores de beca, los primeros pasos de este proyecto. A la Universidad Nacional de La Plata y al Consejo Nacional de Investigaciones Científicas y Tecnológicas por haber vuelto económicamente sustentable parte del proceso de tesis a partir de las becas en Formación Superior en la Investigación Científica UNLP (2009-2011) e Interna de Posgrado Tipo I CONICET (2011-2013) .

Al equipo de Cátedra del Seminario de Tesis de la FPyCS: Silvina Allegretti, Lucas Días Ledesma, Laura Otrocki, Marcos Mutuverría, Fernando Palazzolo y Silvina Souza, porque junto a ellos todos los desafíos propios y ajenos se vuelven aventuras posibles. A los tesistas que tuve $\mathrm{y}$ tengo el privilegio de dirigir, codirigir, asesorar o simplemente intercambiar ideas en las aulas del grado y el posgrado, en los pasillos de la facultad, en el buffet o en las esquinas de la ciudad, cuando nos sorprende el encuentro. A todas y todos ellos por reavivar 
en cada intercambio la pasión por la docencia y la investigación, las ganas de saber / hacer, las convicciones para "inventar" un mundo mejor. A los investigadores, becarios y trabajadores del Instituto de Investigaciones en Comunicación, IICom, por compartirme ese colectivo de trabajo cuyo crecimiento nos enriquece cotidianamente como grupo pero también como personas.

A mis compañeras y compañeros militantes del CEP de La Cámpora por compartir y contagiar la voluntad y el compromiso con la lucha por una patria cada vez más justa, libre y soberana.

A mis amigos, por estar siempre presentes, aún en mis ausencias. A mi familia, a mi abuela Juana, por ser mi mejor agente de prensa desde que tengo memoria. A mi compañero, Ramiro, por el aliento constante y el apoyo incondicional. A mi hija Juanita, porque desde que llegó todo es y será dedicado a ella...

¡Gracias! 


\section{-Índice-}

\section{Introducción}

Qué, porqué y para qué...

\section{Capítulo I}

Territorio y estigma...

Los procesos comunicacionales y la producción de sentido. El orden social y la Cultura. Procesos comunicacionales de exclusión social. Estigmatización y territorio urbano. La construcción de la desviación. Estigmas, outsiders y expectativas de rol. Exclusión e inclusión, el rol del Estado y la Política Social.

\section{Capítulo II}

Lo popular y lo urbano...

Estado de la cuestión, antecedentes teóricos y herramientas conceptuales. Cultura Popular y culturas populares. Los estudios culturales (de los ingleses a los latinoamericanos). Poscolonialismo, subalternidad y subalternizados. Lo urbano en las ciencias sociales. La ciudad global: el gueto y la banlieu. Nueva Pobreza urbana y Tolerancia Cero. Estado gendarme y Estado popular. Ciudades y Metropolización, la ciudad como escenario comunicacional.

Capítulo III

Pasado y presente del hábitat popular... 
Clases populares urbanas. Modelos habitacionales: el conventillo, la villa, el barrio obrero y el asentamiento. La política habitacional del peronismo. Crecimiento de las ciudades latinoamericanas en los períodos industrializador $y$ desarrollista. La dictadura militar y los planes de erradicación. Retorno democrático, "políticas públicas modernas" y radicación. La década neoliberal. Después del $2001,1 a$ década kirchnerista: primera etapa (cambio de paradigma y recentralización), segunda etapa (profundización del modelo). Caracterización de las situaciones habitacional actual en AMBA, políticas sociales y avances legislativos.

\section{Capítulo IV}

Datos e interpretaciones...

Métodos y técnicas. Los casos de análisis (La Boca e Isla Maciel). El trabajo de campo y las entrevistas: informantes clave, entrevistas en profundidad y entrevistas semiestructuradas. Categorías y ejes de análisis. Miedo, violencia $e$ inseguridad. El delito $y$ su percepción. Inseguridad y violencia en los barrios marginalizados; datos duros y estadísticas. Territorios heterotópicos, tópicos y utópicos.

\section{Capítulo V}

Conclusiones y desafíos

Política Social, líneas de acción y ejes de intervención: independencia económica, soberanía política y justicia social. 


\section{Introducción}

El informe de tesis "Comunicación, Territorio y Estigma" es, como opción consciente, un texto poco usual dentro género tesis doctoral, esto obedece a motivos (preguntas, procesos, debates, intercambios y desafíos) a los que me refiero brevemente en esta introducción. Así, menciono algunos aspectos que no se desarrollan en los capítulos que siguen, con el fin de aportar al lector algunas claves sobre los contextos y las temporalidades que atravesaron el proceso de investigación y que configuraron las condiciones de producción de este informe.

Aunque (como en todas las tesis) se buscó dar cuenta de la integración de una serie de conocimientos, recorridos y capacidades aprehendidas y practicadas en el marco del Doctorado; en este caso también se intentó producir un texto corto cuya escritura dialogue con el universo vocabular de los expertos, especialmente los del jurado evaluador, pero que también lo haga con el universo técnico de los planificadores y gestores de la política social y con el político, de los actores que intervienen en los territorios.

Con respecto al primer grupo de destinatarios (expertos evaluadores del informe) cabe aclarar que los considero parte de un grupo más amplio, que contiene también a los jurados de dos tesis anteriores: Tanto en la instancia de defensa de mi tesis de grado en Comunicación Social "La realidad, mirada desde la ficción, en la dictadura de Onganía", como en la de la 
tesis de maestría en Planificación y Gestión Comunicacional "Ni penas, ni olvido. Redes de relaciones organizacionales a orillas del Riachuelo", las devoluciones de los jurados coincidieron en que las debilidades más importantes de esos informes finales se relacionaban con la extensión del texto y la sobreabundancia de reflexión teórica sobre el campo de estudio de la comunicación y la cultura. Por eso, en esta oportunidad me propuse tomar nota de esas recurrencias y trabajar la comunicabilidad del texto según los parámetros antes comentados.

Por otra parte, más allá del texto, el proceso de producción de la tesis tuvo una compleja diacronía: el planteo inicial apuntaba a desentrañar los procesos de estigmatización y su anclaje territorial en barrios ubicados en el margen sur del Riachuelo, aunque tiempo después el objetivo general se terminó definiendo como "aanalizar los procesos de exclusión y estigmatización territorial en el caso de los barrios de La Boca e Isla Maciel, con el fin de producir aportes a las políticas de urbanización de barrios marginalizados en el AMBA". Así, en la primera etapa, los procesos de estigmatización se vinculaban con la construcción del self y del otro (individual y comunitario) en relación con el territorio habitado; pero con el avance de la indagación, los recorridos bibliográficos y el trabajo de campo, esa mirada centrada en los sujetos fue cambiando y dando paso a una focalización orientada al territorio como espacio físico en el que se inscribe el espacio social: un escenario de comunicación constituido de tensiones, desigualdades, luchas concretas y potencialidades de intervención y transformación para las políticas estatales. 
Con respecto al territorio y su abordaje metodológico, uno de los aspectos que no se desarrolla en el cuerpo del informe son las innumerables conversaciones que tuve a lo largo de casi 10 años con vecinos de Isla Maciel-con algunos de ellos hemos ido forjando una amistad-, lo que me convirtió no sólo en testigo directo de sus experiencias habitacionales actuales, sino también de cómo fueron variando esas trayectorias a lo largo del tiempo así como de las narrativas que los vecinos fueron construyendo sobre ellas. En el mismo sentido, tuve la oportunidad de observar las características de la aplicación de sucesivas políticas y el impacto (positivo o negativo) que tuvieron en las condiciones de vida de la comunidad. Todo ello, sin dudas, fue central para establecer criterios que orientaron la interpretación de las entrevistas.

Por otra parte, en la dimensión técnico-política, resultó esclarecedor el proceso de debate, definición y especificación recorrido junto a mis compañeros del Centro de Estudios Políticos de La Cámpora, CEP -especialmente con quienes integran la comisión de Estado y Asuntos Municipales y el Grupo de Iniciativa Legislativa-. En esos intercambios, se definieron conceptos que resultaron gravitantes para esta tesis, como los de urbanización y relocalización en el marco de la política social integrada impulsada por el estado popular; y a la vez descartar otras nociones que no dialogan con los objetivos ni con el escenario teórico (políticas públicas, erradicación, radicación, entre otras).

En otra dimensión, también política pero no técnica sino teórico-epistemológica, debo resaltar el importante aporte que resultó de la labor cotidiana con los miembros del 
Instituto de Investigaciones en Comunicación, IICom, de la facultad de Periodismo y Comunicación Social de la UNLP -sobre todo, con los coordinadores de las líneas de investigación en identidad/es y sujetx/s, cuerpo/s y estigma/s y territorio/s y soberanía/s-. Esos diálogos fueron basales para definir las herramientas conceptuales de la tesis, así como también para ponderar la relevancia del eje inseguridad/violencia/miedo en la investigación de procesos de marginalización territorial.

Por último, gracias a una estadía de investigación que realicé en México en 2012 (en la Universidad de Guadalajara), tuve la oportunidad de entrevistar a consagrados investigadores (como Guillermo Orozco Gómez, Raúl Fuentes Navarro y Enrique Sanchez Ruiz, entre otros)sobre la historia, la actualidad y el futuro del campo latinoamericano de la Comunicación Social. Esas charlas sumadas al incesante diálogo que con el director de la tesis, Carlos Giordano, mantenemos acerca de la tendencia transdisciplinaria de la investigación en comunicación y las condiciones de existencia y de posibilidad de la transdisciplina, fueron los insumos para definir un abordaje transdisciplinario de estos procesos de estigmatización desde el campo de estudios de la comunicación y cultura. De esta experiencia, rescato especialmente la entrevista realizada con la Dra. Rossana Reguillo en el Instituto Tecnológico y de Estudios Superiores de Occidente, ITESSO, con quien pude conversar largamente acerca de las potencialidades de las categorías de territorio tópico, utópico y heterotópico en el análisis de problemáticas vinculadas a la violencia urbana. 
Con todos estos procesos y contextos operando como palimpsestos, se construyó el informe que sigue que (como recomienda Stuart Hall en su texto "Estudios Culturales, dos paradigmas") intenta en ubicarse "en un constante vaivén entre el análisis de la cultura/ideología y sus condiciones de posibilidad" (Hall, 1994). Así, se estudian los problemas del déficit habitacional AMBA vinculados al modo en que durante las décadas del 70, 80 y 90 las políticas erradas y el avance del mercado, en la imposición de intereses particulares por sobre el bien común, generaron consecuencias negativas sobre la vida cotidiana de los sujetos y las comunidades. Como se verá, en este proceso de destitución, los más vulnerables fueron los sectores populares que, paradójicamente, a pesar de ser los más desposeídos de su derecho a la ciudad, son a la vez sindicados como los culpables de sus peores males -que en términos de la agenda de los medios hegemónicos se resume en una sola palabra: inseguridad-. Paralelamente, el mayor problema de la inseguridad urbana (en términos de riesgo de sufrir delitos violentos contra la vida) no es el homicidio en ocasión de robo como insiste en afirmar el discurso mediático, sino las situaciones de violencia cotidiana a las que están expuestos en grado mucho mayor los habitantes de los territorios marginalizados. Por eso, se asumió este fenómeno no sólo como un problema de investigación sino también como un problema de planificación en tanto que su indagación resultó un insumo pensado para aportar a las políticas de urbanización de villas y asentamientos. 


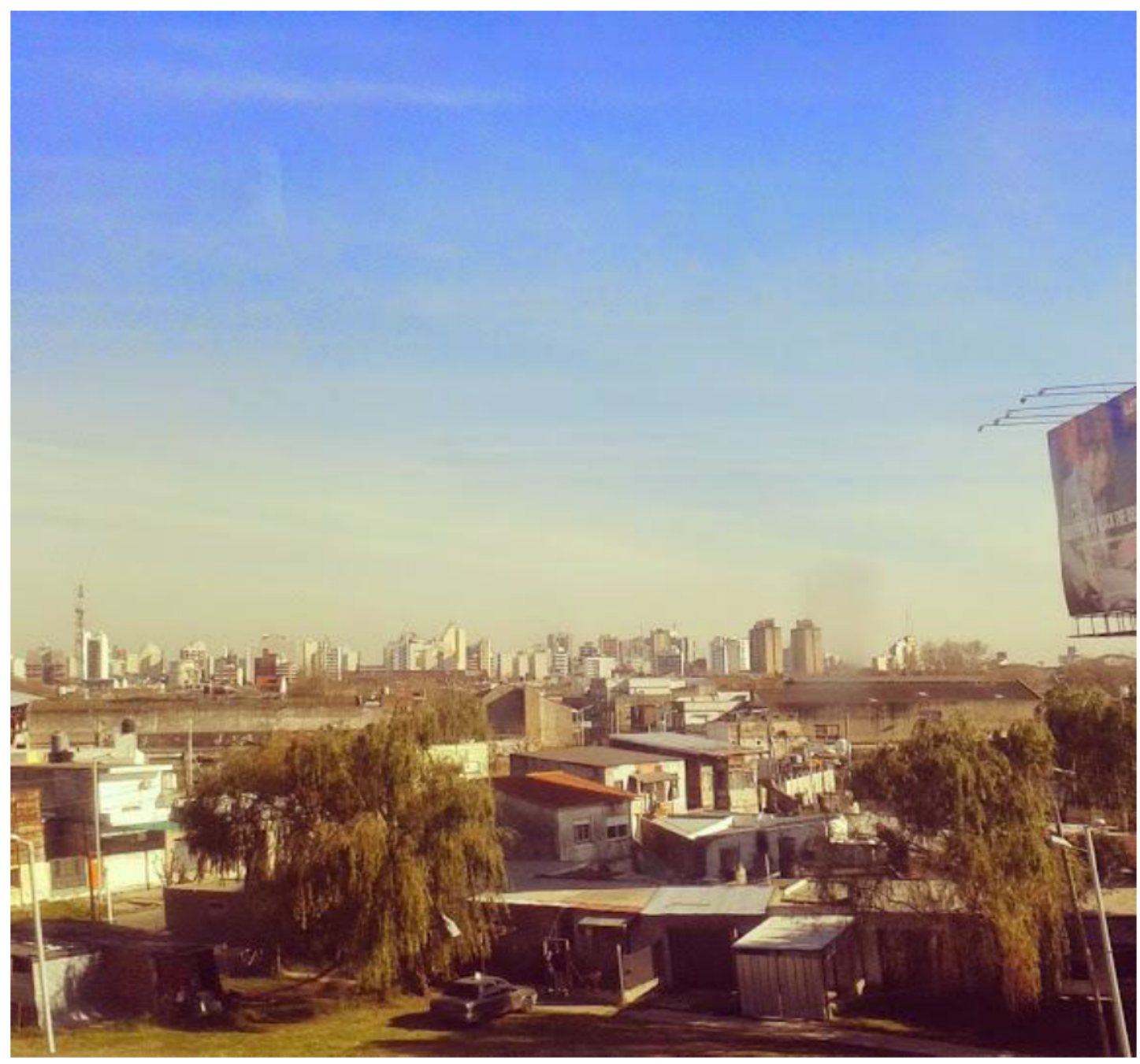


Los procesos comunicacionales son procesos de producción, circulación y uso del sentido social. Estos procesos son simbólicos pero a la vez indisociables de la realidad material, ya que el modo en el que conocemos el mundo y vivimos en él, en interacción con otros, está determinado por el orden social y es a la vez determinante de éste. La estigmatización y la exclusión social son una muestra de cómo los procesos de construcción de sentido se imprimen materialmente en las prácticas y las vidas de las personas.

En este capítulo, intentaremos desentrañar conceptualmente estos procesos propios de lo humano a partir de un recorrido bibliográfico que nos ayuda a reflexionar sobre las condiciones de posibilidad de la marginalización social y los antecedentes teóricos que abordan la problemática, para analizar la experiencia de habitar el territorio y sus vinculaciones con los procesos de exclusión social en el caso de los vecinos de Isla Maciel y La Boca.

Comencemos por pensar lo humano: como el organismo humano es inestable, el mismo sujeto social debe proporcionarle un contorno estable a su comportamiento. De ahí la necesidad antropológica de la externalización, el proceso que determina que una pauta humana se vuelva hábito y se distancie de la experiencia individual: objetivándose, se convierte en pauta social externa a cada sujeto. 
En palabras de Peirce (1987), el proceso que lleva a que una creencia se convierta en verdad permite que los seres humanos asignemos un orden al ambiente, y ciertas pautas de interacción con él, para no enfrentarnos a cada segundo con la necesidad de adquirir pautas de conocimiento sólo a partir de la experiencia personal.

En el curso continuo de esa externalización (o apertura al mundo), la producción humana construye lo que llamamos el orden social a través de ciertos procesos necesarios y particulares: la habituación, la objetivación y la historicidad. Toda actividad humana social o no- está sujeta a habituación, ya que una creencia válida para la regulación de la vida genera una pauta que es aprehendida como tal. El proceso que Berger y Luckman denominaron habituación es análogo a las nociones de habitus de Pierre Bourdieu (1985) y a la de Collegium Logicum de Juan Samaja (2005) .

Aunque la habituación tiene un sentido diacrónico, podemos pensar que Berger y Luckman definen al proceso en movimiento, y Samaja y Bourdieu nos muestran una especie de foto conceptual.

Los procesos de habituación son la antesala de la institucionalización, que es, a su vez, la parte más significativa de aquéllos: "La institucionalización aparece cada vez que se da una tipificación recíproca de acciones habitualizadas por tipos de actores" (Berger y Luckman, 1968). Entonces cuando las prácticas o sentidos son tomados y aprehendidos por un grupo de sujetos como pautas objetivadas en un proceso histórico, se institucionalizan. 
La característica central es la historicidad: la dialéctica histórica permite que las formaciones de sentido trasciendan lo individual y se presenten a los individuos como un hecho externo y coercitivo. El ejemplo más claro es el lenguaje, una tipificación de origen social que se presenta como naturalizada y externa a los sujetos cuando niños, y que determina sus pautas de comunicación con el afuera: los constituye como sujetos sociales. El proceso histórico de objetivación implica la legitimación social de las pautas; luego, los significados legitimados son aprehendidos por las generaciones subsiguientes -en el transcurso de la socialización- dentro del orden institucional.

Por los procesos de habituación e institucionalización, las objetivaciones del sentido subjetivo de la experiencia o del acto pasan a formar parte de los acervos sociales de conocimiento. "La aparición de depósitos de sentido y de instituciones históricas liberan al individuo de la pesada carga de solucionar los problemas de la experiencia y el acto que afloran, como por primera vez, en situaciones particulares" (Berger y Luckman, 1997). El sentido social es un sistema de organización / regulación de la sociedad, y a su vez muestra modos de organización para el acto y la acción: es histórico y prospectivo.

El sentido social es consecuencia de la posibilidad de relacionar distintas experiencias. La vivencia aparece asociada a un tipo o esquema de experiencia. Esto genera "un doble sentido": el de la acción y el del acto. El sentido del acto es retrospectivo: cuando planté maíz en primavera pude cosecharlo en verano; cuando encendí el fuego sobre la tierra en un día ventoso se incendió parte del bosque; si camino por una calle oscura me pueden robar. El 
sentido de la acción, por el contrario, es prospectivo, ya que se configura por anticipado en relación con un propósito: para obtener una buena cosecha en verano debo plantar en primavera; para evitar que me roben no debo salir a caminar de noche por calles oscuras.

Esta compleja estructura de sentido está presente en todas las acciones pero, sobre todo, en la Acción Social: "los estratos superiores del sentido, las estructuras más complejas, dependen de la objetivación del sentido subjetivo en la Acción Social" (Berger y Luckman, 1997). Así, la tipificación, la clasificación, los patrones experienciales y los esquemas de acción social constituyen los acervos colectivos del conocimiento (sentidos compartidos por un colectivo social en un momento histórico dado). Los acervos colectivos son tomados en buena medida de los acervos sociales de conocimiento (sentidos institucionalizados en el orden social más general).

Además del sentido del acto y de la acción, el orden social estructura los roles sociales así como las expectativas que existen sobre ellos (Goffman, 2010). Así, si camino por una calle oscura y sé que en esa circunstancia pueden robarme, cuando veo a otro sentado en la esquina, le asigno el rol de delincuente. 
Lo que llamamos universo simbólico estructurado y estructurante del orden social no es otra cosa que la cultura. Para Raymond Williams, la cultura es un proceso social por él que "las comunidades de distinto tipo otorgan valor a ciertos significados que se convierten en principios activos u operantes con capacidad de ordenar lo social" (Williams, 1976). En sentido análogo, pero de este lado del Atlántico, para Barbero (1987) la cultura es el lugar en el que se produce y circula el sentido a través de diversas prácticas sociales. Entonces, definimos cultura como el territorio en y por el que existe la comunicación social. En este sentido, los significados compartidos son inseparables, en tanto dimensiones significantes, de las prácticas sociales. Se trata de un conjunto de sentidos valorados a partir del que un orden social se comunica, se reproduce, se experimenta y se transforma.

Aquí resulta necesaria otra noción de Bourdieu: las significaciones sociales, que determinan el habitus y están en relación directa con la producción y reproducción de sentidos (Bourdieu, 2003). Estos patrones, construidos socialmente, rigen la vida social (el concepto está relacionado con el de acervos sociales de conocimiento y de sentido) y están sometidos, siempre, a la posibilidad de rupturas y transformaciones. Como lo señalamos hace unas líneas, la noción de habitus ampliada con el concepto de Collegium Logicum (Samaja, 2005) expresa en sentido más primario la vida en la Polis. Es decir, la pertenencia semiótica a una comunidad reglada simbólicamente implica una determinada lógica de acción. Tanto el Collegium Logicum como el habitus son dimensiones históricas y colectivas que nos determinan 
al momento de producir significados: delimitan la producción cultural de una comunidad específica en un momento dado y en un espacio concreto.

¿Cuáles son las características de las prácticas inherentes a la producción cultural? Williams señala que algunas prácticas sociales responden a necesidades concretas, como la construcción de viviendas, rutas y caminos: obedecen a la necesidad de habitar la tierra, comerciar y trasladarse. Estas prácticas tienen una dimensión significante que puede ser estudiada para conocer aspectos de una cultura. Pero también existen prácticas que no responden a necesidades materiales, como la música; Williams las llama "prácticas específicamente significantes". Según Mata, podemos pensarlas como respuesta a la necesidad humana de comunicarse y, por eso, denominarlas alternativamente como prácticas específicamente significantes o prácticas comunicacionales. Consecuentemente, todas las prácticas tienen una dimensión significante o comunicacional, aquí nos ocuparemos especialmente de las prácticas relacionadas con la producción, la circulación y el uso de la ciudad (los modos de habitar).

Los humanos como las cosas ocupan espacio. Según explica Pierre Bourdieu, el espacio físico habitado, o apropiado, se define por la exclusión mutua y constituye una yuxtaposición de posiciones sociales. Ocurre "una especie de simbolización espontánea" por la que el espacio social se traduce en el espacio físico y éste se retraduce en el espacio social, generando un "efecto de naturalización" de las jerarquías y las distancias sociales. El espacio social entonces se objetiviza y se reifica en el espacio físico; así el "hábitat 
contribuye a formar el hábitus" (Bourdieu, 2007). Las estructuras sociales naturalizadas en el espacio físico muestran que el espacio es uno de los lugares desde los que se afirma y se ejerce el poder, y es a la vez una de las mediaciones más sutiles a través de las cuales las estructuras sociales se convierten en estructuras mentales. Por ejemplo, el modelo de barrio cerrado funciona como un mecanismo de exclusión activa de indeseables mientras permite a los incluidos consagrarse simbólicamente y participar capital social acumulado por todos los residentes. Por el contrario, el barrio estigmatizado degrada simbólicamente a quienes lo habitan (Bordieu, 2007).

Desde las ciencias sociales, se hicieron grandes aportes a la reflexión de los procesos de marginalización social. La corriente que profundizó estos procesos desde el punto de vista relacional -lo que introduce además los puntos de encuentro con la comunicación social- fue el interaccionismo simbólico. Con George H. Mead y Herbert Blumer como principales iniciadores, esta corriente establece la noción de sociedad como interacción, en la que se desarrollan paralelamente la personalidad individual y la realidad social (Mead, 1972). Desde esta perspectiva, existe una continua recreación de las estructuras por la acción de los sujetos y un grupo humano que se define sólo como proceso social en curso, en el que la gente 
se compromete a ajustar recíprocamente sus conductas para tratar con la situación. Las normas y los comportamientos tienen un gran dinamismo y son negociados constantemente entre los participantes de manera implícita o explícita Blumer (1969). El ejemplo más claro de esto es la práctica del incesto y la valoración social que ha tenido en las distintas culturas y momentos históricos.

Aunque el interaccionismo no hace foco en la cuestión del poder y la dominación, constituye un aporte muy importante: comienza a pensar la marginalización como proceso social dinámico y no como consecuencia de los actos o atributos individuales de criminales y enfermos mentales. Es decir, desnaturaliza las prácticas de exclusión. En esta línea, dos trabajos se convirtieron en referencia obligada en el tema que analiza esta tesis: Estigma, la identidad deteriorada de Erving Goffman y Outsiders, de Howard Becker.

En su investigación sobre el estigma, Goffman, estudia prioritariamente el proceso por el que los sujetos y grupos sociales estigmatizados construyen su identidad en interacción con la sociedad. Goffman clasifica tres tipos de estigmas: "...En primer lugar, las abominaciones del cuerpo (...). Luego los defectos de carácter del individuo que se perciben como falta de voluntad, pasiones tiránicas o antinaturales, creencias rígidas y falsas, deshonestidad (..). Por último, existen los estigmas tribales de la raza, la nación y religión..." Podemos actualizar estas categorías estableciendo la distinción entre estigma por condiciones físicas, psicológicas y socioculturales. 
En Estigma. La identidad deteriorada, aún cuando el trabajo de campo se realiza básicamente con sujetos que son estigmatizados a raíz de sus atributos físicos, también se hace referencia a casos de estigma sociocultural (prostitutas, homosexuales, usuarios de drogas, ex presidiarios, entre otros). Goffman encuentra categorías de gran aplicabilidad y riqueza teórica para definir estos procesos como la diferencia entre "desacreditados" y "desacreditables" y sus estrategias de adaptación: mientras los desacreditables pueden manejar la información que comunican en sus interacciones sociales, los desacreditados sólo pueden manejar la tensión mediante el "ocultamiento" y el "enmascaramiento" del estigma (Goffman, 2010).

Uno de los relatos recabados en las entrevistas en profundidad, puede dar cuenta de la articulación práctica de estos conceptos de Goffman: Susana comentaba que muchas veces sufrió la discriminaron en la búsqueda de trabajo por vivir en villa; pero su esposo Cacho - que además de vivir desde niño en Isla Maciel estuvo privado de su libertad en varias ocasionesdespués de relatarme sus penurias para conseguir trabajo al salir de la cárcel por última vez, me contó sobre una oportunidad en la que fue a buscar empleo a una panadería del barrio de Chacarita: "nunca había ido para esa parte (de la ciudad), tardé un montón, tomé dos colectivos porque el subte no me gusta, no estoy acostumbrado, me perdí por ahí atrás del cementerio (...) Encima me tuve que poner una camiseta de manga larga para que no se me vean los tatuajes, porque si no me sacan la ficha de tumbero (presidiario) al toque, y hacía un calor de morirse. Así que llegué tarde y todo chivado (transpirado) y cuando me vieron me 
dijeron que ya habían tomado a otro. Ni me llegaron a discriminar por vivir acá, no me dieron tiempo a discriminarme por villero, jaja...".

El caso de Cacho es ilustrativo sobre cómo actúa la trama de la estigmatización; él sabe que puede ser estigmatizado por vivir en una villa pero el estigma social más fuerte para él es haber estado preso, por eso intentó enmascararlo (en términos de Goffman) cubriendo los tatuajes que se hizo en prisión. Por otro lado, la estigmatización territorial que sufre Cacho es uno de los procesos más sutiles ya ni siquiera hizo falta que dijera dónde vive, el sólo hecho de no haber tenido nunca acceso a otras zonas de la ciudad (el barrio de chacarita y el subte como transporte al que "no está acostumbrado" lo vuelve de por sí material etiquetable: llegó tarde y sucio. Sobre este punto, se puede agregar al concepto de enmascaramiento de Goffman que la capacidad del desacreditado de ocultar o enmascarar su estigma está siempre limitada por el contexto y por la interacción en la que, habitualmente, el poder está del lado de los "normales" y no del desacreditado. Este ejemplo muestra también que no sólo "enmascaramiento", "ocultamiento", "desacreditado" y "desacreditable", sino también "estigmatizado" y "normal", son categorías móviles que se definen en el proceso de comunicación, ya que el empleado de la panadería de Chacarita que actuó como sujeto normal estigmatizador, es también material etiquetable y puede ser el estigmatizado en otras situaciones y en interacción con otros sujetos.

No obstante, para estudiar los procesos de marginalización territorial, el aporte fundamental es la tesis de que el estigma no se origina en el atributo, siquiera en la 
conducta individual de la persona, sino en la interacción social entre "estigmatizados" y "normales" (Goffman, 2010). Desde ahí parte el problema de investigación que se formula el psicólogo social, desde "el retorno (al tema) de la consideración mutua, que la psicología social de Mead nos enseña cómo iniciar pero no cómo terminar" (Goffman, 1979) .

También en La presentación de la persona en la vida cotidiana (publicado originalmente en 1963, el mismo año que Estigma...) Goffman aporta categorías interpretativas muy ricas para estudiar los procesos de marginalización. Allí, define al mundo social como drama en el que las acciones son "actuaciones", puestas en escena. Esas actuaciones se desarrollan en un espacio, físico y simbólico, un escenario que sirve de marco. Goffman diferencia entre distintas "regiones" del escenario que suponen distintas expectativas de rol de los actuantes: las regiones habilitan algunas acciones y sujetos y deshabilitan otras, que por quedar desubicadas se etiquetan como desacreditables. Hay una diferencia entre la "región posterior", el frente del escenario o "front stage" y la región anterior, detrás de la escena - "back stage". Así, cuando asistimos a un acto patrio en una escuela, se espera que los niños y niñas que actuarán se cambien detrás y no delante del escenario; se espera una cierta conducta (o rol) de la Directora al presentar la ocasión y se espera que padres y madres se comporten como espectadores del acto. Si alguno de los actuantes tuviera una actitud contraria o muy distinta a las que hemos señalado (si los niños se desvistieran en el escenario, la Directora bailara y cantara en vez de realizar la presentación correspondiente - los padres y madres dieran la espalda a la presentación y comenzaran a organizar un partido 
de fútbol) tales conductas serían identificadas rápidamente como desacreditables por parte del resto del auditorio.

Pero pensemos estas nociones en el contexto de los procesos de estigmatización de tipo sociocultural vinculados a los territorios urbanos y a la asignación de sentido sobre la otredad: En una oportunidad, una vecina del barrio Isla Maciel me mostró fotos de su hermano junto a dos amigos, todos vestidos con traje y corbata. En las fotos se los veía sonrientes y, por eso y por el atuendo poco común en el barrio, supuse que la foto había sido tomada en alguna ocasión especial (un casamiento o un bautismo). La vecina me explicó que no, que su hermano y amigos se vestían con traje y corbata para ir a trabajar a Puerto Madero -el trabajo consiste en realizar lo que se llama "la inteligencia" de un robo-. Así, la foto es una muestra del back stage de una actuación determinada, que sólo conocen quienes están al tanto de las particularidades de esa puesta en escena. La vecina me explicó que ellos saben perfectamente que ni su imagen ni su atuendo logran que los confundan con jóvenes ejecutivos de las multinacionales ni con estudiantes de la Universidad Católica; pero así vestidos, los policías suponen que son vendedores de perfumes o de relojes y los dejan caminar y observar tranquilos: "si van a Puerto Madero vestidos de pibes chorros no duran ni cinco minutos antes de que los levante la policía".

Es decir, para los otros(los normales) el traje cumple la función de enmascaramiento del estigma. Pero, como veremos más adelante, la estigmatización sociocultural es una construcción compleja que se vincula fuertemente con la identidad, por eso los estigmatizados 
que indagamos no siempre quieren ocultar socialmente su material estigmatizable, esto depende del contexto de la situación comunicacional (del escenario de la interacción, de los otros actuantes y del sentido de la puesta en escena). Pensemos, por ejemplo, en los tatuajes de Cacho que, mientras en ciertos contextos actúan como evidencia del estigma (denotan que estuvo preso) en otros como la cárcel o la villa, adquieren nuevos sentidos identitarios vinculados a la pertenencia, el honor y la respetabilidad.

Decíamos que otra obra fundamental para pensar este tipo de procesos es Outsiders (1963). Se trata de una investigación etnográfica con músicos de jazz y usuarios de marihuana, lo interesante de este recorte es que analiza grupos de estigmatizados (como los músicos de jazz en el contexto de los años 50 en las ciudades de Estados Unidos) que no pueden identificarse como delincuentes ni como enfermos mentales, por lo que el estudio de la "desviación" adquiere nuevos matices y refiere a tramas socioculturales más complejas.

En este estudio, Becker pone el foco en la noción de redes colaborativas, lo que le valió el calificativo del "anti-Bourdieu" estadounidense -como él mismo lo refiere en Becker y Pessin, 2006- ya que donde el sociólogo francés ve mediaciones ideológicas, procesos de dominación y acumulación de capital, el autor de Outsiders ve redes colaborativas que configuran los procesos de socialización.

Becker sostiene que los grupos de estigmatizados no son homogéneos y no necesariamente comparten factores comunes de personalidad o de experiencias de vida, lo que de alguna manera desdibuja la aplicación de la teoría para comprender procesos como los que sufren los 
habitantes de territorios marginalizados. No obstante más allá de la diferencia de enfoques, la teoría del etiquetamiento, acuñada por Becker, no deja de develar las tensiones vinculadas al poder que suponen que algunos colectivos sociales establecen las normas y los parámetros generales que regulan los mecanismos de inclusión y exclusión social.

El sociólogo estadounidense coincide con Goffman en que la desviación no es una cualidad del acto (o del atributo individual) sino una consecuencia de la aplicación de reglas y sanciones por parte de terceros: "los grupos sociales crean la desviación al establecer las normas cuya infracción constituye una desviación y al aplicar esas normas a personas en particular y etiquetarlas como marginales" (Becker, 2009). Así establece que la desviación es una construcción social, que hay una empresa moral que hace las reglas y que las ciencias sociales tienden a obviar el estudio de estos fabricantes de normas para poner la lupa sobre las personas a quienes se les aplica la etiqueta que las deja fuera, los outsiders.

La rotulación del outsider coloca a la persona en un estatus de "anormalidad" que condiciona la totalidad de su vida social y lo obliga a socializarse en el marco de "una carrera" conforme a la etiqueta que se le adosó. Aunque la noción de "carrera" ha sido debatida, y volveremos sobre ella más adelante, lo que se pone de manifiesto es el arbitrario reparto de las etiquetas que permite desentrañar no ya las penurias de los subordinados o subalternos, sino los mecanismos por los que los grupos hegemónicos (que deciden entre otras pautas, criterios de convivencia ciudadana así como legislación penal) orientan la selección de las personas a marginalizar. 
$\mathrm{Ni}$ Bécker ni la teoría del etiquetamiento promueven posturas relativistas del orden social, como eliminar las cárceles o legalizar los asesinatos y violaciones, por supuesto que hay etiquetas que se colocan en material más etiquetable que otro: "sin duda que en el caso de los asesinos seriales hay mucho material bien etiquetable, así como que en los fumadores de marihuana hay poco y en los homosexuales no hay nada, pero lo cierto es que eso no interesa al etiquetamiento, que lo hace en unos pocos casos y de modo arbitrario, pues no siempre se etiqueta como homicidas a los que matan: sin detenerme en las ejecuciones sin proceso, (...) en los asesinatos masivos genocidas y en otros horribles crímenes impunes, lo cierto es que tampoco se etiqueta como homicidio la guerra, las muertes por polución ambiental, las penas de muerte por error, el cierre de hospitales, de puestos sanitarios, la desidia en el cuidado de las rutas..." (Zaffaroni, 2011).

Para cerrar esta mención a los aportes del interaccionismo simbólico sobre la relación entre desviación, etiquetamiento, estereotipos y estigmatización, es pertinente mencionar a Denis Chapman y su libro Sociología y estereotipo del criminal (1968), en el que desarrolla cómo se criminaliza de acuerdo a estereotipos que son creados como síntesis de los peores prejuicios de una sociedad y que no responden sólo a cuestiones de clase ni de capacidad económica (Zaffaroni, 2011).

Luego, en términos generales, los urbanistas que trabajaron desde el interaccionismo y, sobre todo, los de la Escuela de Palo Alto (de la que Chicago funcionaba como centro de estudios urbanos), estudiaban a la comunidad desde la noción de comunidad biótica, con 
métodos muy distintos a los de los antropólogos culturales y a los de la sociología estructural-funcionalista. Sin embargo, tienen importancia los conceptos de organización y desorganización social planteados en esta línea.

Los urbanistas de la Escuela de Chicago se interesaron profundamente por las relaciones entre la estructura física y la espacial de la ciudad y el "orden moral" surgido de ella, para poner de manifiesto las correlaciones entre una determinada área natural y los fenómenos de desorganización social que ocurren en ella. Uno de los mayores exponentes de esta perspectiva es Robert Park, que habla de ecología urbana como el estudio de las relaciones de los sujetos entre sí y con el ambiente, en su tesis, el territorio es una parte fundamental de la ecología. Park acentúa la importancia de lo que llama "regiones morales" de una ciudad, con ello se refiere a aquellas zonas en las que están alterados o inhibidos determinados impulsos naturales y relajados algunos instintos -por ejemplo las denominadas zonas rojas o rozas-, con un aumento de la probabilidad de aparición frecuente de conductas no conformistas y desviaciones sociales manifiestas (Park, 1999). 


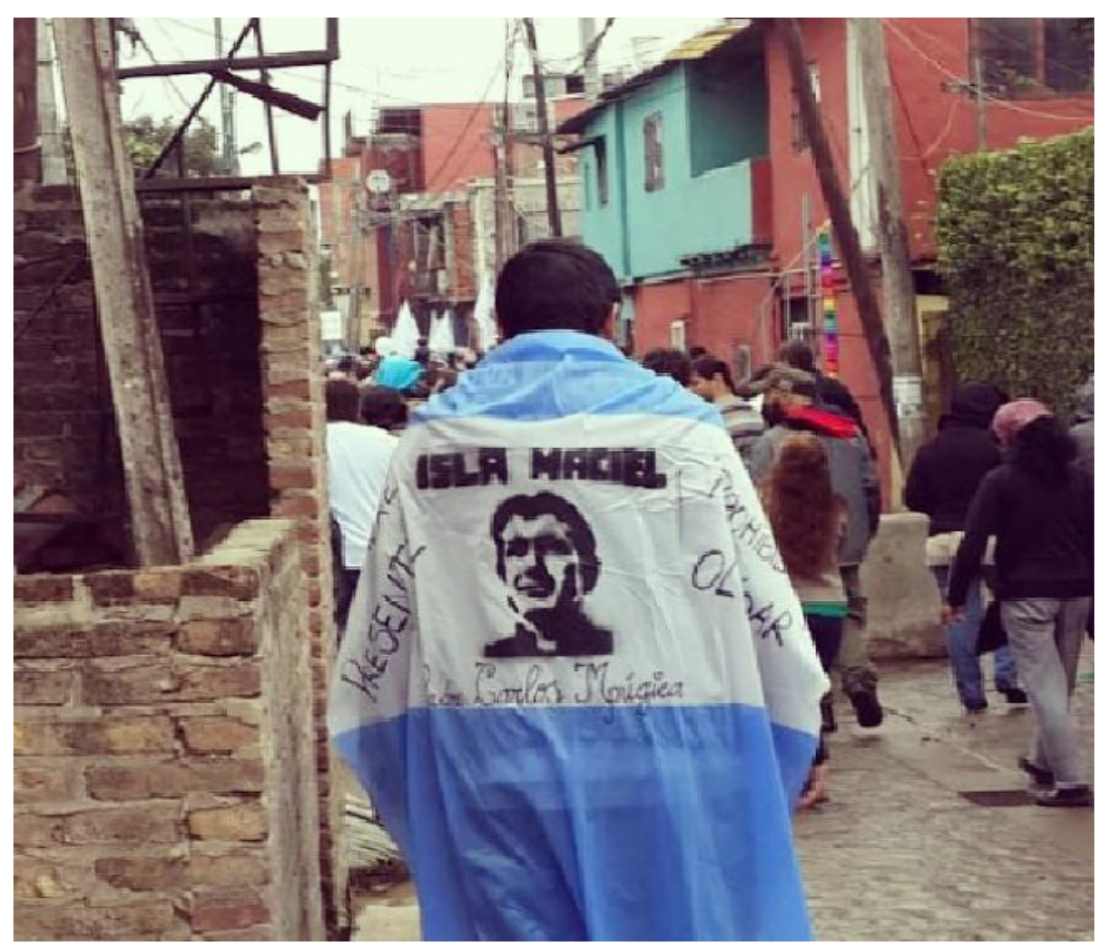

$\star \star \star$

Volviendo a la desviación en términos de marginalización y pobreza, en América Latina fue muy extendido el enfoque-vinculado a la teoría de la modernidad- que analiza la marginalidad como la resultante de los procesos de industrialización y de las etapas llamadas 
"tradicionales" y "modernas". En un primer momento, el planteo era que la sociedad moderna había llegado tardíamente a algunos continentes y, por tanto, América Latina estaba en un proceso de modernización en el que convivían sectores "modernos" -desarrollados, incluidoscon sectores "tradicionales" - atrasados, excluidos-. Así, los "atrasados" irían ascendiendo - mejorando en la medida en que la sociedad "moderna" fuera avanzando mediante la difusión de valores y patrones culturales. Si bien esta concepción es claramente etnocéntrica y sociocéntrica, su mayor aporte fue identificar a la marginalidad social como resultado de la segregación producida por el proceso de industrialización. Desde esta perspectiva, el desajuste sería corregido con la incorporación paulatina de los pobres a los procesos de industrialización (Banco Mundial, 1990).

Para entender estos conceptos, es necesario tener en cuenta su contexto de producción: se trata de una época en la que la organización geopolítica se leía en términos de sociedades y países desarrollados y subdesarrollados, y los rasgos culturales populares, asociados a territorios y sectores sociales "marginales" (latinoamericanos, asiáticos y africanos). Así, la cultura popular de los países periféricos era considerada negativa en tanto impedía el desarrollo de la cultura "moderna" (presente en Europa y en Estados Unidos). Estas trabas culturales debían ser superadas, modificando los patrones de conducta desviados, con el fin de promover el desarrollo a la esperada modernidad (Germani, 1973).

Las nociones que explican el fenómeno de la marginalidad como producto de la acumulación capitalista y la generación de población excedente, en un contexto de desarrollo desigual 
(Amin, 1973), tuvieron su devenir en los países periféricos. En América Latina una de las derivaciones más importantes de esta línea fue la Teoría de la Dependencia y del "dualismo estructural" (Nun, 1970). Desde allí, la marginalidad es, en el marco del capitalismo periférico, el producto de relaciones sociales capitalistas y de la lógica de producción de una superpoblación relativa. Esta superpoblación no constituye un "ejército industrial de reserva", sino un sobrante (Argumedo, 2004), un sector no productivo, denominado "masa marginal" o "polo marginal", que no está integrado en el mercado formal del trabajo (Quijano, 1971).

Las teorías de la desviación también fueron estudiadas desde las ciencias sociales latinoamericanas, más allá de los desarrollos realizados por las perspectivas médica y criminológica. Uno de los autores más notables en el análisis de la "desviación" y los "desviados" es el antropólogo brasileño Gilberto Velho, considerado fundador de la antropología urbana en Brasil. Velho retoma la perspectiva interaccionista para analizar las características de la desviación en el contexto de las relaciones comunitarias que se imprimen en la ciudad. El trabajo más ilustrativo en este sentido es la investigación Desvío y Divergencia. Una crítica de la patología social (1978), que escribe en el marco del trabajo realizado durante una estancia de posgrado en la Universidad de Austin Texas, justamente en colaboración con Bécker. 
Como veremos en el siguiente capítulo al reflexionar sobre los aportes del Poscolonialismo y el Culturalismo latinoamericano, muchos de los autores que investigaron los procesos de exclusión social lo hicieron desde la diáspora, aunque lograron construir posiciones epistemológica y políticamente periféricas, con respecto al centro del pensamiento académico institucionalizado. Tal es el caso de Norbert Elías, uno de los más influyentes de la segunda mitad del siglo XX en la teoría sociológica sobre marginalización y construcciones de la otredad, su texto más esclarecedor en esta línea es Los establecidos y los outsiders -en algunas ediciones traducido como Los establecidos y los forasteros-.

Así como Goffman y Bécker son figuras destacables para cualquier estado de la cuestión de los procesos de marginalización territorial, también lo es Elías; no sólo por sus aportes conceptuales sino también por su propia trayectoria como intelectual. A pesar de que Elías había publicado El proceso de civilización (su primera obra importante) en 1939, era un desconocido en los círculos académicos occidentales cuando en 1965 dio a conocer Los establecidos y los outsiders. Esta investigación fue el resultado de un estudio sobre relaciones comunitarias, llevado adelante entre 1958 y 1960 en una pequeña localidad de los 
suburbios de Londres, en colaboración con John L. Scotson (maestro local y alumno de postgrado) .

Es decir, la figura de Elías muestra la paradoja de muchos intelectuales periféricos que produjeron conocimiento sobre pero también desde los procesos inclusión / exclusión que vinculan cultura y territorio. En primer término, Elías era un judío alemán y como tal, en la Alemania nazi y frente a la inminencia de la Segunda Guerra Mundial, eligió el exilio antes que la muerte. A partir de allí anduvo por varios países en busca de una plaza en alguna Universidad, y pasó dos años en Ghana como profesor de Sociología, poco antes de jubilarse. Esto lo llevó a preocuparse más por la supervivencia y la vida cotidiana que por mantener la productividad científica, por lo que se fue alejando cada vez más del establishment académico de la sociología occidental.

Así, a contramano de la tendencia de su tiempo -que apoyaba el proceso de institucionalización en la cientificidad disciplinar de la sociología-, Elías propuso un abordaje epistemológico que entrelaza sociología, historia y psicología, influido explícitamente por el pensamiento de Marx y Freud y probablemente por la Escuela de Frankfurt (Casquete, 2003). También en este sentido de búsqueda y necesidad transdisciplinaria retomamos a Elías.

El concepto de "extraño" fue abordado por otros autores como Simmel y Schütz pero más vinculado a la acepción de extranjero o forastero en relación con una comunidad, Elías aporta una diferenciación ya que vincula directamente su concepto de outsiders a la propagación de 
los procesos de estigmatización y exclusión, y se basa en el estudio de las configuraciones sociales en los que se originan. El outsider puede ser el sujeto (individuo para Elías) o el grupo y puede serlo por dos motivos: El primero refiere a la opción de un sujeto o grupo de vivir de forma diferente al estilo de vida comúnmente aceptado, es decir el outsider que construye de forma afirmativa su propia identidad y camino de vida (como los menonitas o los veganos) y en el segundo caso se trata del sujeto o grupo que no es familiar, el que viene de fuera, que no es capaz o no está preparado para ser parte de la sociedad establecida. En este caso, el más asimilable al problema de investigación que nos ocupa, plantea cómo los juicios morales y de valor que están relacionados a la figura del outsider son determinados por el establishment, que jerarquiza y juzga la capacidad para ser considerado miembro, o no, del grupo más poderoso (Elías, 2000).

Es decir, no se detiene en el análisis de la figura del diferente sino que analiza las relaciones de poder entre los grupos ya establecido y los outsiders, que generan la discriminación hacia estos últimos.

De igual modo, Elias plantea que la clave de la exclusión no es la etnia (como atributo objetivo de distinción) sino la acción del grupo dominante para establecer jerarquizaciones sociales y las interacciones dialécticas por medio de las cuales se dan estos procesos. Así, no estudia al outsider en sí, sus problemas de adaptación, las consecuencias y características de su situación de excluido, ni a la sociedad establecida y sus representaciones de la marginalidad; sino que trata de comprender los procesos de interacción 
mutua que posibilitan la estigmatización. De ahí, concluye que las funciones y configuraciones que se establecen muchas veces son ajenas a las voluntades de los sujetos y por lo tanto propone las alteraciones "promovidas por la acción consciente de los individuos" como estrategia de maduración de las formas de relacionamiento social (Ribeiro, 2009). Si los outsiders son aquí aquellos miembros de un grupo que de formas más o menos violentas sufren estigmatización y son excluidos de los procesos de toma de decisiones de la vida comunitaria, una acción comunitaria deliberada podría contrarrestar la naturalización de la exclusión promovida por el grupo hegemónico. Hay en esta tesis una voluntad de intervención en la realidad si se analiza desde la investigación para la transformación social; en ese sentido el pensamiento de Elías es fundamental para cualquier trabajo de investigación que se proponga aportar al diseño de políticas sociales.

Los problemas vividos por los outsiders que analiza Elías, se relacionan en gran medida a la discriminación étnica y su actualización se vincularía más directamente con el estudio de los procesos migratorios, cada vez más comunes en el mundo contemporáneo. Las situaciones de encuentro estimuladas por las migraciones generan, especialmente en Europa, configuraciones socioculturales caracterizadas por prejuicios que tienden a la estigmatización y a la exclusión social: "Procesos de esta naturaleza sucedieron y continuarán sucediendo en muchas comunidades del mundo todo. Vez por otra, en el contexto del desarrollo cada vez más rápido de los países y de las tensiones, sublevaciones y conflictos suscitados por él, grupos de personas abandonan sema voluntariamente su tierra natal en la búsqueda del ganapán, 
impulsadas por decisiones gubernamentales o, quizá, por la fuerza de las armas, y van a instalarse en otros lugares, a menudo a puerta de grupos más antiguos o en el seno de ellos" (Elías, 2000).

Pero aunque Elías no hace foco en las diferencias étnicas, estas tienen la cualidad de diferenciar tajantemente a los grupos distintos que convivan en un mismo espacio, y eso hace más claras las evaluaciones mutuas. En ese contexto de análisis se configuran dos procesos: la valoración subjetiva y mutua entre ambos grupos, y la emergencia de sentimientos de rivalidad. Las circunstancias de contacto son percibidas, sobre todo, como circunstancias de competencia y no como situaciones que merezcan un tratamiento diferenciado y direccionado hacia medidas concretas de inclusión social (Ribeiro, 2009). Pero en el caso que nos ocupa el análisis de los procesos de estigmatización territorial en función del diseño de políticas habitacionales populares- los límites entre los grupos son más difusos; los discriminados pueden convertirse en discriminadores, de acuerdo al contexto comunicacional o, en palabras de Goffman, al escenario en el que se producen las interacciones y a las determinaciones que éste puede suscitar sobre las expectativas de rol de los actuantes. 
Otro aporte, en este caso más reciente, al estudio de la marginalización desde la sociología de la desviación, lo hace Philippe Bourgois con su texto En busca de respeto. Vendiendo crack en Harlem. En esta investigación, que fue publicada por primera vez en 2003 , Bourgois analiza una experiencia etnográfica que realizó a mediados de los 80 , cuando se mudó por tres años al gueto latino de Nueva York. Allí, con el objetivo de desentrañar el funcionamiento de los circuitos de la economía ilegal, convivió cotidianamente con un grupo de jíbaros (portorriqueños nacidos en Estados Unidos) que formaban parte del negocio de la venta de crack.

Además de ciertos aspectos de la perspectiva metodológica que retomaremos oportunamente, es muy interesante el concept de Bougois de "cultura callejera en la inner city". Si bien los términos que constituyen la categoría son conceptualmente debatibles: en primer lugar, la definición de la cultura de la calle como una otra cultura -autónoma, por ejemplo, de las definiciones de cultura popular-, y el término de inner city, que como dice el propio Bourgois no es más que un eufemismo para referirse al gueto. Lo central de esta categoría es la descripción de que las comunidades marginalizadas desarrollan rasgos culturales, que emergen como respuestas a la exclusión social de la sociedad convencional. "La cultura de la calle erige un foro alternativo donde la dignidad personal puede manifestarse de manera autónoma". Otra vez pongo en duda la noción de autonomía -sobre todo en el caso de valores y prácticas culturales de resistencia-, pero resulta válida la idea de que existen pautas culturales, modos de hacer y decir, de comunicarse y de interactuar, que no pueden pensarse 
por fuera de los procesos de exclusión social. Así la identidad, la pertenencia, el honor, la dignidad, son roles, significan para el sujeto también en función de lo que significan para su entorno social.

En el mismo sentido que con Norbert Elías, entiendo que uno de los aspectos más significativos para esta investigación que hace En busca de respeto está en sus conclusiones, ahí el investigador sitúa el caso en su contextos (histórico, social, político, económico y cultural) y ensaya cuál debería ser el rol del Estado, por medio de la intervención activa a través de políticas sociales. Así, el autor afirma que hasta el momento (última década del siglo pasado) las políticas contra la pobreza y el abuso de narcóticos en Estados Unidos han pecado de ingenuidad y/o de un idealismo absurdo. Ya que la segregación social depende de una telaraña de "fuerzas estructurales, legados históricos e imperativos culturales" que evidencian, por un lado, que la imposibilidad de pensar en soluciones rápidas obliga a diseñar intervenciones complejas y a largo plazo y, por otro, que es imprescindible que exista "factibilidad política" para llevar a cabo estas medidas (Bougois, 2010). La sentencia se aplica igualmente al tema de la urbanización de villas y asentamientos.

Por ejemplo, sobre el problema del narcotráfico y el abuso de drogas, señala que para él una solución rápida sería la legalización del consumo y el tráfico de estupefacientes, porque así se afectaría rápidamente la rentabilidad del negocio ilegal y se inclinaría la balanza hacia la economía formal, volviendo más complicada la explotación de personas y disminuyendo la violencia (tanto interpersonal como institucional). Pero también sostiene que medidas como 
esta sólo funcionarían en la dirección esperada en el marco de acciones a mediano y largo plazo. A mediano plazo, Bourgois estima que algunas medidas posibles para atacar la marginación son la estimulación del empleo formal, especialmente para los jóvenes de barrios marginales, el aumento de cupones de alimentos, asistencia en salud, programas de capacitación y subsidios a desocupados; todo ello acompañado de una reforma fiscal y una redistribución de la inversión estatal. A la vez que explica que en el largo plazo debe procurarse la desburocratización del acceso a la protección estatal por parte de las clases populares y la incorporación progresiva de los pobres al mercado de trabajo formal. No obstante, en el contexto del análisis de Bourgois, los post-noventa en Estados Unidos, no existía la factibilidad política que habilite pensar en el abordaje a largo plazo del problema de la pobreza y la marginalización y él así lo aclara. Por otro lado, explica también que es necesario que el Estado reconozca que su intervención se da en el marco de una compleja trama cultural que es necesario transformar para cambiar el sentido común "que tiende a culpar a las víctimas de su fracaso".

En Argentina, estos procesos se dan de manera diferente. Como desarrolla Daniel Míguez: (en nuestro país) "la experiencia social de los que hoy son conocidos como 'pibes chorros" fue constituyéndose a partir de los procesos de pauperización y marginación que se desarrollaron en las sucesivas generaciones a partir de los años 80" Míguez (2010). Desde allí el sector formal del trabajo dejó de crecer y de incorporar paulatinamente a los jóvenes, la mayor parte del empleo producido se creó en el sector de la economía informal. 
Esa situación no hizo sino profundizarse durante los 90 y es recién hacia 2006 que comienza a revertirse.

El universo de estudio que analiza Bourgois se diferencia del de esta investigación no sólo en términos del contexto de oportunidades políticas y de intervención del Estado para la inclusión social, sino también porque en los barrios marginalizados del AMBA hay diferencias importantes respecto a lo que ocurre en el gueto estadounidense en torno a la etnicidad como elemento central de la desigualdad social: mientras que allí la discriminación racial se remonta a la guerra de secesión (1861-1865) y es la característica principal del proceso de diferenciación y segregación social, aquí los límites de los sectores populares son más lábiles e incluyen a amplios sectores de la clase media y media baja que en los momentos de crisis económica y desocupación cayeron debajo de la línea de pobreza.

Hasta mediados de la década del 70, en Argentina los números de la pobreza estructural eran casi nulos y la mayoría de quienes estaban en condición de pobreza eran los denominados pobres transicionales. Por otro lado, cuestiones históricas -como el acceso a los sistemas de educación y salud pública y gratuita y la experiencia de la incorporación masiva de los sectores populares a la clase trabajadora durante los gobiernos peronistas- actúan de manera diferencial en la trama sociocultural popular argentina y en la configuración simbólica de la otredad.

Con esto no se está afirmando en absoluto que no exista discriminación étnica en nuestro país o que ésta no se reproduzca en los territorios urbanos marginalizados, sólo se quiere 
poner de relieve que en la historia de la conformación de las clases populares del AMBA Y especialmente en el primer cordón del Conurbano, la etnia no es un factor que venga necesariamente ligado a la pobreza. Dicho de otra forma, tanto los pobres que vivían en los conventillos durante los primeros años del siglo XX, como gran parte de los habitantes de los barrios pobres en la actualidad, así como los llamados cabecitas negras llegados a Buenos Aires en las décadas del 40 y 50, han logrado mayores o menores grados de ascenso social que los ubicaron, en distintos períodos históricos y de acuerdo a los vaivenes de la economía, dentro del arco de las clases medias urbanas, sin perder por eso su condición de sectores populares. 


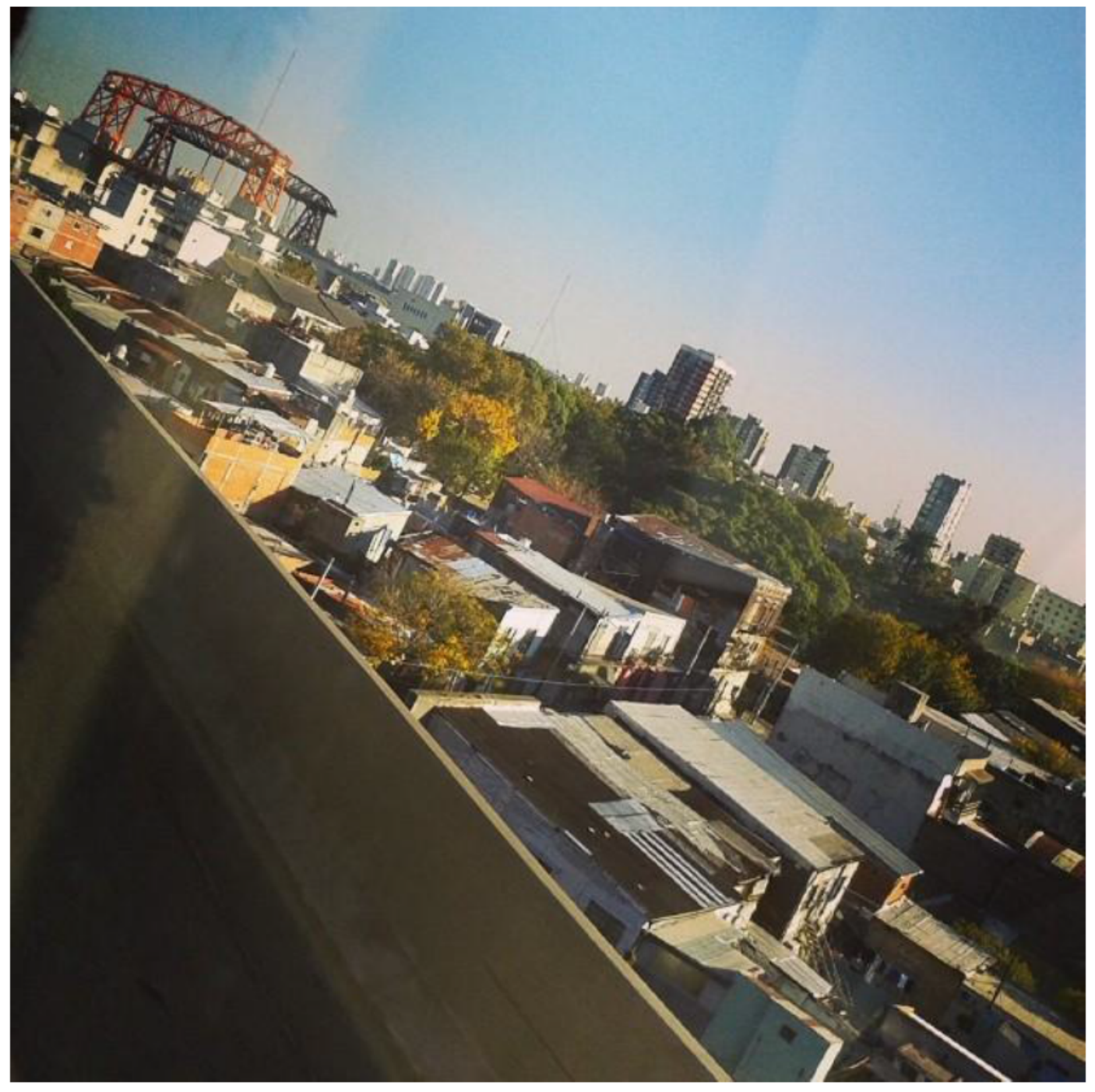

CAPITULO II 
En este capítulo se propone un recorrido por los desarrollos que, desde las ciencias sociales y los estudios de cultura y comunicación, se han realizado en torno a lo popular y lo urbano, y algunas nociones específicas que aportan al universo teórico de esta tesis como subalternización, metropolización, ciudad global y ciudad multicultural, nueva marginalidad urbana, entre otras.

Según Roger Chartier (1994), el debate sobre la cultura popular puede sintetizarse en dos grandes enfoques. El primero, vinculado a la línea antropológica -y distante del etnocentrismo- definió a la cultura popular como un ente autárquico, cerrado en sí mismo y con características propias. El segundo, más relacionado con la teoría y la crítica de arte, la definió en relación con la cultura hegemónica a través de comparaciones entre productos culturales (que gozan de la legitimidad de las clases dominantes, aquella de la que carece la cultura popular). Esta segunda línea es la más antigua, comienza a principios del siglo XIX con los Románticos y los folkloristas -aún antes de que las ciencias sociales incorporaran el concepto de cultura popular- pero se mantuvieron, según Renato Ortiz, como una "ciencia mediana", enredados entre la recopilación y la voluntad de reconstruir las épicas nacionales (Ortiz, 1989).

También en Argentina el estudio de la cultura popular está asociado al análisis, la crítica y en muchos casos la producción de arte (el circo criollo, el sainete y el tango fueron los primeros géneros mestizos) y especialmente literaria (la Gauchesca, las historias de los Guapos del 900, etc.). Luego, la línea seguida por el grupo de Aníbal Ford, Jorge 
Rivera y Eduardo Romano, intelectuales formados en la literatura e identificados con la causa del movimiento inclusivo del peronismo, también construye una especie de contracultura cuando propone linajes y bienes culturales alternativos (Vidarte Asorey, 2008). En particular, Ford y Romano, trabajan la apertura del repertorio de bienes legítimos hacia formas culturales que desbordan lo literario, como la cultura de la oralidad y de la imagen. Trabajan los tangos, programas de radios, películas, guiones de cine, tiras cómicas, que pasan a conformar parte de los bienes de la cultura nacional y popular. Sobre este tipo de análisis, es interesante lo que Aníbal Ford señalaba en sus clases en el marco de la experiencia de Universidad Nacional: "(el lenguaje) es influido en sus formas de organización por los demás sistemas mencionados (económicos, sociales, políticos, de ideas, de conductas) y a su vez, influye nuestra manera de interpretar la realidad" (Ford, 2004). En el mismo sentido, recomienda a sus alumnos estudiantes de historia que tomen en cuenta que "trabajar sobre un texto literario (implica entender) no sólo la pluralidad significativa de un texto cualquiera sino también su incidencia sobre la historia".

No obstante para el campo institucionalizado de las ciencias sociales, las investigaciones sobre los sectores y las culturas populares se volvieron relevantes recién durante la segunda mitad del siglo pasado. Con la ayuda del revisionismo histórico y la antropología moderna, pero especialmente a partir de la aparición de los Cultural Studies y sus derivaciones en la escuela culturalista latinoamericana y los estudios poscoloniales, se comenzó a mirar a la cultura popular a través de otros prismas. Y aun así, con la múltiple producción académica y 
científica al respecto, los estudios sobre cultura popular en los países periféricos se siguen haciendo desde espacios marginales a la Ciencia y la Academia.

Los Estudios Culturales Ingleses, constituyeron también un punto de encuentro para las teorías de comunicación y los estudios de cultura. Los Cultural studies hacen foco en la dimensión política: en la mayoría de los trabajos, la intención es desentrañar los procesos de construcción de la hegemonía. Para esta línea, cultura es el modo de vivir dentro de la sociedad industrial y engloba todos los sentidos de esta experiencia social. Así, la concepción y construcción de los sentidos sociales sólo pueden ser explicadas en función de la estructura social y de su historia.

La producción teórica más relevante en este sentido se inicia en la Escuela de Birmingham, y sus exponentes más destacados fueron Richard Hoggart, William Thompson y Raymond Williams. A diferencia de la tendencia funcionalista, dominante en la época, estos intelectuales incorporaron la clave antropológica para pensar la cultura y la comunicación. En esta escuela emergió luego una segunda generación de pensadores: la new left. Esta corriente se acercó más a la línea marxista europea de Antonio Gramsci-lo que llevó a que la cultura dejara de ser pensada como superestructural- y a la de los intelectuales de la Escuela de Frankfurt (Althusser, Adorno y Marcuse) cuya influencia incrementó la mirada crítica en los análisis.

Entre los representantes de la new left, Stuart Hall -que también trabajó en estudios poscoloniales-, Perry Anderson y Rafael Samuel continúan con los estudios comunicacionales bajo la perspectiva crítica, incluso hacia la generación anterior de birminghianos. La 
producción científica y los teóricos de ambas generaciones fundantes de los estudios culturales siguen siendo referentes clave para la construcción de conocimiento en torno a la cultura, sobre todo en América Latina. Los estudios culturales latinoamericanos que como herederos de Gramsci, pero también de Mariátegui, de Freire y de la experiencia de Mattelart durante el gobierno socialista de Salvador Allende, se preocuparon por analizar las prácticas y sentidos de resistencia contenidos en las culturas populares a partir de los análisis de recepción crítica de las audiencias, la educación no formal y las manifestaciones artísticas populares -música, literatura, radio, etc.- (Mattelart y Neveu, 2004).

También los estudios poscoloniales son herederos de los Cultural Studies. Esta corriente teórica, por su parte, emergió con la intención de reescribir la historia a partir de la experiencia cultural invisibilizada por el imperialismo colonial. De corte antiimperialista, surge entre grupos de intelectuales sudasiáticos tras el período de descolonización y reconstrucción de la historia nacional en sus países. Enfatiza la indisolubilidad de la subalternidad económica y la subalternidad cultural. Los estudios Poscoloniales se dedicaron a recuperar las identidades negadas y las voces silenciadas (Mattelart, 2003).

El Poscolonialismo como corriente surgida principalmente en la diáspora -básicamente en Inglaterra y Estados Unidos-, impregnó una pluralidad de disciplinas del mundo anglosajón, desde la historiografía a la crítica literaria, desde la antropología a los estudios culturales, desde la teoría política a los estudios de género. La publicación fundacional es la obra Orientalismo, de Edward Said (1978) y en los años siguientes, aparece un conjunto de 
textos que continúan esta línea. Uno de ellos, que se cuenta entre los más destacados es Europa y sus otros (Baker, 1985) que, por un lado, introduce la innovación teórica determinada por la el análisis crítico del discurso colonial; y, por otro, pone en debate los rasgos monolíticos que el discurso colonial tendía a adoptar en la obra de Said. Baker se concentra en los procesos de hibridación, negociación y resistencia que, desde los orígenes de la modernidad, se inscriben en la trama discursiva también a partir de la interacción cultural con los colonizados.

En un clima intelectual caracterizado por la recepción del posestructuralismo y por los avances del debate sobre el postmodernismo, la crítica postcolonial avanzó no sólo en el análisis del discurso colonial sino también a partir de las relecturas innovadoras de algunos clásicos del pensamiento anticolonial como William DuBois, Cyrill James, Eric Williams y Frantz Fanon. El camino de la teoría poscolonial fue seguido rápidamente por académicos indios (Gayatri Spivak, Homi Bhabha, Ranajit Guha), surafricanos (Benita Parry), árabes (Aijaz Ahmad) y también latinoamericanos (Stuart Hall, Juan Zeballos, Walter Mignolo, Alejandro Solomianski, entre otros). Ya en siglo XXI, desde Portugal, Boaventura de Sousa Santos adoptó y transformó el Poscolonialismo para acuñar los estudios sobre "cosmopolitanismo subalterno" en relación con las prácticas contrahegemónicas de los 
movimientos sociales que luchan contra la globalización neoliberal y sus consecuencias en términos de exclusión social (de Sousa Santos, 2002) ${ }^{1}$.

En "Notas históricas sobre la cultura popular", Renato Ortiz señala algo clave: que pensar desde la ciencia social a la cultura popular implica enfrentarse a la problemática histórica centro-periferia. Y destaca la labor de los intelectuales que ponen sobre el tapete el estudio de la cultura popular en sus territorios periféricos sin compararla con la de élite, ya que le asignan entidad autónoma -como objeto de estudio- a una noción "que no fue atendida sistemáticamente ni siquiera por los intelectuales críticos de las zonas centrales: Marx, Kautsky, Lenín, o Lúkacs" (Ortiz, 1989). Desde la periferia, tanto orientales, africanos y latinoamericanos coincidieron desde su origen en la relevancia de la dimensión política en los estudios sobre lo popular.

En líneas generales, los grupos de sujetos a los que refiere estas tesis -habitantes de los territorios de exclusión del primer cordón del Conurbano y sus vecinos de la zona sur de la Ciudad- pueden identificarse a partir de la categoría gramsciana de "clases subalternas": una de las primeras definiciones que rompe con la de "clases inferiores"2, incorpora la

\footnotetext{
${ }^{1}$ Sobre el final del informe de tesis, se retoman los conceptos de de Souza Santos, sobre todo las ideas elaboradas a partir de los cambios en América Latina que le llevan a afirmar que los gobiernos populares latinoamericanos muestran la emergencia del Estado como un "novísimo movimiento social".

${ }^{2}$ A pesar del evidente etnocentrismo -o clasecentrismo- y la carga discriminatoria de categorías tales como "clases inferiores" o "infra clase (under class)", éstas siguen vigentes en el vocabulario de políticos, periodistas y hasta cientistas sociales, para referirse a grupos marginales urbanos. A partir del análisis de los ghettos negros en las ciudades de EEUU, Wacquant afirma que "hay que barrer con el discurso de la infra clase que llenó el escenario del debate renaciente sobre la raza y la pobreza en
} 
noción de proceso social y que, por su riqueza y amplitud, recuperan y legitiman las corrientes citadas.

El debate más fuerte que atraviesa la producción teórica de estas corrientes, en torno a lo popular y lo subalterno en la cultura, está dado por la posibilidad que tendrían o no los subalternos para intervenir en la cultura y para hacerse escuchar. En ese sentido, en 1988 Spivak pública ¿Pueden los subalternos hablar? que plantea una respuesta crítica a la posibilidad de agencia por parte de estos sectores. Para Spivak, la condición de subalternidad viene acompañada de un silenciamiento, de una carencia de voz; para él la violencia epistémica de la dominación colonial borra cualquier posibilidad de acción transformadora. Este debate, -la posibilidad de agencia o no- sigue vigente, sobre él, Michel de Certeu llega a preguntarse si "la cultura popular existe independientemente del gesto que la suprime" (de Certeau, 1970).

Estos recorridos, diferencias y superposiciones conceptuales también están presentes en el campo de los estudios de comunicación y su literatura sobre las prácticas de cultura popular de los grupos subalternos. A partir de la redefinición plateada por el giro semiótico 3

la ciudad (Fainstein, 1993) y reconstruir, en cambio, las relaciones conexas entre la trasformación de la vida cotidiana y las relaciones sociales dentro del núcleo urbano" (Wacquant, 2001).

${ }^{3}$ A mediados de la década del 60, como consecuencia de la crisis de la Ciencia positiva y en el marco de las duras críticas al concepto de racionalidad moderna, se plantea desde las ciencias sociales un nuevo modo de entender la sociedad a partir de su carácter simbólico. Así, con el giro lingüístico o giro semiótico se asume que los seres humanos no podemos dejar de conferir sentidos. A partir de ello cambian los modos de concebir y analizar la escritura y la lectura. En términos comunicacionales cambian las claves por medio de las que se estudian los textos y mensajes en las instancias de producción y recepción; deja de pensarse a la primera 
aparecen, en las ciencias sociales, propuestas superadoras para estudiar la cultura popular, como la distinción que hace el mismo de Certeau (1970) entre estrategias y tácticas de la cultura: las tácticas no tienen lugar -son formas de hacer- y las producciones y consumos cotidianos de las clases populares son pensadas como tácticas de producción de la cultura popular. De este modo, al transformarse el sentido de las prácticas de la cultura popular, podemos pensar, por ejemplo, que leer o mirar TV son también prácticas constitutivas de lo popular en la cultura.

Desde esta propuesta también se vislumbra una solución a la consabida discusión entre cultura popular y cultura de masas, ya que las nociones de apropiación y resignificación que desarrollan autores como Hoggart (1970), Bourdieu (1984), o Barbero (1983), entre otros -para quienes la interpretación es la asignación de nuevo sentido en la instancia de recepciónpermiten identificar sentidos de resistencia y de producción de la cultura popular en el contexto de los consumos culturales masivos.

En América Latina, la apropiación de esta línea teórica tuvo amplias derivaciones y hacia finales de los 70, surgieron las Teorías de la Recepción que indagaron una multiplicidad de

instancia como productiva y a la segunda como reproductiva, y ambas son entendidas como determinadas y determinantes del orden simbólico social. Esto trae aparejado un giro ontológico que trasforma los procedimientos de las ciencias sociales: la actividad de interpretar pasa a ser entendida como constitutiva de todo sujeto y a la vez constituyente del mundo social. De ahí el denominado giro hermenéutico, en el que los científicos sociales reconocen el carácter performativo de la teoría: la comprensión de un fenómeno -y especialmente su interpretación y la escritura interpretativa- son, por un lado, un acto productivo, de creatividad, y, por otro, reproductivo e histórico. Para ampliar estas nociones pueden consultarse Barthes (1994), Geertz (1989), Guiddens (1993) y Schuster (2002). 
fenómenos (entre ellos los urbanos), entre la cultura popular y la masiva. Ellas emergieron de un conjunto heterogéneo de estudios que, bajo el espíritu de época y el influjo de la teoría crítica de la comunicación, trataron de dar cuenta del efecto de modelación cultural que se produjo en nuestras sociedades a partir del desarrollo de la tecnología y las industrias culturales. Desde la clave de la invasión cultural, se estudiaron las transformaciones nacionales, regionales y comunitarias a partir de productos e influencias de la industria cultural foránea. Así los usos, lecturas y apropiaciones diferenciadas de medios y mensajes por parte de distintos receptores terminaron por convertirse en objeto privilegiado de la línea culturalista latinoamericana.

Los autores del culturalismo latinoamericano constituyen una masa crítica que realizó aportes innumerables: por señalar sólo algunas de las nociones más relevantes podemos citar a las vertientes dentro de las que actualmente se forman grandes áreas temáticas, como la educación para la recepción de Guillermo Orozco Gómez (1991) y Valerio Fuenzalida (2000), los consumos culturales de Néstor García Canclini (1984), los frentes culturales de Jorge González (1994), los usos sociales de los medios de María Cristina Mata (2000) y el estudio de las mediaciones de Martín Barbero (1987).

Sobre la conveniencia de indagar los consumos culturales frente al estudio de la cultura popular, el intelectual argentino-mexicano Néstor García Canclini (faro de la producción regional en estudios de comunicación y cultura a partir de la década del 90) afirmaba que hay que mirar cuál es el destino de la modernidad en América Latina desde quienes la producen y 
también desde los receptores y que hay dos caminos para averiguarlo: uno es el consumo cultural, el otro es el estudio y el debate sobre la situación de las culturas populares. "Esta segunda vía en parte se superpone con la anterior, aunque no enteramente: porque los únicos receptores de la cultura no son las clases populares y porque desde el punto de vista teórico y metodológico ambas estrategias de investigación han seguido rumbos separados" (Canclini, 1992).

Pero en el contexto de la globalización fragmentada y las sentencias de muerte a los grandes relatos y las ideologías, el pasaje de los medios a las mediaciones y del pueblo y la ciudadanía a los públicos y consumidores fue opacando la dimensión política y la pregunta por las relaciones de poder. Así, la idea de un receptor súper-activo, capaz de asignar nuevo sentido a toda la producción cultural se volvió una meseta epistemológica que funciona como la contracara de la tesis de Spivak sobre la incapacidad total de agencia por parte de los subalternos.

En torno a estos debates, en la construcción teórica de este trabajo y al referirnos a las particularidades culturales y las identidades de los grupos subalternos que habitan los territorios estudiados, se retoma la posición que desarrolla el argentino Alejandro Solomianski (2004)-que él mismo define entre los estudios culturales y los poscoloniales-. En la investigación Identidades secretas: la negritud argentina, que recupera la constitución histórica de la identidad afrodescendiente en Argentina; el autor ubica a los afrodescendientes en un marco más amplio de grupos subalternos, y para ellos crea el término 
subalternizados: grupos a los que el poder hegemónico les impidió formar parte de la historia oficial. Así, la identidad no está dada por un esencialismo racista -o incluso de clase- sino por una serie de experiencias culturales y socioeconómicas afines: el sufrimiento común de determinado grupo de sujetos que se fueron constituyendo históricamente en lucha con los sentidos dominantes. Solomianski propone revisar, debido a sus implicancias políticas, las representaciones académicas en torno a lo subalterno, para entenderlo como subalternizado: aquello que existe con identidades, sentidos y prácticas culturales propias y posibles de ser estudiadas en sí mismas.

Desde esta perspectiva, las voces populares subalternizadas pueden ser estudiadas por sí y no sólo a partir de lo que las voces hegemónicas dicen de ellas. Así, se retoman estas nociones en el marco teórico, que se relacionan con la distinción que hace Carlo Ginzburg entre "cultura producida por las clases populares" y "cultura impuesta a las masas populares" (Ginzburg, 1976), porque permiten resituar la discusión de problemáticas como el hábitat popular y la pobreza urbana, no para analizar la cultura desde la clave de los consumos de los receptores sino desde el pueblo como actor político. 
Lo urbano, por su parte, se volvió objeto de estudio de las ciencias sociales a finales del siglo XIX en la ciudad victoriana, más tempranamente que lo popular. El especialista en urbanismo, Peter Hall, señala que las pésimas condiciones de los barrios obreros de las ciudades británicas impulsaron a las atemorizadas clases burguesas a hacer algo para solucionar el problema de la vivienda obrera. Es decir, que el urbanismo surge originariamente como política social.

La ciudad gigante se había convertido en un problema en sí misma, en ella vivían algunos ricos y sectores medios rodeados de millares de pobres. Antes, nunca los pobres habían sido tan conscientes de su pobreza, que en el bucólico campo se difuminaba, ni los ricos habían sido tan conscientes del riesgo que corrían sus riquezas o de las pésimas condiciones en que vivían sus congéneres. Así surge la idea de diseñar la ciudad como medio con capacidad de condicionar al individuo.

No obstante, según Hall: "la planificación urbana dependió, sólo de la alianza de los propietarios del suelo con el votante de clase media dueño de una casa, que no tenía ningún tipo de interés en los programas de viviendas para pobres" (Hall, 1996). En estos primeros años aparecieron las imaginativas propuestas de los anarquistas británicos encabezados por Howard, e ideas de reforma social que con los años se quedaron en nada. Pero a pesar de estas ideas confiadas en el género humano, el urbanismo se consolidará como el substituto elegido por los poderosos para no aplicar políticas sociales más directas. 
En este período inicial de estudios sobre la ciudad, la línea más destacada fue la escuela sociológica alemana y "lo urbano" comenzó siendo analizado por oposición a "lo rural". Trabajos en ese marco como los de Töennies (1887) y Simmel (1903) fueron retomados por gran cantidad de intelectuales, incluso Gino Germani (1976) en Buenos Aires.

Entre 1920 y 1930 se empieza a estudiar la ciudad en la Escuela de Chicago -corriente a laque nos referimos en el capítulo anterior- (Anderson, 1923; Park, 1928; Wirth, 1938). Esas investigaciones constituyeron la base de la sociología urbana norteamericana y también de la -hoy denominada- antropología urbana (Redfiel, 1930; Lewis, 1953; Lomnitz, 1975) .

Los estudios y las líneas teóricas fueron avanzando por contraposición de perspectivas y así, en los años 70 la crítica al funcionalismo viabilizó el surgimiento de estudios que "se centraban en aspectos más estructurales, para usar los términos de la época (Castells, 1972; Topalov, 1979; Harvey, 1979)" (Chávez, 2001). A la vez, el giro epistemológico que mencionamos más arriba atravesó todos los campos de las ciencias sociales y propició la emergencia de nuevas perspectivas de estudio para contar la historia desde abajo ${ }^{4}$ y la ciudad desde las experiencias y trayectorias de los sujetos, de sus prácticas y sentidos cotidianos, de sus modos de asociarse y estar juntos.

Luego, sobre la ciudad compleja en el marco de la Globalización, podemos señalar los aportes de Bauman (1999, 2006) y Sassen (1999), que retomaremos para referirnos a las

\footnotetext{
${ }^{4}$ El concepto de "historia desde abajo" fueacuñado por Lefevre y popularizado en los 60 por el grupo de historiadores del Partido Comunista de Gran Bretaña: Eric
} Hobsbawm, Raphael Samuel, R. Hilton y E.P. Thompson. 
transformaciones sufridas por el AMBA en la década del 90 y, por último, sobre el modo en que hábitat urbano se relaciona con el habitus popular, son fundamentales los desarrollos de Pierre Boudieu (1993) sobre los "efectos de lugar" y los estudios realizados por Lö̈c Wacquant (2001) en sus indagaciones sobre la nueva pobreza urbana (que se retoman unas líneas abajo) .

En resumen, la problemática de la pobreza urbana y el hábitat popular no surge intempestivamente en ciudades ordenadas, sino que está presente desde el origen de la ciudad moderna (Hall, 1996).

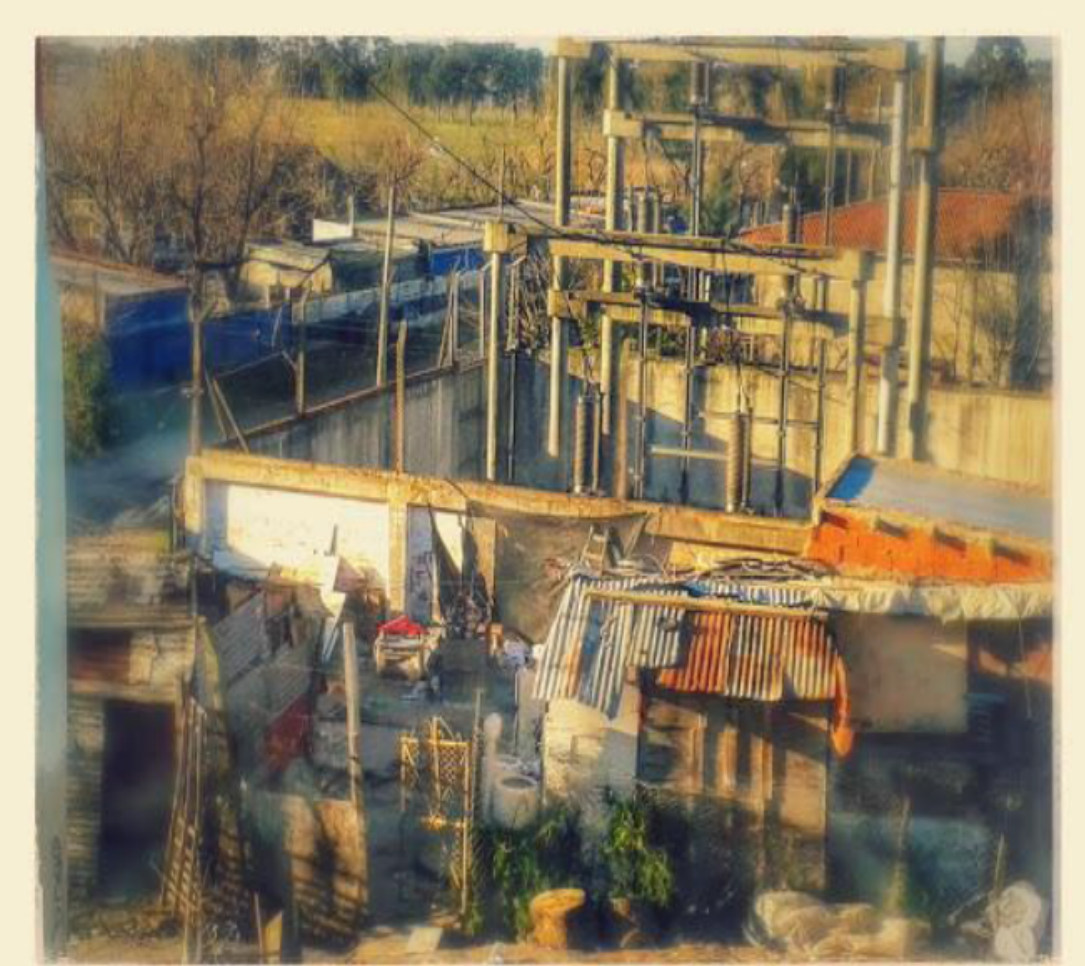


En efecto, las perspectivas sociológicas que analizan los fenómenos sociales producidos en la ciudad global aportan al análisis de las problemáticas del hábitat popular en el AMBA, en tanto que en el nuevo milenio, Buenos Aires se ha vuelto una metrópolis global: aunque tiene características locales, en ella pueden identificarse procesos estructurales propios de la ciudad globalizada también en la puja por el derecho a habitar y transitar el espacio urbano. Los barrios populares, las villas y asentamientos del AMBA son distintos entre sí y con respecto a modalidades habitacionales propias de otras ciudades, pero los desarrollos conceptuales derivados de otros casos como el gueto negro de Chicago y la banlieu parisina, por ejemplo, sirven para iluminar algunos procesos que se desarrollan especialmente en la Ciudad de Buenos Aires y el primer cordón del Conurbano.

Distinto es el caso de los conglomerados habitacionales populares asentados en zonas alejadas de la Capital, más allá del segundo y el tercer Cordón, para los que algunos autores 
acuñaron el concepto de territorios en proceso de "insularización" (Cravino, Fournier, Neufeld y Soldano, 2001 y Fournier y Soldano, 2001). En estos territorios, además de la privación del derecho a la ciudad, asociada a la falta de acceso objetivo, existen características poblacionales más homogéneas: por ejemplo, la totalidad del hábitat es autoproducido a partir de asentamientos relativamente recientes y las prácticas asociativas en torno al empleo y la supervivencia tienden a reproducir las lógicas autogestivas del trabajo rural (Vidarte Asorey, 2011). En cambio, en los barrios ubicados a la vera del Riachuelo, las villas, asentamientos y conventillos conviven con otros modelos habitacionales urbanos, algunos populares y otros no, con los que sostienen una interacción permanente.

En los barrios estudiados, los habitantes de la Isla Maciel transitan varias veces a la semana por el barrio de La Boca, mientras que los de La Boca visitaron la Isla sólo ocasionalmente o no la conocen: "Muy poco porque te queda a contramano ir a la Isla viste... esta como media aislada la isla (risas).", "La verdad es que no conozco mucho a la Isla, la sentí nombrar pero no fui nunca.", "Conozco de pasada nomás porque un día me perdí. Me quería tirar al rio (risas).", "No, Dock Sud sí conozco, pero la Isla Maciel no. Ni quiero ir tampoco.", "Conozco hace mucho, ahora mejoró bastante." Aquí la segregación no depende de la distancia literal, sino de procesos de destitución más cotidianos del orden material y simbólico. Por otra parte, estos territorios no son nuevos, no siempre tienen límites definidos, no están marginalizados de forma homogénea y no necesariamente nacieron como territorios marginales: se trata de un proceso de reconfiguración de la ciudad que Javier 
Auyero explica como "la nueva marginalidad en los viejos territorios" (Auyero en Wacquant, 2001).

El análisis de la marginalización territorial de gran parte del hábitat popular en Buenos Aires tiene algunas coincidencias con el del gueto de Chicago que tienen que ver con su emplazamiento espacio-temporal: la Globalización, en el marco de la ciudad posindustrial del neo-capitalismo avanzado; la metropolización de las ciudades; la aparición de sectores sociales dominantes asociados a la economía transnacional; la transnacionalización de redes de crimen organizado (especialmente vinculadas al narcotráfico y a la trata de personas) y la emergencia de una nueva pobreza urbana segregada territorialmente y excluida del mercado de trabajo.

Sobre algunos puntos de comparación que pueden actuar como disparadores interpretativos, en barrios como Isla Maciel, por ejemplo, ocurrió un proceso similar al que Wacquant describe para el gueto estadounidense: con el período posindustrial y la pérdida de empleo, desaparecieron los sectores medios y las comunidades fueron perdiendo su importancia relativa tanto para las instituciones como para el mercado. Como consecuencia, los habitantes de estos barrios pasan gran parte de sus vidas excluidos del trabajo asalariado y carecen de la posibilidad de proyectar una "carrera ocupacional" (Kessler, 2004) que les permita reinsertarse aún en períodos de aumento de la actividad productiva.

Otro rasgo que permite analogías entre el gueto y los territorios marginalizados estudiados es el concepto del territorio como "Máquina de identidad colectiva" (Wacquant, 
2010). El sociólogo francés señala que, mientras que en espacios como la banlieu, la mayor parte de los vecinos no se reconoce como parte del barrio y afirma vivir allí de modo transitorio, los habitantes del gueto negro construyen su identidad en relación directa con su pertenencia al barrio. En el caso de Isla Maciel ocurre algo similar: la mayor parte de los hogares están habitados por familias que llevan más de una generación en el barrio y hablan de él como parte importante de su identidad. Al ser entrevistados sobre el lugar en el vivirían si pudieran elegir, no sólo los jóvenes -entre quienes es más habitual identificarse fuertemente con su barrio e incluso con su esquina (Saintout, 2002)- también gran parte de los adultos respondieron con frases que hechan luz sobre esta cuestión: "Es un sentimiento el lugar en el que vivo, acá me trajeron mi mamá y mi papá", "¿si pudiera mudarme a cualquier lugar del mundo, dónde me mudaría? A una casa más linda, pero acá". Más que indagar las formas en que el estigma se experimenta, se sufre o se reproduce, la reiteración de respuestas de este tipo nos permite pensar que es posible "desestigmatizar" un territorio, transformando el hábitat y consecuentemente los modos de habitarlo: empoderar a sus vecinos, revalorizando su identidad territorial, en vez de considerarla un aspecto negativo.

Para Wacquant la articulación del concepto de gueto permite "enfatizar el papel del gueto como una incubadora y matriz simbólica para la producción de una identidad estigmatizada en el sentido de Goffman" y permite también "desenmarañar la relación entre guetización, pobreza urbana y segregación" (Wacquant, 2010). Pero el gueto, como "instrumento espacial de segmentación y control etnoracial" tiene a la discriminación étnica como elemento principal, 
en ese aspecto -como ya dijimos- los territorios marginalizados del AMBA tienen otras características. En el caso del gueto negro de Chicago, sus habitantes se diferencian de los vecinos de otros barrios de la ciudad a partir del el color de piel ${ }^{5}$ A partir de la diferencia étnica, se construye una otredad peligrosa en torno al territorio y a los sujetos. Esa discriminación étnica es tan notoria que se naturalizó en la sociedad norteamericana, y hasta investigadores y actores oficiales utilizan categorís como inner city (ciudad deprimida o subterránea) para definir el espacio, y underclass (infraclase) para clasificar a sus habitantes.

Pero más allá de la identificación de los sectores populares con los "cabecitas negras" en Buenos Aires los guetos no se relacionan directamente con la etnia: históricamente la relación etnicidad / territorialidad sigue el modelo de conventillo (que se replicó en las villas de la Capital), en el que convivían personas de distintos países y provincias que tenían en común condiciones socioeconómicas y no las étnicas o culturales (Grimson: $2003{ }^{6}$.

\footnotetext{
${ }^{5}$ En Estados Unidos, los afrodescendientes atesoran una larga historia de discriminación, desde las resistencias locales para abolir la esclavitud (que llegaron a provocar una guerra civil entre 1860 y 1865) hasta la segregación legal que se extendió hasta los '70 -jen el siglo XX!- y que logró interrumpirse sólo a costa de tres décadas de militancia afro en distintos frentes, con gran cantidad de muertos en lucha.

${ }^{6}$ Aunque entre 2001 y 2010 la inmigración (especialmente de países de limítrofes) aumentó en los territorios marginalizados del AMBA, el cambio no es significativo: en 20001 el porcentaje de inmigrantes extranjeros en Argentina era del 4, 2\% y en 2010 del 4,5\%. Estos números son poco relevantes comparados con las tasas de principios del siglo pasado (30\% en 1914 y 15,3\% en 1947, por ejemplo). Además, los porcentajes de inmigrantes provenientes de países limítrofes se mantuvieron estables entre el $2 \%$ y el 3\%, desde la primera medición en 1869 hasta la última realizada en 2010 (INDEC, Censos Nacionales de Población).
} 
La territorialidad en el AMBA siempre estuvo marcada por lo socio-económico y fuertemente vinculada a la posición en el mundo del trabajo.

Así, a diferencia también de otras ciudades de América Latina, el hábitat popular local se acerca más al ejemplo parisino que al de Nueva York, aunque con otras características en relación con la ubicación y extensión espacial, la infraestructura barrial y el tipo de vivienda. Las banlieues, por su parte, son conjuntos de barriadas populares que se ubican en los suburbios de las ciudades francesas. Alrededor de los años 60 comienzan a identificarse estos conglomerados habitados por la clase trabajadora y ya en ese momento las banlieus concentraban inmigrantes extranjeros junto a campesinos franceses que migraban a las ciudades en busca de trabajo.

Las banlieues se asentaron en pueblos o pequeñas ciudades cercanas a la gran ciudad (en los que anteriormente se habían ubicado sectores medios y altos en busca de tranquilidad). Por eso, el paisaje permite la convivencia de viviendas monoparentales tipo chalets junto a conjuntos de edificios que llegan hasta las 20 plantas y 50 departamentos por complejo, al estilo de los monoblocks de Lugano, Ciudad Evita o Dock Sud, cuyos habitantes tenían en común sus condiciones socioeconómicas. A partir de la década del 60 , y con el correr de los años, esos territorios albergaron a migrantes españoles, portugueses y africanos ${ }^{7}$ que convivieron con los sectores populares franceses empobrecidos. Actualmente, la banlieue parisina está

\footnotetext{
${ }^{7} \mathrm{Al}$ principio, los inmigrantes ingresaron al país legalmente para cubrir la falta la mano de obra barata perdida en la Segunda Guerra Mundial y luego fueron ilegales e ilegalizados, con la estabilización económica europea y los cambios en la legislación migratoria.
} 
formada por territorios marginalizados-muchos de ellos señalados como espacios de violencia y depravación- en los que viven excluidos sociales sobre quienes pesa una fuerte estigmatización, la cual aumenta en forma paralela a la cantidad de inmigrantes africanos y europeos del Este (Wacquant, 2001).

A partir de las políticas neoliberales, del estigma social y de la segregación territorial, se desarrollaron rasgos culturales propios de la banlieu: el mestizaje de subalternizados que luchan por la supervivencia en la ciudad. En este caso, como en el de los territorios analizados en esta tesis, la etnia es un elemento importante pero secundario y en términos generales el núcleo de la marginación territorial está dado por la pobreza.

En ese contexto Loïc Wacquant plantea la noción de nueva pobreza urbana o marginación avanzada, que implica una pobreza que suma la marginalización territorial a la destitución económica. Este modelo de exclusión urbana, que se repite en muchas metrópolis del mundo, incorpora la criminalización y la violencia institucional como elementos de control de la pobreza, amparado en la doctrina de la "tolerancia cero" que no propone otra cosa sino la administración de una intolerancia selectiva por parte de un estado policía (Wacquant, 2000, 2010) O estado gendarme o penal (Zaffaroni, 2011). Así, los pobres son forzados a un aislamiento que alterna entre las prisiones y los barrios marginalizados, ambos espacios de destitución en los que la violencia se expresa cotidianamente como única forma de control social. 
Desde la sociología criminológica se conceptualiza este período (el del Estado penal) como el neopunitivismo: se trata de un sistema que reactualiza los métodos punitivos medievales en el contexto del postmodernismo teórico. El neopunitivismo se acuña en Estados Unidos, llega a su punto máximo luego de los atentados del 11 de Septiembre de 2001 al Wall Trade Center y se mundializa a partir del entramado de relaciones de poder que Eugenio Zaffaroni denomina criminología mediática (con relación a la capacidad de los grandes oligopolios internacionales de presionar políticamente a través de los medios masivos de comunicación y de instalar imaginarios estigmatizantes).

Se pueden destacar especialmente dos investigadores críticos del neopunitivismo, David Garland y el ya citado Loïc Wacquant, ambos son europeos pero desarrollan sus investigaciones en universidades norteamericanas. Mientras Wacquant hace foco en las condiciones estructurales y sitúa el núcleo de la criminalización de la nueva pobreza urbana en la exclusión del mercado laboral generada por la Globalización a partir de los años 80; Garland orienta su análisis a las relaciones culturales y afirma que en la sociedad posmoderna reina una suerte de esquizofrenia, que por un lado da lugar a una "criminología de la vida cotidiana", que apela a todos los recursos preventivos mecánicos, electrónicos, etc., pero por otro a una "criminología del otro", que resucita las versiones más tenebrosas del viejo positivismo (Garland, 2001).

Una tercera perspectiva de análisis del sistema punitivo estadounidense (y su mundialización forzada) es la que propone Jhonatham Simon que integra ambas tesis, sostiene 
que la Safe Streets Act de 1968 de Lyndon Johnson marcó un cambio fundamental, caracterizado por el pasaje del modelo del trabajador manual como el ciudadano común del imaginario colectivo, al de la víctima, señalando el comienzo del "gobierno mediante la criminalidad". Para Simon el proceso se aceleró porque desde Ronald Reagan (1981-1989) hasta George Bush (2001-2009) todos los presidentes fueron antes gobernadores de estados -salvo Bush padre, que venía de la CIA, lo que no altera la tesis- que trasladaron al gobierno federal la modalidad vindicativa de la política provinciana, donde los fiscales son elegidos por voto popular y "adquirieron la práctica de fabricar víctimas-héroes como modo de dar el salto a las gobernaciones, sobre la base de campañas vindicativas" (Zaffaroni, 2011) ${ }^{8}$.

Pero Zaffaroni va más allá en la posibilidad de comprender este proceso histórico y postula que el sistema punitivo estadounidense es la forma actual de un sistema de dominación mundial, sucesor del colonialismo (y la esclavitud). En esta tesitura, el criminalista plantea la evidencia de al menos dos modelos sociopolíticos en puja, uno inclusivo y otro excluyente, que se reactualizan de modo tal que uno de ellos -gestionado por el Estado penal y legitimado por la criminología mediática- busca administrar la dominación a partir de regular la exclusión social por medio de la criminalización y la exacerbación de la justicia cautelar- y por otro un modelo opuesto que busca la ampliación de derechos humanos y ciudadanos en pos de la inclusión de los diversos sectores sociales.

\footnotetext{
${ }^{8}$ En Argentina esta modalidad de campaña mediática presidencial apoyada en la lógica vindicativa tiene cobra actualidad en la figura de Sergio Massa y su construcción como precandidato a Presidente en 2015.
} 
Según Zaffaroni, mientras en Europa y Estados Unidos avanza el modelo excluyente: del paso del estado de bienestar a un estado gendarme "que genera violencia y sólo violencia", lo que implica además una preocupante regresión en materia de Derechos Humanos; América Latina avanza a contrapelo hacia un modelo de estado inclusivo (Zaffaroni, 2011 ${ }^{9}$ ). Con esta afirmación, el ministro de la Corte Suprema argentina, se refiere sobre todo al trabajo de los gobiernos progresistas suramericanos en los avances de los juicios por crímenes cometidos durante las dictaduras ${ }^{10}$ así como a las nuevas legislaciones que amplían derechos civiles y ciudadanos (matrimonio igualitario e identidad de género en Argentina, despenalización del consumo de marihuana en Uruguay, ampliación de los derechos de los migrantes en los países de MERCOSUR, por citar algunos casos).

Sin embargo, algo menos en las estructuras jurídicas y bastante más en las fuerzas represivas (policías y militares), esos avances son lentos y complejos en su implementación a la vez que chocan con la vorágine de la mundialización del punitivismo, la parafernalia mediática y política en torno a los discursos sobre inseguridad y la complicidad policial con el crimen organizado -que se apoya cómodamente en los grupos residuales que siguen siendo

${ }^{9}$ Conferencia magistral brindada por Eugenio Zaffaroni en el I Congreso Latinoamericano de Comunicación/Ciencias y Sociales desde América Latina: "Tensiones y Disputas en la Producción de Conocimiento para la Transformación" (Comcis). Facultad de Periodismo y Comunicación Social, UNLP. La Plata, 2011.

${ }^{10}$ Para el año 2012 en Argentina había 875 procesados, 300 personas condenadas por crímenes de lesa humanidad, 12 juicios orales y públicos realizados en distintos lugares del país y 300 causas en trámite en la etapa de instrucción. 
hegemónicos dentro de las fuerzas-. Así en Argentina la legislación, en muchos casos de avanzada en términos de ampliación de derechos y de inclusión social coexiste con altos niveles de violencia institucional e injusticia cotidiana.

El fusible de esa contradicción son los sectores populares, especialmente los pobres. Un caso paradigmático del tipo de violencia al que referimos es el crimen de Luciano Arruga, un joven de 16 años que desapareció de su casa en una villa de Lomas del Mirador, el 31 de enero de 2009. Según la familia y los testigos los problemas de Luciano comenzaron cuando se negó al "reclutamiento": un policía de su barrio le había propuesto trabajar para él delinquiendo. La práctica del reclutamiento es habitual, no sólo en los barrios marginalizados (por la vulnerabilidad de su población), sino especialmente entre los menores, ya que cuando son encarcelados por la propia actividad delictiva es más fácil sacarlos de la cárcel para ponerlos de vuelta rápido a ganar más dinero. Luego de que el joven rechazó la propuesta y bajo el argumentado de que era sospechoso de robar dos celulares, la policía de la seccional $8^{\circ}$ de Lomas del Mirador lo retuvo ilegalmente en un destacamento, allí le hicieron pasar la noche en una cocina, lo golpearon y lo amenazaron de muerte; fue en septiembre de 2011 , meses después desapareció. El caso continúa siendo investigado en la justicia. 
Si bien las grandes ciudades poseen realidades afines en todo el mundo, en Latinoamérica los procesos de metropolización y las experiencias sociales vinculadas a la pobreza urbana tienen, indudablemente, características históricas, culturales y comunicacionales específicas; a las que a su vez les corresponden líneas de investigación y pensamiento propias.

En un repaso sintético, diremos que en América Latina, entre las décadas del '30 y el '50 las ciudades crecen en forma acelerada. Y esa urbanización emerge en paisajes nacionales con escenografías también compartidas: el proceso económico de la industrialización por sustitución de importaciones (ISI), en el marco social y político de los gobiernos populistas.

En esos años, los sectores populares urbanos estaban integrados mayoritariamente por trabajadores formales del sector productivo. En ese contexto, y sobre todo a partir de los '60 y los '70, la tendencia general de la acción colectiva se basaba en la demanda de mejores condiciones laborales y la posibilidad de acceso a servicios urbanos básicos: transporte, infraestructura, agua potable, etc. (Portes, Roberts y Grimson, 2005).

Desde el comienzo de la urbanización masiva en América Latina, la acción de los movimientos sociales fue clave. En líneas generales, en la ISI se destacó el rol del movimiento obrero; en la restauración democrática se fortalecieron los partidos políticos y, a partir de los '90, con la crisis neocapitalista -derivada en crisis institucional- los 
movimientos sociales urbanos latinoamericanos fueron reconfigurándose básicamente a partir de vínculos territoriales y, en menor medida, étnicos y/o de clase.

El interlocutor de las demandas del movimiento obrero había sido, sin duda, un Estado de Bienestar y, a pesar de los cambios en las demandas, la lucha durante los '70 y los '80 siguió orientada a negociar con el Estado: en él, las clases populares veían no a un enemigo -que seguía siendo la oligarquía nacional- sino a un actor clave para asegurar sus posibilidades de acceso y movilidad social.

Pero los cruentos procesos dictatoriales que sobrevinieron, como antesala de los planes de ajuste -afines al Consenso de Washington- que se aplicarían durante los '80 y los '90, tuvieron marcados efectos en las sociedades: la desregulación económica y la privatización de recursos esenciales del Estado -servicios públicos, energía, comunicaciones- atravesaron a lo político, lo cultural y lo demográfico. Desde mediados de los'90 aparecen nuevos modos de acción social, en principio desvinculados del Estado y muchas veces en oposición a él. De todas maneras, en el transcurso de los años de crisis estos modos de acción se fueron institucionalizando y estableciendo relaciones cada vez menos antagónicas. (Roberts y Portes en Portes, A., Roberts, B. y A. Grimson; 2005).

Los Estados de la ISI, anteriores a las dictaduras de los '70 y'80, se caracterizaban por una fuerte centralización, la cual propició grandes movimientos sociales formales (como sindicatos y partidos políticos) capaces de interpelarlos. Pero el libre mercado y la globalización, que llevaron a la descentralización de los Estados Latinoamericanos, colocaron 
en los gobiernos a los sicarios y ejecutores sistemáticos de las políticas de "ajuste". Así, se incrementaron la informalidad de los movimientos, junto a la cantidad y el espectro de las demandas.

En el nuevo escenario, los sectores populares debieron dialogar o confrontar con interlocutores distintos (barriales, municipales y provinciales). Si bien desde lo cultural la descentralización estatal aparentaba recuperar la fuerza de las identidades comunitarias y la participación de la sociedad civil, en el contexto del neoliberalismo funcionó como un factor de fragmentación política y económica: obturó trágicamente la rearticulación del tejido social y trajo nuevos escollos a la capacidad y a la efectividad de la organización popular.

El aumento cuantitativo de los pobres en las ciudades, sumado a la desocupación, generó un cambio cualitativo en la configuración de los sectores populares urbanos: la clase obrera formal se volvió una minoría privilegiada y los movimientos sociales vieron que sus reivindicaciones, y su capacidad de acción, estaban cada vez más vinculadas al ámbito territorial. Así, en las ciudades se solidificaron las organizaciones comunitarias, vecinales, étnicas y religiosas. Estos cambios ocurrieron en diverso grado en los países latinoamericanos y también impactaron de modo distinto en las metrópolis según las sucesivas orientaciones de las políticas urbanas. 
Desde los estudios de comunicación y sus articulaciones con los estudios de cultura en el campo latinoamericano -desarrollado en las primeras páginas de este capítulo-, hay un tiempo bisagra, en el campo de la comunicación social, en el que se empiezan a indagar nuevos fenómenos sociales más allá de los tradicionales estudios sobre medios masivos de comunicación. La ciudad se volvió objeto de los estudios de comunicación en nuestra región, en los años 80, con la ruptura del mediacentrismo "como parte de ese corrimiento del objeto de estudio que se sintetizó en el pasaje de los medios a las mediaciones, según la consagrada expresión utilizada por Martín Barbero (1987)-aunque podrían citarse obras de otros investigadores, como el Proyecto de comunicación / cultura de Héctor Schmucler o la Propuesta de una genealogía de la comunicación de Mattelart-" (Badenes, 2007). Los estudios en comunicación, entonces, cambian el foco hacia los procesos culturales -la producción, circulación, uso y reproducción del sentido- y las prácticas sociales de los sujetos. En ese marco emergen nuevos temas y objetos: el género, las culturas juveniles, los movimientos sociales y la ciudad como espacio de comunicación.

Ya en los 90, García Canclini aseguraba, en relación con la definición teórica de lo urbano y la organización en la ciudad, que a partir del proceso de metropolización de muchas ciudades (entre ellas Buenos Aires) la pregunta de las ciencias sociales por la autogestión 
urbana tomaba un nuevo cariz: entre la fragmentación y la multiculturalidad, por un lado, y la ciudad global, por el otro (García Canclini, 1997) .

Como se dijo, antes de los 80 había tres líneas teóricas básicas para entender la ciudad: aquella que piensa lo urbano en su distinción de lo rural y a la ciudad como núcleo de la modernidad -cuyo principal referente local fue Gino Germani-. Un segundo tipo de definiciones, de la escuela de Chicago, que pone el eje en cuestiones geográfico-espaciales. Y una tercera línea que hace un análisis específicamente económico de las ciudades, viéndolas como derivaciones del desarrollo industrial. Pero a partir de la década del ochenta, el desarrollo del urbanismo posmoderno en Nueva York, y en otras grandes urbes, hizo emerger nuevas claves: ellas permiten ver en las ciudades la fragmentación y la multiculturalidad, para algunos autores (Canclini, 1984, 1990,1997; Castells, 1974, 1981, 2004, Reguillo, 1997, 2000); y, para otros, el modelo de la ciudad global (Bauman, 1999, 2006; Sassen, 1999; Wacquant, 2001) ${ }^{11}$.

Según Ramiro Segura, estas dos grandes líneas de trabajo, la macroestructural y la microsocial, se reproducen a nivel local en los estudios de las ciencias sociales sobre la territorialización de los sectores populares urbanos: "Por un lado, el análisis del emergente mundo comunitario de los pobres urbanos que, como señala Svampa, la sociología argentina contemporánea ha sintetizado como el pasaje de la fábrica al barrio (Svampa, 2005). Por otro

\footnotetext{
${ }^{11}$ En relación con los autores y textos que trabajan las líneas de la ciudad global y la ciudad multicultural, se señalan sólo aquellos que fueron retomados para esta tesis. Lo mismo ocurre con los que se citan unos párrafos abajo como estudios transdisciplinarios sobre ciudad sin que ello implique que no existan otros autores y textos que aborden estas problemáticas.
} 
lado, el análisis de los patrones de segregación residencial de las áreas metropolitanas latinoamericanas, a partir de datos cuantitativos..." (Segura, 2006). Como explica Segura, la limitación de ambos estudios reside en que no dialogan entre sí: mientras la primera línea no contempla los datos estructurales del territorio habitado por los sectores populares urbanos, la segunda (que efectivamente comprueba la territorialización de estos sectores) minimiza la dimensión práctica y simbólica de la vida social.

Pero ambos espacios de indagación ofrecen explicaciones válidas sobre lo urbano. Hoy, así como coexisten enfoques teóricos sobre la ciudad, en el territorio metropolitano también conviven procesos mediados - de manera desigual- por la globalización económica, y prácticas de hibridación, negociación y resignificación cultural propias de la mundialización de la cultura. Paralelamente, en términos epistemológicos, la indagación de los universos microsociales -que había surgido como respuesta a la crisis de la ciencia positiva- no logró por sí sola dar respuestas superadoras a las problemáticas contemporáneas derivadas de las nuevas relaciones de poder, dominación y resistencia.

Sin dudas, las ciudades son escenarios de comunicación. Como señala Pereira, en ellas interactúan los modos de simbolización, la producción y el uso de sentidos sociales y, por lo tanto, son territorios clave para el estudio de las prácticas culturales de comunicación social (Pereira, 1995). Pensar la comunicación / cultura desde la ciudad plantea claves centrales para desentrañar los modos de producir, reproducir y cohabitar la ciudad. Actualmente, a la ciudad se la estudia en forma transdisciplinaria y como espacio de 
múltiples articulaciones epistemológicas. Este carácter de complejidad actúa también en los estudios en comunicación y cultura urbana en América Latina (Jesús Martín Barbero, 1987, 2002; Néstor García Canclini, 1990, 1997; Renato Ortiz, 1996; Armando Silva, 1990, 1992; Rossana Reguillo, 1997, 2000).

Efectivamente, la metropolización de las ciudades está motivando nuevos interrogantes en las investigaciones latinoamericanas. Si dos décadas atrás se reflexionaba acerca de la crisis de la ciudad, en el nuevo milenio estamos frente al renacimiento de las ciudades latinoamericanas y su reconfiguración en metrópolis globales (García Canclini, 1997), lo que nos lleva a construir nuevos objetos más vinculados al derecho a la ciudad y a los modos diferenciales de producción y uso.

Al respecto, creo que una de las nuevas pautas analíticas que nos marca la Globalización es la de la relación característica de la vida urbana, entre lo institucional y lo emergente, desplazó la acción social y cultural, así como la formación de las identidades políticas, de lo macro a lo micro: a la vida cotidiana de los sujetos y sus comunidades. 
En la Argentina, y sobre todo con relación al AMBA, se producen gran cantidad de estudios en materia de pobreza urbana y hábitat popular, especialmente desde la sociología y la antropología urbana. Entre ellos, retomamos los desarrollos de la politóloga Daniela Soldano (2001, 2006, 2008) y la antropóloga María Cristina Cravino (Cravino, 1998, 2006; Cravino, Fernández Wagner, 2010) y las investigaciones del Instituto del Conurbano de la UNGS, al que ambas pertenecen. En la misma línea, se revisaron las indagaciones coordinados por María Carla Rodríguez, María Mercedes Di Virgilio y los equipos de investigación del Instituto Gino Germani y el Movimiento de Ocupantes e inquilinos, MoI (Rodríguez, Di Virgilio y otros, 2007; Herzer, Rodríguez y otros, 2008). Otros aportes significativos (vinculados más directamente con el campo de la comunicación y la cultura popular en el AMBA) son los trabajos de Javier Auyero (Auyero y Grimson, 1997; Auyero, 2001, 2004; Auyero y Swistun, 2008), Alejandro Grimson (Grimson, 2002, 2004, 2005), Pablo Semán (Semán, 2004) y Daniel Miguez (Míguez, 2004; Míguez y Semán, 2006), muchos de ellos escritos en coautoría.

Los aportes de estos textos, que se van especificando a lo largo de la tesis, pueden sintetizarse principalmente en tres aspectos: el primero son los datos estadísticos actualizados, construidos a partir del trabajo de campo, así como la información y análisis del debate legislativo, las políticas públicas, los discursos mediáticos, científicos y sociales en torno al hábitat popular y los barrios marginalizados del AMBA. En este sentido, se recuperó información a nivel regional (Portes, Roberts y Grimson; 2005), nacional y de los estudios de caso realizados en los barrios de La Boca, Barracas y San Telmo, así como también 
en villas, asentamientos, conventillos y casas ocupadas en la ciudad de Buenos Aires y en el Conurbano bonaerense. El segundo aspecto relevante son las nociones cualitativas vinculadas a las caracterizaciones de la cultura popular y las prácticas y sentidos de los sectores populares urbanos que viven en el AMBA. Por último, una parte importante de estos investigadores, reflexionaron sobre la cuestión de la reflexividad en los procesos de construcción de conocimiento y las complejidades que le presenta al investigador el estudio de problemáticas propias de los pobres urbanos. Todos estos aportes se recuperan a lo largo de esta tesis, en mayor o menor medida, en algunos de los aspectos señalados. 


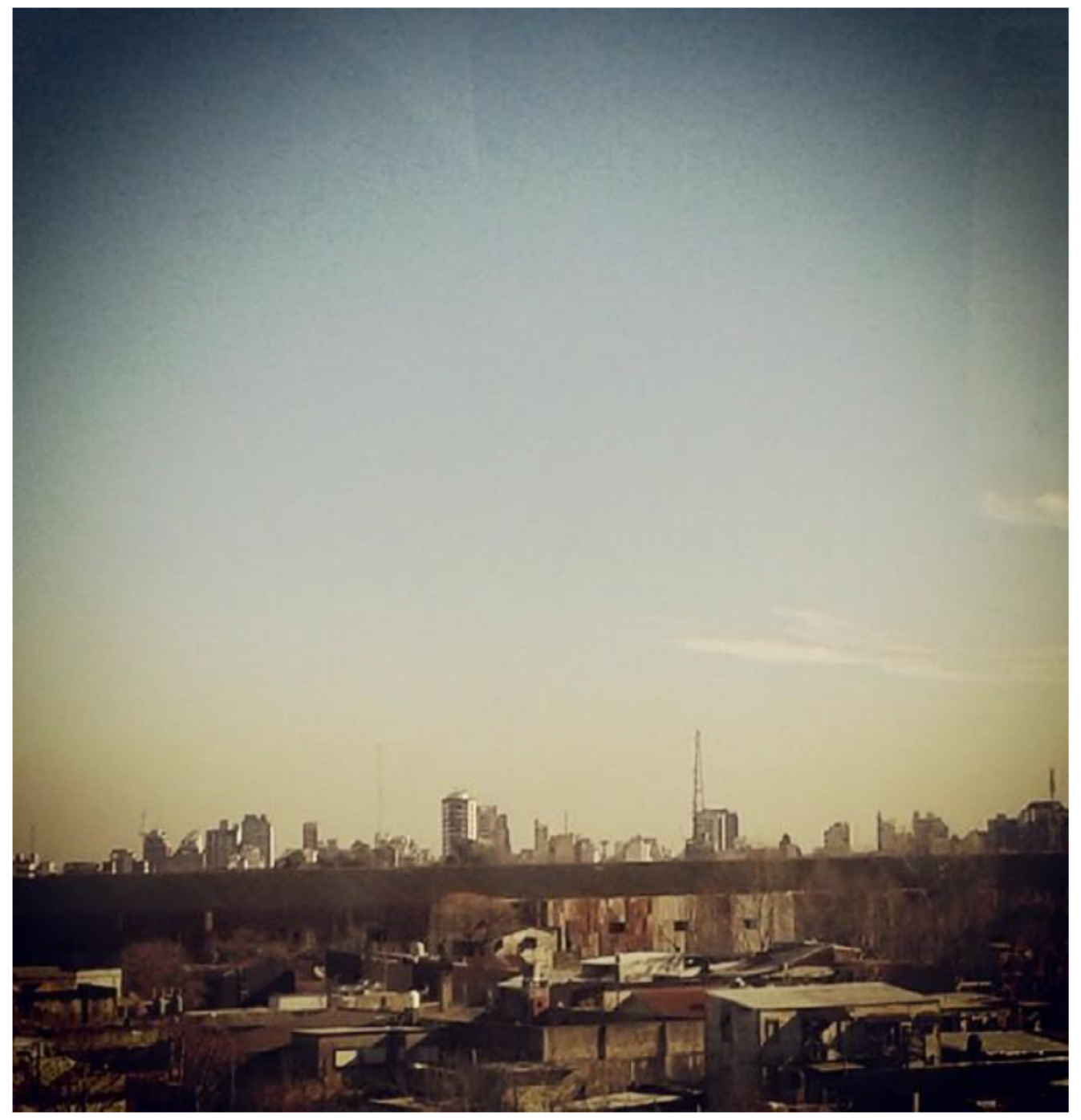

CAPITULO III 
La conformación de las clases populares urbanas, en la zona de las orillas del Riachuelo, estuvo históricamente determinada por problemas habitacionales. El primer gran colectivo inmigratorio, que llegó principalmente desde países europeos entre fines del siglo XIX y principios del XX, encontró sus espacios de trabajo asociados a la economía portuaria, ferroviaria y luego industrial, todas actividades concentradas en la ciudad de Buenos Aires y el Conurbano Bonaerense. En ese marco, se instauró (sobre todo en las inmediaciones del centro histórico) la modalidad habitacional del conventillo, un espacio de hacinamiento desde el que los nuevos habitantes lucharon por su derecho a vivir en la ciudad. Ya antes, en 1880, había en Buenos Aires 1.770 conventillos (www.moi.org). Entre 1860 y 1920, creció vertiginosamente la cantidad de habitantes de inquilinatos mientras que la cantidad de habitaciones disponibles tuvo un crecimiento muy inferior. Sólo entre 1880 y 1892 , la población que vivía en inquilinatos en el AMBA pasó de 51.915 a 120.847 personas, mientras que las habitaciones aumentaron de 24.023 a 31.552 (Revista Polémica, 1970).

Uno de los acontecimientos históricos más significativos vinculados a esta problemática es el que pasó a la historia como la "Huelga de inquilinos" de 1907: un año de aumentos masivos en los alquileres de las piezas y de desalojos violentos a las masas de morosos. El 13 de septiembre, mientras la policía arrancaba a los ocupantes de las 132 precarias piezas de Ituzaingó 279 en la Capital Federal, el barrio de La Boca se convirtió en el germen de la 
medida de fuerza más masiva de la época: cien mil inquilinos se declararon en rebeldía -ante las fuerzas policiales y propietarios o gerenciadores de conventillos- en reclamo de la rebaja del $30 \%$ en los alquileres.

El conventillo constituyó tradicionalmente el espacio en que los migrantes de países diversos (al principio, como dijimos, en su mayoría europeos) compartían su vida cotidiana: el modelo multiétnico y multicultural que configuró el conventillo marcó la relación entre territorialidad y etnicidad del hábitat popular urbano. La convivencia y el intercambio multicultural del modelo habitacional de conventillo constituyeron pautas comunicacionales y organizacionales de los sectores populares urbanos que se trasladaron luego a las villas del AMBA (Grimson, 2003).

Aunque esta modalidad habitacional aún continúa vigente, los conventillos comenzaron a ceder el espacio urbano a las villas. Antes de 1940, las villas no eran un modo de hábitat extendido -en ese año se registraban sólo 5 villas en el AMBA-; los espacios habitacionales populares que más crecieron en la primera mitad del siglo XX fueron los barrios obreros en el Conurbano bonaerense, especialmente en la parte sur del primer cordón.

En las décadas del '30 y '40 la crisis económica comienza a extenderse y el modelo agroexportador pierde su antigua capacidad de absorción de mano de obra. Así, gran parte de la población rural emigra a las ciudades en busca de trabajo.

Específicamente en el AMBA, se registra un aumento sostenido de las villas durante los años '50. En 1958, un estimado censal daba cuenta de que 200.000 personas vivían en 
condiciones de precariedad habitacional en Argentina; en ese año, la población residente en villas y asentamientos precarios en el AMBA oscilaba las 52.500 personas. En 1963, se censaron 42.000 residentes distribuidos en 33 villas; en 1973 la población de las villas de Capital Federal y Gran Buenos Aires ascendía a casi 400.000 habitantes; en 1980, ya superaba los 500.000 (Cravino, 2008).

Además del crecimiento de las villas en la zona metropolitana, durante el peronismo se crearon barrios obreros, en sintonía con las políticas redistributivas que promovían el acceso a la vivienda de los sectores medios y los trabajadores (Torres, 2003). Como las clases populares urbanas estaban conformadas básicamente por obreros y empleados formales, los barrios obreros o proletarios se convirtieron en el hábitat característico de ese período.

Para analizar las direcciones, variaciones e impactos de las políticas sociales sobre los sectores populares urbanos y su hábitat, es necesario comenzar por lo ocurrido en la década que va de 1945 a 1955. Este período resulta un antecedente relevante por varios motivos, especialmente dos: por un lado, porque por primera vez el Estado argentino comienza 
implementar políticas activas para gestionar el hábitat popular y, por otro, porque esa gestión habitacional parte de un déficit ocasionado en gran medida por las crisis de crecimiento que el propio Estado generó, a partir de su modelo industrializador.

Una medida fue el epicentro de la política social durante el gobierno de Perón: la nacionalización del Banco Central de La República, que hizo posible movilizar importantes partidas presupuestarias al Banco Hipotecario Nacional para atacar rápidamente el problema de la vivienda. El hábitat social se había vuelto un conflicto gravitante, ya que al histórico déficit habitacional de las clases populares de Buenos Aires se le sumaban las nuevas dificultades que vivían los migrantes rurales en la ciudad, corridos por la crisis del modelo agroexportador. El censo de 1947, que indagó en las falencias casa / habitación, reveló que 100.000 personas necesitaban viviendas "con carácter de urgencia" sólo en Capital Federal, y la suma ascendía a 650.000 en todo el territorio nacional (Russo, 1971). Hasta ese momento, acceder a una cédula hipotecaria era privativo, ya que éstas cotizaban en el mercado financiero internacional como uno de los títulos más estables, y en consecuencia más caros, de la Argentina.

Entre 1947 y 1955, la política social fue fijada por los sucesivos planes quinquenales: la meta definida era "asegurar a todos los habitantes del país la posesión de una vivienda" (Revista Polémica No 86, 1972). Para eso, el Banco Hipotecario rebajó el interés de sus préstamos a 2,8\% y se privó de percibir comisiones: ello generó un aluvión de solicitudes (32.042) que habían sido denegadas durante sesenta años. Tanto las solicitudes como las 
partidas presupuestarias aumentaron aproximadamente un 300\%; a pesar de esa sobredemanda, el Hipotecario siguió atendiendo las solicitudes e incluso se hizo cargo de la Administración Nacional de la Vivienda bajo una cláusula que decía: "La Nación resarcirá al Banco, al cierre de cada ejercicio de las pérdidas que arrojen las operaciones de fomento" (Art. 16 de la Carta Orgánica, 1947).

Durante los primeros años del gobierno peronista, a instancias del Banco Hipotecario se construyó, en la ciudad de Buenos Aires, un grupo de monoblocks agregados al barrio Marcelo T. de Alvear en Alberdi y Lacarra; el barrio Curapaligüe, ubicado en la calle homónima y la Avenida del Trabajo; un racimo de monoblocks paralelos a la General Paz y el barrio Martín Rodríguez en La Boca; también, el barrio San Martín en Merlo, y el Villa Concepción en el partido de San Martín.

Sólo en 1947 se reconstruyó la ciudad de San Juan -destruida luego del terremoto del '44y se construyeron 20.000 unidades en el resto del país. El monto asignado ese año para la política de viviendas, cercano a los 2.400 .000 pesos, llegó a 23 millones en 1948 y a 25 millones en 1949 (Russo, 1971). En términos de política habitacional, en sólo tres años de gobierno, la frase "Perón cumple" se volvió una verdad inobjetable.

En 1952, el Banco Hipotecario llegó a escriturar más de 41.000 operaciones por 3.400.000 metros cuadrados de superficie cubierta (las cifras más altas de toda su historia). Sólo en la Provincia de Buenos Aires se otorgaron 18.000 préstamos para cubrir casi 2 millones de 
metros cuadrados de viviendas. Ese año se cumplieron las metas del Plan Quinquenal: asegurar la tenencia de una vivienda propia a los hogares más desposeídos.

Luego surgió una segunda política habitacional destinada a los sectores obreros y de clase media: el plan Eva Perón, que consistió en créditos a 50 años, a bajas tasas de interés, destinados a la compra de viviendas unifamiliares. Con trámites simplificados al máximo, la cartera de clientes del Banco Hipotecario creció exponencialmente, lo que permitió cubrir rápidamente los fondos necesarios para las obras planificadas para el período '53-'55, y la inusitada demanda de materiales impulsó fuertemente el crecimiento de muchas industrias (productoras de cemento, cal, bloqueras, sanitarios, etc.).

En el primer año de vida del plan Eva Perón se construyeron en todo el país viviendas por 4.700.000 metros cuadrados, contra todos los esquemas imaginados hasta el momento. Las obras planificadas eran colosales y la mayoría llegaron a concretarse: sucesivamente se inauguraron el barrio Primero de Marzo de 177 viviendas; el Diecisiete de Octubre, con 784 unidades; los monoblocks de General Belgrano, con 131 departamentos; el barrio Los Perales en Mataderos; que tenía nada menos que nueve pabellones con 960 departamentos; un segundo barrio también denominado Diecisiete de Octubre en la Capital Federal; el barrio Presidente Perón de Rosario, con 106 viviendas individuales y 10 monoblocks, y el 45\% de la obra total de Ciudad Evita en las cercanías de Ezeiza, que preveía 10.000 viviendas, oficinas públicas, centros cívico-comerciales, dos estadios de fútbol y una veintena de escuelas y colegios secundarios (Russo, 1971). 
Con el derrocamiento de Perón, por el golpe de Estado del '55, cayeron estrepitosamente los índices de la industria de la construcción y desaparecieron los planes habitacionales. El Banco Hipotecario comenzó a limitar la asignación de créditos y los montos otorgados. El criterio de las nuevas autoridades de la autodenominada "Revolución Libertadora" sobre las prioridades del gasto público fue diametralmente opuesto al del gobierno peronista: ninguno de los proyectos impulsados en el período anterior se continuó.

En Sudamérica, durante los '50, '60 y '70, el espíritu de época estuvo marcado por el desarrollismo y el aumento de la población urbana, el ritmo de crecimiento de ciudades como Buenos Aires y Montevideo se aceleró en forma paulatina. En términos habitacionales fue desordenado pero ello en principio no produjo una segregación espacial notoria, quizás porque había más territorio disponible. De cualquier forma, los sectores populares -aun cuando tuvieran acceso al empleo- no contaban, en la ciudad, con los recursos necesarios para acceder al mercado inmobiliario, a su vez deficiente en relación con la capacidad de generar nuevos loteos e infraestructura acorde. De hecho, muchos especuladores del sector animaban a los trabajadores a comprar tierras en las zonas periféricas, en las que no había 
infraestructura ni servicios, y se accedía a dudosos títulos de propiedad bajo promesa de que allí llegarían grandes autopistas, nuevos sistemas de transporte, etc. (Grimson, 2003$)$.

Durante este período, los sectores populares debieron ingeniárselas para construir sus viviendas como era posible, sin planificación ni dirección estatal: se edificó de manera semilegal e ilegal y se tomaron u ocuparon tierras en su mayoría fiscales. Más allá de este desorden en la urbanización, para principios de los años '70 Buenos Aires era una de las ciudades más ordenadas de América Latina, aunque ya se insinuaban patrones habitacionales de segregación: los sectores medios y altos se ubicaban en el centro de la ciudad y crecían hacia el norte sobre la margen del Río de la Plata en busca de viviendas espaciosas y modernas; los sectores populares, por su parte, crecían desde el sur de la capital hacia las zonas periféricas del Conurbano.

Se impuso un sentido de ocupación y uso territorial en degradé, en el que la frontera más visible es la que separa la Provincia de la Ciudad, especialmente entre la margen sur que divide la Capital del Conurbano (Cherrutti, Grimson; 2005). Esta tendencia habitacional se mantiene aún hoy, en relación con el eje socioeconómico y con el ecológico: mientras las clases medias y altas se asentaron en zonas con mejores locaciones ecológicas, las clases populares fueron ocupando áreas con mayor grado de contaminación.

Hasta los años '70, las villas y barrios obreros no predominaban el paisaje urbano -aunque crecían en el Conurbano- y sus habitantes eran una minoría dentro de los sectores populares 
capitalinos. No obstante, desde el período de la ISI, a través del proceso narrado se fue generando una creciente segmentación socio-espacial.

En la última dictadura militar, con la implementación de sucesivas políticas de erradicación de villas se interrumpió la tendencia al crecimiento y bajó estrepitosamente la población villera de Buenos Aires. Entre el '62 y el '76 la población de las villas capitalinas creció en aproximadamente $13 \mathrm{mil}$ personas al año. A partir de 1976 , y durante los años de la dictadura, la tendencia se invirtió a razón de 45 mil personas por año. Con el comienzo de la etapa democrática, y el consecuente abandono de las prácticas de asesinato y persecución, la tendencia al alza se retomó con un crecimiento anual aproximado de 1.000 personas (ARI, Legislatura de la Ciudad de Buenos Aires, 2003).

Lo ocurrido a partir de los distintos programas de erradicación de villas -pergeñados y dirigidos casi en su totalidad por el brigadier Cacciatore ${ }^{12}$, Intendente de facto de la

\footnotetext{
${ }^{12}$ En ocasión del Ballotage del 24 de junio de 2007 en la elección a Jefe de Gobierno de la CABA, el candidato Mauricio Macri, actual alcalde de la ciudad, señaló en una entrevista con el Diario Clarín que rescataba las políticas del Brigadier Cacciatore con relación las villas(Clarín, domingo 17 de Junio de 200$)$. La política de Macri fue la creaciónpor decreto el 29 de octubrede 2008 de la Unidad de Control del Espacio Público porteña (UCEP) que fue denunciada reiteradamente, entre otras
} 
Ciudad, y en el último tramo por Del Chioppo ${ }^{13}$, su reemplazante- repercutió en los territorios del Gran Buenos Aires. La expulsión masiva de los sectores pobres de la ciudad generó un aumento notable en la cantidad de asentamientos en el Conurbano. No existen, sin embargo, datos oficiales que permitan determinar con exactitud en qué medida repercutió este desplazamiento en el mapa habitacional.

De esto da cuenta el memorable informe "La verdad sobre la erradicación de villas de emergencia en el ámbito de la Capital Federal" escrito y publicado, durante la última dictadura, por los siete curas villeros": "Nosotros, un pequeño grupo de sacerdotes, sin apoyo, ni medios, no hemos podido montar una oficina con personal y recursos para elaborar cifras y estadísticas. Pero hace más de diez años que trabajamos en estas villas y desde hace ya más de tres, que diariamente hemos tenido que escuchar y compartir las angustias de miles

razones, por actuar como una patota, abusar de la autoridad, privar ilegítimamente de la libertad y provocar agresiones físicas y morales a las personas en situación de calle (Página/12, 12/04/2009). En 2009 la UCEP fue desmantelada en medio de un escándalo, pero unos meses más tarde comenzó un trabajo similar Servicio de Higiene Urbana (dependiente del Ministerio de Ambiente y Espacio Público de la Ciudad). Estas prácticas violentas siguen vigentes: en febrero de 2013 el servicio de higiene urbana junto a grupos de efectivos de la nueva Policía Metropolitana, entre ellos algunos "de civil" (que actúa sólo en algunos barrios de la CABA y debería ser sólo una fuerza preventiva de calle) reprimieron fuertemente a golpes y balas de goma a vecinos que se oponían al enrejado del Parque Centenario y a periodistas que cubrían el hecho.

${ }^{13}$ A pesar de su rol en la erradicación de villas durante la última dictadura militar, con la llegada de la democracia Del Chioppo se convirtió en Profesor de la materia "Derecho Constitucional" en el Colegio Nacional de Buenos Aires, dependiente de la Universidad Nacional de Buenos Aires. El dato me consta, ya que fui su alumna en 1995.

${ }^{14}$ Hector Botán, Miguel Ángel Valle -Villa Lugano-; Daniel de la Sierra -Barracas-; Rodolfo Ricciardelli, Jorge Vernazza -Bajo Flores-; José Meisegeier -Retiro- y Pedro Lephaille -Mataderos-. 
de erradicados; hemos visto con nuestros propios ojos las angustias de centenares de familias realojadas de una villa a otra en condiciones cada vez más miserables; hemos visitado lugares del Gran Buenos Aires donde se levantaron nuevas y pobres villas con erradicados de la Capital Federal (...) Por lo tanto, todas estas familias expulsadas de las villas de la Capital Federal han sido trasladadas con su ilegalidad y su miseria a los municipios del Gran Buenos Aires. Con el agravante de que la infraestructura, los servicios y los recursos de estos municipios para asimilar estos nuevos contingentes de población son muy inferiores a los de la ciudad de Buenos Aires, la que, por otra parte, recibe casi la totalidad del aporte laboral de todos ellos" (citado en Blaustein, 2001).

Es decir, disminuyó la población en las villas de la Capital pero aumentó en el Gran Buenos Aires. Aunque no podamos dar cifras totales acerca de la variación real entre los habitantes de villas y asentamientos en el área metropolitana en su conjunto, sabemos que a partir de la vuelta de la democracia la población villera en Capital creció a un ritmo anual de 1.000 personas; muchas de ellas, es de suponer, provenientes del Conurbano. Por supuesto, los nuevos asentamientos bonaerenses no quedaron abandonados: comenzaron o continuaron sus propias historias territoriales de marginación.

Eduardo Blaustein señala que los Partidos que absorbieron la mayor cantidad de población villera fueron La Matanza, con un 21\% de los erradicados, Lomas de Zamora, con el 6,9\% y Merlo, con el 8\%; a ellos les siguen Moreno, Quilmes, General Sarmiento y Florencio Varela. Según el autor, a partir de 1981, en el Gran Buenos Aires comienza a producirse "un nuevo 
fenómeno social: el de la formación de asentamientos" (Blaustein, 2001). Este fenómeno no se debe únicamente a la relocalización forzada de la población villera de Capital Federal: con la imposición del modelo neoliberal en la dictadura, muchos de los barrios obreros periféricos se empobrecieron y se ampliaron de forma irregular a partir de la ocupación de tierras. Así, se convirtieron en grandes territorios marginales con características propias. Existen varios casos paradigmáticos: la Isla Maciel en Avellaneda, cuya población, hasta finales de los '70, se componía de trabajadores industriales, astilleros y portuarios, además de las tradicionales trabajadoras sexuales; o el barrio Don Orione, en Claypole, que fue un barrio obrero hasta los años '80 y se reconfiguró hacia fines del siglo pasado, como uno de los asentamientos más extensos del Conurbano sur.

Con el retorno democrático, la agenda estatal retomó el tema de las villas y asentamientos urbanos y se crearon distintos programas -ahora denominados de "radicación"- que, con intención de generar políticas participativas, buscaron un interlocutor barrial. Pero según afirma María Cristina Cravino, "no se partió de un conocimiento de la realidad (relevamientos 
o investigaciones) o de la concertación, sino que desde el Estado se quiso construir un intermediario a la medida, así sucedió con el movimiento villero" (Cravino, 1998).

El programa se fue desgastando: un informe del Centro de Estudios Legales y Sociales, CELS, del año 1997 denuncia que el Programa de Radicación de Villas dejó de tener presupuesto en 1994 y, al momento de la elaboración del informe, el único caso en el que seguía actuando era en la villa 31 -por la importancia urbanística y estratégico-inmobiliaria de estos terrenos fiscales del barrio de Retiro- ${ }^{15}$. El ejemplo es una muestra de lo que ocurrió en muchos territorios en relación con la intervención estatal y los modos de implementación de las políticas sociales: la voluntad manifiesta de generar políticas participativas se vuelve un bluff cuando una sola de las partes (el Estado) determina la posición de la otra, así como los encargados de plantearla. Si el diagnóstico no busca revelar la voz invisibilizada de los sectores populares, potenciarla y dotarla del capital simbólico necesario frente a las voces hegemónicas, la participación ciudadana es una falacia. Este aspecto también es central en las políticas habitacionales y especialmente en los procesos de urbanización.

Durante la década del '80, un factor fue determinante en la disminución del acceso al hábitat de los sectores populares en el AMBA fue la desaparición del mercado de lotes a mensualidades a causa de los reiterados procesos de inflación e hiperinflación. La financiación a largo plazo para el hábitat popular había sido una práctica habitual desde principios del siglo XX (reorganizada y ampliada durante los gobiernos de Perón), y su

\footnotetext{
${ }^{15}$ En julio de 2013, el precio de los terrenos en la Villa 31 alcanzaba los 1.000 dólares el metro cuadrado, bastante más que en muchos barrios del Conurbano Bonaerense.
} 
desaparición arrastró a la ilegalidad habitacional a muchas familias. Este es otro de los elementos centrales en el quiebre de las posibilidades de ascenso social y del aumento de la pobreza estructural por sobre la transicional.

En consecuencia, el aspecto característico de este período, en relación con la estructura habitacional del AMBA, será la aparición de una nueva forma de hábitat y producción de los sectores populares: el asentamiento. Esta modalidad se inició en 1981, con la toma ilegal de terrenos en la zona sur del Conurbano Bonaerense, y, para finales de la década del 90, ya había un centenar (Merklen, 1997).

Las ocupaciones ilegales de tierras, altamente masivas, estuvieron protagonizadas por vecinos expulsados de la ciudad y de otros barrios del Conurbano, no por migrantes extranjeros o de otras provincias. En decir: el fenómeno de los asentamientos como nueva forma de producción de hábitat no respondió a un aumento objetivo de la población metropolitana, sino a una reconfiguración forzada del hábitat popular.

En términos organizacionales y culturales, los asentamientos se caracterizaron por planificar el uso y desarrollo del futuro barrio, antes de ocuparlo. Esto se vincula con la relación que los ocupantes pretendieron establecer con el resto de la Metrópoli. Por medio de la organización, la planificación y la gestión del territorio, los asentamientos intentaron asimilarse a otros barrios obreros del Conurbano, imitando su configuración -calles, loteo, manzanas y plano en damero-. El plan era asentarse y normalizarse para constituirse en un barrio más y, a la vez, diferenciarse de las villas. 
Como desarrolla Denis Merklen, el asentamiento como modelo habitacional fue la respuesta a una identidad amenazada: los ocupantes no querían ser vistos como villeros, esa categoría social tan estigmatizada. Entre las familias empobrecidas tiende a operar el temor a ser relegadas al ecosistema de la villa: más allá de la precariedad de las viviendas, actúan aquellas representaciones urbanas que conciben a la villa como un territorio de promiscuidad y violencia (Merklen, 1997): un lugar hostil para habitar. El mecanismo de defensa identitaria está fuertemente ligado a la dificultad de estos sectores para reconocerse, no ya como pobres, sino como excluidos.

Desde el punto de vista del rol del Estado, los años '80 marcaron el inicio de los programas sociales a gran escala desde el gobierno nacional. Las crisis inflacionarias potenciaron la necesidad de implementar programas alimentarios: el Plan Alimentario Nacional (PAN), el más importante de la época, se llevó a cabo en 1983, durante el gobierno radical de Raúl Alfonsín. Pero la crisis inflacionaria de 1989, el estallido de la hiperinflación y las denuncias de irregularidades en su aplicación, determinaron su fin.

La redefinición del rol del Estado en los '80 y' 90 trajo consigo la consolidación de la concepción "moderna" -que hoy caracterizamos como neoliberal- de las políticas sociales: asistencialistas, compensatorias y focalizadas. Esta etapa, desde la recuperación democrática hasta la crisis de 2001, se caracterizó por la reducción presupuestaria del dinero destinado a la inversión pública. 
Después de la destitución de Juan Domingo Perón por parte del golpe militar de 1955, la preocupación estatal por la vivienda fue retomada recién en 1972, pocos años antes del comienzo del período económico aperturista '76-'02 (Torrado, 2004). Ese año se creó un fondo continuo para el financiamiento de la construcción de viviendas: el Fondo Nacional de la vivienda (FONAVI), que apuntó a favorecer a la industria de la construcción -que venía cayendo desde el segundo lustro de la década del '60-por medio de la producción masiva de viviendas. Durante sus primeros veinte años, el FONAVI promovió la construcción de conjuntos habitacionales muy parecidos entre sí -en los que no se tuvo en cuenta la particularidad de cada territorio de emplazamiento-: torres o tiras de edificios de dos o tres pisos con algunos espacios de uso común, para los que en general se eligieron locaciones periféricas con escasa demanda a nivel urbano.

Con las sucesivas crisis inflacionarias de la década del '80, muchos de los proyectos se frenaron y quedaron abandonados. Los que siguieron bajaron los estándares de calidad, se malterminaron los edificios y se suspendieron las construcciones de espacios colectivos (Rodríguez, Di Virgilio y otros, 2007). Sumado a esto, los proyectos de hábitat popular vehiculizados a través del FONAVI no tuvieron en cuenta los aspectos vinculados al uso y 
mantenimiento de los edificios, por lo que para principios de los '90 la mayoría de ellos se encontraban en condiciones de abandono poco apropiadas para la vida.

En la década del 90, la desarticulación del Estado alcanzó también al FONAVI: se recortó drásticamente el presupuesto con la suspensión del pago de salarios, que representaban el 50\% del total, y a partir de 1993 se descentralizó la estructura: los escasos fondos restantes comenzaron a transferirse directamente a las Provincias y el gobierno central perdió la capacidad de dirigir y fiscalizar el funcionamiento del FONAVI. A mediados de la década el Estado retomó la iniciativa, pero para profundizar las reformas neoliberales: en 1995 se sancionó la Ley Federal de Vivienda ( ${ }^{\circ}$ 24.464), que definía parámetros y restricciones para el gasto y establecía como prioridad del FONAVI la activación de circuitos financieros vinculados a la industria de la construcción (Rodulfo, 2003). 


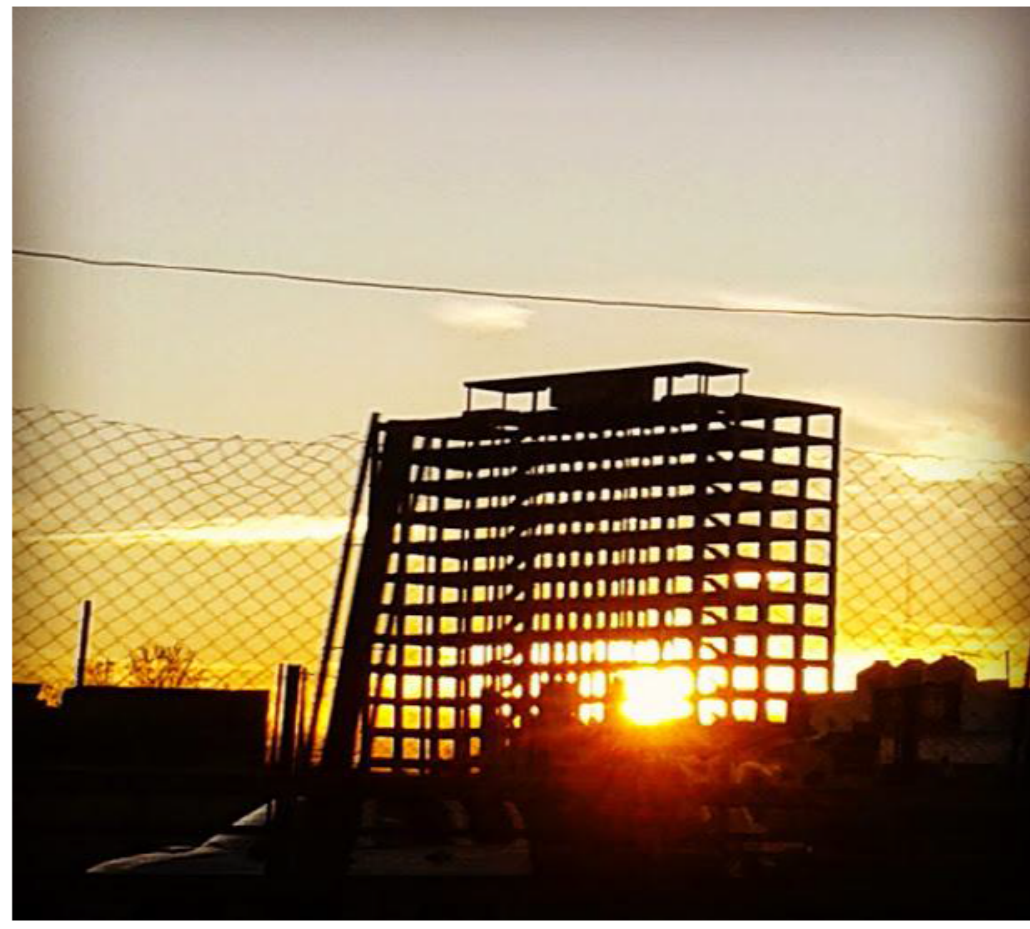

$\star \star \star$

Decíamos que si bien entre las décadas del 80 y 90 se inician distintas acciones públicas orientadas a atender las necesidades de los grupos de menores ingresos, la poca sistematicidad y organización hacen que no puedan considerarse políticas oficiales (Rodríguez, Di Virgilio y otros, 2007). Junto a la falta de programas sociales integrales, 
otras políticas derivaron en la pauperización del hábitat popular urbano: la desregulación del uso y el valor del suelo, la liberalización del monto de los alquileres y la privatización de los servicios urbanos básicos. Las políticas neoliberales implementadas en los ' 90 llevaron a una notable pauperización del hábitat popular: en el Conurbano bonaerense, los hogares en viviendas irrecuperables pasaron del 50,6\%, en 1991, al 61,4\% en 2001. El resto de los indicadores (hogares deficitarios, vivienda precaria recuperable, hogares con hacinamiento a nivel nacional, en el AMBA, y en la Capital Federal) permanecieron con índices similares y en algunos casos mejoraron (EPH, INDEC).

Las características habitacionales del AMBA (el modelo en degradé que opera como tendencia desde la década del 70) y las variaciones demográficas durante los ' 90 plasmaron el proceso de exclusión socioeconómico en lo territorial. En 1991 se estimaba que la población en las villas de la Capital Federal ascendía a casi 51.000 habitantes. Según un documento publicado por la Legislatura de la Ciudad de Buenos Aires, en el decenio 1993-2003, y hasta el neoconservadurismo menemista, la tasa de crecimiento era de aproximadamente 1.000 personas por año. Pero la cifra se cuadruplicó y llegó a más de 4.000 personas por año hacia fines de la década.

No obstante, las variaciones más importantes en el modelo habitacional tuvieron que ver con la transformación de la estructura urbana del AMBA, debido al proceso de privatización de las empresas nacionales y a la inversión extranjera en infraestructura inmobiliaria. Durante los '90, la relación entre espacio y producción estuvo marcada por la tendencia globalizante 
en las metrópolis del mundo. Como plantea Sakí Sassen, los restaurantes caros, casas de lujo y tiendas gourmet se multiplicaron en la ciudad globalizada (Sassen, 1991).

Buenos Aires no fue la excepción: en su área metropolitana se concentraron la mayor parte de las inversiones. De acuerdo a la declinación total de la función industrial, la ciudad se reacondicionó en función de lógicas de consumo de servicios avanzados. Es la nueva ciudad del capitalismo postfordista (Ciccolella, 1999), un territorio de puja por la organización socioespacial que implica una dinámica de exclusión / incorporación de áreas habitables. Una ciudad dual (Sarlo, 1996) en la que los capitales extranjeros que dominaban la economía nacional se unieron a los sectores altos y medios para expandir su ocupación y controlar el espacio urbano, mientras expulsaron hacia otros territorios a los sectores populares, cada vez más pobres.

En principio, los barrios porteños pasaron de la articulación horizontal -que propiciaba la circulación horizontal del territorio- a una densificación vertical en forma de red, que conecta sólo enclaves de interés para el desarrollo del capitalismo global. Así, la inversión inmobiliaria en la ciudad se orientó a edificios de categoría, hoteles de lujo, complejos de oficinas clase A, shoppings, hipermercados, y grandes torres de vivienda para los sectores altos y medios altos (Ciccolella, 1999).

Esta reconfiguración del espacio urbano afectó a la unidad territorial tradicional, la manzana, y desestructuró los patrones de localización comercial. Esto hizo variar las dinámicas de tránsito y uso del espacio y las redes de comunicación establecidas por los 
habitantes. La nueva metrópolis global acentuó irremediablemente la segregación y potenció la invisibilidad de la pobreza. A partir de este esquema, un habitante de clase alta pudo circular por la ciudad a través de esa red diferenciada (de su departamento en torre o casa en country, por autopista, a la torre de oficinas o a los shoppings de barrios ABC1) sin ver siquiera un pobre en el camino. Desde entonces, para los sectores altos la interacción personal con las clases populares se redujo a la mera reproducción del imaginario construido por los medios masivos y, en menor medida, los comentarios oficiales, casi siempre vinculados al discurso de la inseguridad.

En el territorio suburbano, sobre todo en la zona norte, los capitales internacionales y transnacionales se aplicaron al desarrollo de barrios cerrados, privados, countries, grandes centros comerciales, autopistas y accesos que permiten la comunicación rápida con los barrios ricos de la Capital, pueblos privados y hasta ciudades privadas como Nordelta (en el municipio de Tigre). Por supuesto, las modificaciones repercutieron en las condiciones de hábitat y ocupación territorial de las clases populares y, entre ellas, en el sector de los excluidos -que emerge y comienza a crecer dramáticamente durante la década del '90-.

Según un informe socio-habitacional del grupo Atlas Buenos Aires, al ver las variaciones totales del hábitat durante este período se descubre que la segregación siguió un patrón de deterioro central (capital y primer cordón del Conurbano) y cierta mejoría en las condiciones socio-habitacionales de asentamientos preexistentes en el Conurbano Bonaerense: "Mientras puede observarse que el promedio de hacinamiento desciende en los anillos 2, 3, 4 y 5, 
mostrando predominantes signos de mejoría (procesos de regularización dominial y consolidación y mejoramiento de los asentamientos precarios), cuando se pone la atención en el área central se registra un aumento del hacinamiento que se explica por el crecimiento de las villas, la intrusión de edificios desocupados, el deterioro de hogares de sectores medios con aumento del número de miembros sin posibilidades de ampliación de la vivienda, etc." (Abba, Furlong, Susini y Laborda, 2008).

No obstante, el balance acerca de la agenda de reivindicaciones populares durante los 90 muestra que perdió fuerza el reclamo por la propiedad de la tierra: debido el aumento desmedido de la desocupación, creció el reclamo de trabajo genuino (en Portes, Roberts y Grimson, 2005). Hacia fines de los '90 se realizaron algunas obras de infraestructura: asfalto, servicios y, en menor medida, planes de tenencia de tierras. Básicamente, por causa de las políticas focales descentralizadas aplicadas por los Municipios o Partidos Políticos en el Conurbano, o por la auto-organización vecinal en el caso de las villas de Buenos Aires (Auyero en Wacquant, 2001). Entonces, aún en este contexto de inequidad, los problemas de vivienda encontraron cierto margen de solución, sobre todo en comparación con la gravedad de la problemática del empleo.

Antes se mencionaron las crisis de crecimiento que enfrentaron consecuentemente los gobiernos populares de Perón y Kirchner/Fernández de Kirchner, producto de la implementación de modelos industrializadores; la década del 90constituye el caso opuesto y así lo muestra la 
agenda de los sectores populares: el hambre se impuso como una necesidad más urgente que la vivienda, aunque ambas necesidades configuren derechos igualmente justos.

Durante la primera década de gobiernos kirchneristas (2003-2013) hubo un cambio de paradigma en materia de planificación y gestión de políticas sociales, asimilable al ocurrido en los gobiernos de Perón: paulatinamente el Estado nacional fue recuperando la capacidad de conducción de la política social. Este cambio se realizó por medio de múltiples y complejos procesos. Aun cuando la dirección política se mantuvo en todo el período, las condiciones estructurales fueron cambiando en consecuencia y es necesario situar cada medida para comprender su impacto en contexto: la eficacia del PROMEBA es debatible si la analizamos desde 2014 y a la vez sería aventurero imaginar políticas como el plan Conectar Igualdad en la Argentina del 2003. Esta necesidad de poner en situación lo que fue ocurriendo en la interacción entre los sectores populares y el Estado, se acentúa cuando se trata de hábitat, ya que durante estos 10 años la lucha por la propiedad de la tierra y el acceso al suelo siguió siendo descarnada $y$, como en otros órdenes socio-económicos, se resume en el enfrentamiento Estado versus Mercado. 
En este sentido, se abordará el período en dos etapas: la primera (2003-2007), coincidente con el gobierno de Néstor Kirchner, es una etapa de transformación y la segunda (2007- 2013) es una etapa de profundización, que corresponde a la primera presidencia de Cristina Kirchner y los primeros años de su segundo mandato, luego de que fue reelecta en 2011 con el 54\% de los votos.

El gobierno del Presidente Néstor Kirchner dio un giro recentralizador a la política habitacional a través de dos grandes programas de vivienda: "Techo y Trabajo" destinado a la emergencia habitacional y el "Programa Federal de Construcción (PFC)", orientado a la reactivación empresarial de la industria de la construcción. El PFC y "Techo y Trabajo", que dependen del Ministerio de Infraestructura y Planificación Federal de la Nación y de la Secretaría de Urbanismo y Vivienda, coexisten con otras iniciativas provinciales, municipales y del tercer sector, aunque de menor envergadura.

La aplicación de estos programas atravesó varios inconvenientes: la vigencia de la normativa neoliberal de la Ley del Sistema Federal de Vivienda, y la continuidad de programas mantenidos bajo normas, estándares y recursos externos, básicamente del Banco Interamericano de Desarrollo (BID), tanto a nivel nacional como subnacional -PROMEBA, Rosario Hábitat y BID Córdoba, entre otros-.

A partir de estos factores, y del rol del sector de la construcción en la negociación por la aplicación de los recursos (Cravino, Fernández, Wagner y Varela, 2002), los programas recentralizados siguieron aplicando criterios de focalización propios de los '90, sin tener 
en cuenta otros, más abarcativos, de planificación habitacional (por ejemplo, se priorizó la población con NBI, para la cual se financiaron viviendas cuya superficie, calidad de materiales e infraestructura eran mínimas).

Además, se siguió requiriendo mano de obra agremiada en el sector de la construcción bajo la lógica de fomentar su crecimiento en el marco del PFC (que concentra el 70\% de la obra pública realizada en el AMBA) mientras que las cooperativas de vivienda y trabajadores de la construcción cuentapropistas locales quedaron relegados al marco del programa "Techo y Trabajo" -que representaba sólo el 5\% de la inversión estatal en el AMBA- (Rodríguez, Di Virgilio y otros, 2007). Así en la primera etapa de la recentralización, desvinculados de una política integral de acceso al suelo urbano, los programas encontraron muchos obstáculos para funcionar, los cuales se tradujeron en altos índices de subejecución presupuestaria.

Por otro lado, resultaría no solo inexacto sino también injusto analizar las políticas de hábitat popular llevadas adelante en este período (2003-2007) aisladas del conjunto de iniciativas políticas destinadas al mejoramiento de la vida de los sectores populares. Como habíamos señalado, la herencia más grave de la década del 90 fue la destrucción del mercado de trabajo y durante el gobierno de Néstor Kirchner se puso en marcha una exitosa estrategia de recuperación del empleo para incentivar, por un lado, la capacidad de consumo interno y, por otro, el valor cultural del trabajo como organizador de la vida social.

Así, entre 2003 y 2007 la tasa de desempleo disminuyó del 17 \% -22,7 \% si se contabilizan los planes sociales- al 8,5 \% -9.5\% con planes- (EPH, INDEC). En los primeros años, el 
aumento se debió mayoritariamente al sector de la construcción y su reactivación a partir de la inversión pública. Dicho esto, es posible entender por qué la vivienda y la autoproducción del hábitat popular, no fueron objetivos estratégicos de la primera etapa de la reactivación económica argentina.

No obstante, luego de los 90, los sectores populares urbanos tendieron a la denominada producción social del hábitat o autoproducción, de acuerdo al fortalecimiento de las organizaciones sociales y las identidades territoriales de las que hablamos anteriormente. Ello implicó la generalización de dos prácticas socioculturales: la elección y apropiación del territorio que se habita y la organización familiar o comunitaria para la construcción del propio hogar, básicamente, en cooperativas de vivienda. Estas prácticas adquirieron cierta relevancia para el Estado recién en 2006, con la creación de la Secretaría de Tierras para el Hábitat Social, en la que ocupó un lugar preponderante la Federación de Tierra y Vivienda (FTV), cuyo líder, Luis D’Elía, fue elegido Secretario del organismo.

Pero con la inequidad instalada, la migración de nuevos pobres rurales (corridos por el monocultivo de soja pero también atraídos por la reactivación de la industria) y la persistencia de la pobreza, los territorios bonaerenses marginalizados se multiplicaron en el nuevo milenio. Según un informe de la Universidad Nacional de General Sarmiento, a los más de 100.000 habitantes de territorios de exclusión "que se reparten entre 15 barrios de la ciudad de Buenos Aires, se sumó la situación de pobreza y precarización creciente en los partidos del Gran Buenos Aires, en donde predominan los llamados asentamientos originados en 
invasiones organizadas de tierras" (La Nación, 10/07/06). Entre 2001 y 2006 el cordón metropolitano pasó de 385 asentamientos a más de 1.000, lo que equivale al 85\% del total provincial.

La Licenciada Fernández Wagner, a cargo del informe "La emergencia habitacional" (UNGS, 2006), afirmaba que hacia 2006 en las villas de la Capital, el problema está dado por la puja de intereses por la tierra: "Allí, los terrenos son muy caros justamente por estar dentro de un espacio urbano dominante. En cambio, en la provincia, los asentamientos son más espaciados y surgen en terrenos fiscales o tierras privadas que, generalmente, se inundan. Esto es utilizado por los propietarios de los terrenos para obtener un beneficio económico ya que demandan al Estado por las tierras ocupadas (y obtienen así más dinero del que ganarían con la venta de esos terrenos). De esta manera la usurpación se convierte en un gran negocio para todos".

En la segunda etapa, durante la presidencia de Cristina Fernández, la profundización del camino iniciado durante el gobierno anterior, permitió tomar medidas más drásticas en términos de política social. Dos medidas tomadas por Néstor Kirchner fueron centrales para 
crear el nuevo escenario: la renegociación de la deuda externa (con la se logró una quita del 70\%) que hizo posible romper con las imposiciones de ajuste y desregulación económica de los organismos multilaterales de crédito y le permitió al Estado retomar el timón de la política económica. Y la estatización de las Administradoras de Fondos de Jubilaciones y Pensiones, AFJP.

Entre 2005 y 2008, en el sistema de jubilaciones y pensiones comenzó con la ampliación de la cobertura jubilatoria para un número importante de personas con la edad necesaria pero sin la cantidad de aportes requeridos -entre ellos, las amas de casa-, y se profundizó con la estatización del sistema previsional, en manos privadas durante 15 años. En este período, la tasa de cobertura de jubilaciones y pensiones pasó del 45\% de la población en 2005 al 90\% en 2008 (Página/12, 29/07/2010). Con estas medidas, Argentina se convirtió en el país con mayor índice de cobertura jubilatoria de América Latina.

La estatización del sistema previsional -controlado por las AFJP- le permitió a la Administración Nacional de la Seguridad Social (ANSES) disponer de los fondos necesarios para encarar nuevas medidas y retomar así el concepto amplio de "seguridad social" -que trasciende la administración de las cajas jubilatorias y tiene como destinatarios a diversos sectores sociales-. Así surgió la Asignación Universal por Hijo (AUH) .

El 29 de octubre de 2009, la presidenta Fernández de Kirchner anunció la implementación, por decreto del PEN, de la Asignación Universal por Hijo: "Es una respuesta reparadora a la población que ha sido afectada por políticas de corte neoliberal" (www.ncn.com.ar; 
2/11/2009). Actualmente cobran la AUH los hijos de trabajadores informales, desocupados, empleadas domésticas y monotributistas sociales. Son 3,5 millones de chicos y adolescentes hasta 18 años, que integran más de 1,9 millón de familias (www.anses.com; 10/03/2013).

Como surge de estudios cualitativos realizados entre los destinatarios de la asignación, entre los cambios más notorios que produjo la creación de la AUH figuran el aumento del consumo de alimentos, la posibilidad de acceder a una comida extra como la cena, la compra de artículos de limpieza e higiene personal como el dentífrico y la adquisición de útiles escolares y remedios. Pero también generó efectos sociales e individuales más duraderos: la idea de la "gratificación", a través de la compra de postres lácteos y gaseosas, las salidas familiares y los paseos, y el concepto de la "planificación", lo que implica concebir una idea de futuro.

El impacto de la AUH fue importante para el conjunto de las políticas sociales. Según datos de ANSES, en sólo un año de implementación la pobreza había caído el 18\%, y la indigencia el 65\%. Aunque los datos oficiales puedan ponerse en tela de juicio, es innegable que mejoraron las condiciones socio-económicas de los sectores populares, especialmente en Buenos Aires, donde se concentra el 34\% de los beneficiarios. Para acceder a la asignación, el adulto a cargo debe presentar las libretas, escolar y sanitaria, actualizadas. A partir de 
esto, para el período 2010-2011, con respecto al año anterior, la matrícula escolar aumentó un $250^{16}$ y los controles sanitarios un 56\% (según el Ministerio de Salud de la Nación).

El 14 de agosto de 2009, tres meses antes de que se anunciara la Asignación Universal por Hijo, el gobierno de Cristina Fernández lanzó el plan Argentina Trabaja (PAT). Este plan, destinado a los desocupados, se propuso para el primer año la creación de 100.000 puestos de trabajo a partir de la conformación de cooperativas. Hasta ahora, el plan AT tuvo desarrollos heterogéneos en los territorios marginalizados, tanto en su aplicación como en sus resultados. Esto muy vinculado (a criterio de quien escribe) a las altas tasas de empleo informal y economía ilegal que todavía persisten especialmente en estos territorios urbanos. Esta situación obliga, por un lado, al Estado a privilegiar la cantidad por sobre la calidad en términos de cobertura, y por otro, los avances económicos a nivel nacional hacen que las poblaciones marginalizadas estén más excluidas con respecto al resto de la ciudadanía (mayoritariamente sectores medios) y requieran paradójicamente focalizar la mirada para lograr universalizar los resultados de las políticas.

\footnotetext{
${ }^{16}$ Datos arrojados por el sondeo realizado por el Ministerio de Educación de la Nación, sobre una muestra del $60 \%$ de las escuelas públicas de los centros urbanos. Publicado en la página web del MEN con fecha 22/03/2010.
} 
Según datos de la Subsecretaría de Desarrollo Urbano y Vivienda del Ministerio de Planificación, Inversión Pública y Servicios de la Nación ${ }^{17}$ en su "Estado de Avance 2013", en el marco del plan Federal de Viviendas hasta el momento se llevaron adelante 1.076 .430 soluciones habitacionales (construcción de unidades nuevas, espacios colectivos, ampliaciones o mejoramiento de las viviendas existentes) que beneficiaron a más de 4.843 .935 de habitantes, de acuerdo al siguiente detalle:

\begin{tabular}{|c|c|c|c|c|}
\hline PROGRAMAS & TERMINADAS & EN EJECUCIÓN & A INICIAR & $\begin{array}{r}\text { SUBPROGRAMA } \\
\text { TOTAL }\end{array}$ \\
\hline PFREACT I Y II & 28.309 & 2.469 & - & 30.778 \\
\hline PFSH & 36.091 & 7.988 & - & 44.079 \\
\hline PFCV & 193.584 & 80.678 & 15.634 & 289.896 \\
\hline PFCV-Villas & 11.584 & 24.103 & 201 & 35.888 \\
\hline PFMV & 95.842 & 71.744 & 7.832 & 175.418 \\
\hline PFEH & 26.201 & 17.878 & 1.332 & 45.411 \\
\hline PROPASA & 6.082 & - & - & 6.082 \\
\hline PROMHIB & 9.118 & 11.583 & 2.083 & 22.784 \\
\hline
\end{tabular}

\footnotetext{
17 "Plan Federal de Vivienda, Estado de avance al 31/12/2013".
} 
PROMEBA

PROSOFA I Y II

ROSARIO HABITAT *

CARITAS

PF FONAVI **
114.459

49.056

3.683

3.533

192.414
11.355

1.136

682

180

37.328
12.268

$-$

$-$
138.082

50.192

4.365

3.713

229.742

Fuente: Subsecretaría de Desarrollo Urbano y Vivienda, Ministerio de Planificación Federal, Inversión Pública y Servicios.

Complementariamente, se implementó, sobre todo a partir del Banco de la Nación, una línea de créditos hipotecarios para compra de vivienda. Pero la complejidad de la problemática del acceso al suelo urbano que venimos desarrollando, muestra que este fenómeno es multi-causal y no sólo afecta a los más pobres sino también a las capas medias. Los datos que surgen del censo 2010 muestran que los problemas de hábitat en ese año persistían para casi 3 millones de hogares.

El aspecto central, aunque no el único, de esta problemática es el acceso a la vivienda. Para entenderlo, hay tres elementos centrales: El primero se relaciona al mercado de alquileres, siguiendo con los datos de 2010, éstos señalan alrededor de 2 millones de inquilinos en todo el país (muchos de ellos jóvenes de los sectores medios que no pueden adquirir su primera vivienda unifamiliar), para quienes resulta necesario no sólo facilitar 
el acceso a la vivienda propia a través del crédito sino también regular el mercado para evitar la especulación inmobiliaria y el aumento desmedido de los alquileres. En segundo término, hay un déficit de construcción de vivienda para al menos 500.000 hogares y, por último, 1.668.330 hogares con necesidades de reacondicionamiento de la vivienda (Putero, 2010).

Por otra parte, aunque como señalábamos desde la década del 90 hay una suerte de boom inmobiliario, no todas las construcciones son para uso familiar; existe un alto porcentaje de vivienda construidas a modo de inversión y al no existir una regulación contra el suelo improductivo y la vivienda ociosa, los dueños (tanto personas físicas como corporaciones inmobiliarias) ponen precios altos a la espera del mejor postor ya sea para alquiler o venta. Ocurre lo mismo con los terrenos que son comprados y retenidos, provocando una escasez ficticia del suelo en espera de mejores oportunidades. Ante el aumento de la demanda de suelo los precios aumentan y mayores sectores se ven imposibilitados de acceder a una vivienda (Putero, 2010).

En este contexto, en junio de 2012, se puso en marcha el programa de vivienda PRo.CRE.AR. Bicentenario que plantea una intervención diversificada para la problemática del déficit habitacional. El plan prevé la construcción total de 400.000 soluciones habitacionales a través de varios tipos de créditos blandos con bajas tasas de interés (de entre el 2\% y el \%18, sujetas a la variación salarial) y plazos de hasta 30 años. Para Diego Bossio, Director de la ANSES, el programa recupera el crédito hipotecario y señala que "hay que destacar dos 
aspectos centrales de PRO.CRE.AR, por un lado los extendidos plazos, y por el otro, la muy buena tasa de interés" y agrega que "la idea es prolongar esta política de acceso a la vivienda en el tiempo, que sea una política de estado sostenible" (www.anses.gov.ar, $26 / 01 / 2013)$

Una de las líneas es para propietarios de terrenos y otorga créditos para construcción, refacción y/o mejoramiento de viviendas, otra para quienes no poseen terrenos y recientemente se implementó una opción para compra de vivienda única familiar a estrenar. Para el caso de quienes no poseen terrenos, el Estado aportó más de 1.700 hectáreas de tierras fiscales (www.anses.gov.ar, 26/12/12). Además de las líneas de créditos, se llamó a concursos para la construcción de complejos urbanísticos en 42 zonas urbanas del país, lo que a la vez permitiría realizar proyectos con impacto urbanístico en las localidades donde se lleven a cabo.

La iniciativa tiene en cuenta que existe una multiplicidad de necesidades; no sólo se trata del acceso al crédito a largo plazo sino también de planificar la ampliación del suelo urbano habitable e incorporar nuevos terrenos para controlar la especulación del mercado inmobiliario. En este sentido, el concurso convocó a más de 200 empresas constructoras de primer nivel, con un alto grado de competencia en plazas como Córdoba, Mendoza, Tucumán, Comodoro Rivadavia y La Plata, entre otras.

El programa PRO.CRE.AR es aún muy reciente para evaluar cabalmente su impacto pero hasta ahora, pueden decirse de él dos cosas: la primera es que la perspectiva política en la que se 
apoya rompe con la lógica neoliberal y reivindica la intervención estatal por sobre la iniciativa privada en la gestión urbana; la segunda es que en los primeros años no sólo se cumplieron sino que también se superaron los objetivos iniciales: en 2014 ya se asignaron 100.000 viviendas y se realizaron 9 sorteos -en el último ocurrido el 10 de junio, se inscribieron más de 235.000 familias-.

Algunos datos estadísticos interesantes (relevados en 2012 y 2013) son que del total de los destinatarios de los créditos, 44.951 tienen menos de 40 años de edad y 47.070 ganan hasta $\$ 10.000$ mensuales, lo que apoya la tesis de que el segmento social que más se beneficia en esta primera etapa son los sectores medios que aspiran a obtener su primera vivienda unifamiliar.

En los últimos años, se avanzó sensiblemente en políticas habitacionales pero es difícil analizar el impacto en términos estadísticos ya que los datos disponibles son pocos -por ejemplo, los geo-referenciados completos por villa y asentamiento del AMBA más actuales son del año 2006- y no alcanzan a caracterizar las particularidades del proceso diacrónico de cambio. No obstante, las estadísticas sirven para apoyar las tendencias que venimos señalando 
y que dan cuenta de que todavía es necesario profundizar las estrategias de intervención estatal en términos de política habitacional.

Como herencia de los 90 y durante la última década, se gestó una nueva fisonomía urbana en el AMBA en la que las prácticas habitacionales de los sectores pobres contrastan con las urbanizaciones cerradas desarrolladas por los sectores medios-altos y altos de la sociedad. La persistencia de condiciones habitacionales precarias junto con la consolidación de villas y asentamientos, aún en los contextos económicos favorables, dan cuenta del carácter no coyuntural del déficit habitacional: no se han logrado revertir las dificultades que tienen muchas familias para acceder de manera formal a una vivienda en condiciones adecuadas, en suelo urbano bien localizado y con seguridad en la tenencia.

En el caso de la provincia de Buenos Aires, la problemática del hábitat popular se caracteriza por una escasa oferta de tierras aptas para desarrollo residencial. La inversión en propiedades como resguardo de valor ha hecho aumentar considerablemente la demanda de suelo urbano por parte de sectores de altos ingresos y disminuir las posibilidades de acceso para los sectores populares. Asimismo favoreció la especulación inmobiliaria y generó aumentos importantes en los alquileres, excluyendo también de ese mercado a los sectores pobres. El crecimiento económico desde 2003, también contribuyó a incrementar los precios del suelo ya que aumenta la demanda en la periferia por parte de los sectores altos y eso desemboca en el desinterés de los inversores privados en el desarrollo de urbanizaciones populares. 
La legislación argentina sobre hábitat ha ido acompañando las direcciones políticas, aunque a un ritmo lento $y$ en muchos períodos de forma meramente declarativa. La reforma constitucional de 1957 incorporó el derecho a la vivienda digna y la reforma de 1994, en su artículo 41, instituyó el principio del desarrollo sustentable (que lleva implícito el derecho de utilización racional del suelo), así como el deber del Estado y de los ciudadanos a la preservación de los recursos naturales y el patrimonio cultural.

Pero el avance más significativo hasta el momento fue el aporte que hace a la problemática del hábitat la Constitución Nacional de 1949 (llevada adelante por el gobierno Perón) que establecía que: "La propiedad privada tiene una función social y, en consecuencia, estará sometida a los obligaciones que establezca la ley con fines de bien común" (CN, 1949). En 1955 el golpe militar anuló esta Constitución pero tanto el concepto de "función social de la tierra "como esta línea argumentativa, siguieron presentes en la cultura y la política argentina y se retoman en la Ley provincial 14.449. Es por ello que la sanción de la esta ley, reavivó una retórica conservadora política y mediática que colocó al problema del hábitat popular en el lugar de la amenaza a la propiedad y no enfoca el verdadero problema que implica continuar profundizando la distribución injusta del suelo y la sistemática violación del derecho a habitarlo.

La Ley de acceso justo al Hábitat, se presenta, desde su texto, como una ley que viene a dar respuesta a los distintos aspectos vinculados a la problemática de la tierra y la vivienda en la Provincia de Buenos Aires, "incorporando principios rectores, directrices 
generales e instrumentos de actuación que permiten fortalecer la intervención eficiente y justa del Estado para resolver el déficit urbano habitacional, en momentos en los que el gobierno nacional ha tomado la decisión de avanzar en la garantía del derecho constitucional de acceso a la vivienda digna para todos los sectores sociales" (Ley14.449).

En el mismo sentido, se establecen como principios rectores: el derecho a la ciudad y a la vivienda; la función social de la propiedad; la gestión democrática de la ciudad (lo que implica la participación social en la planificación y la gestión de políticas); y el reparto equitativo de cargas y beneficios. Este último punto supone que no serán sólo el Estado ni los sectores populares los que accedan a nuevas viviendas -o a la refacción de las existentes- quienes corran con la inversión que implica la ampliación y el mejoramiento del suelo urbano. Es decir, estas políticas redundan no sólo en una mejor calidad de vida de todos los sectores que habitan las ciudades, sino también en el aumento de los precios de los lotes, lo que favorece directamente a los actuales propietarios y a los desarrolladores inmobiliarios, principalmente pertenecientes a sectores medios y altos, se plantea el "reparto equitativo" de la inversión entre todos los sectores que habitan la ciudad, ya que se todos se verán beneficiados con esta política.

El punto referido al reparto equitativo es el que más reticencia generó por parte de los sectores concentrados de la economía que operan en la zona metropolitana y la Provincia de Buenos Aires: los agentes del mercado inmobiliario, los grandes propietarios de tierras agroganaderas (especialmente las dedicadas al cultivo de soja), los habitantes de countries y 
barrios cerrados y los medios de comunicación monopólicos -que cubrieron todo lo vinculado a la actual Ley 14.449 casi exclusivamente desde el supuesto avance sobre el derecho a la propiedad que supondría la implementación de los artículos 39, 48, 49, 50 y 51 -18.

${ }^{18}$ Artículo 39. - Fondeo del sistema de financiamiento. Establécese, a partir del ejercicio fiscal 2013, una contribución adicional del cincuenta por ciento (50\%) sobre el impuesto inmobiliario total determinado que corresponda a la Planta Urbana Vacante o

Baldíos por aplicación de la Ley Impositiva, cuya recaudación se destinará al Fondo.

Fiduciario Sistema de Financiamiento y Asistencia Técnica para la Mejora del Hábitat.

La Agencia de Recaudación de la provincia de Buenos Aires instrumentará las modificaciones necesarias en sus sistemas para identificar y transferir diariamente el porcentaje de la recaudación del impuesto inmobiliario establecido como de afectación específica en el presente artículo a una cuenta abierta en el Banco de la Provincia de Buenos Aires, que actuará como Fiduciario.

Artículo 48. - Momentos de exigibilidad. La participación en las valorizaciones inmobiliarias sólo es exigible cuando se presente para el propietario o poseedor del inmueble cualquiera de las siguientes situaciones: a) Solicitud de permiso de urbanización o construcción, aplicable para el cobro de la participación en la renta generada por cualquiera de los hechos generadores de que trata el Artículo 45 de la presente ley; b) Cambio efectivo de uso del inmueble, aplicable para el cobro de la participación en la renta generada por la modificación del régimen o zonificación del suelo; o c) Actos que impliquen transferencia del dominio sobre el inmueble en forma total o parcial, con excepción de aquéllos resultantes de herencias y donaciones sin cargo, aplicable al cobro de la participación en la renta de que trata el Artículo.

Artículo 49. - Formas de pago. La participación en la renta urbana puede efectivizarse mediante cualquiera de los siguientes medios, siendo ellos de aplicación en forma alternativa o combinada:

a) En dinero efectivo, que será destinado exclusivamente a la construcción o mejoramiento de viviendas y/o construcción de obras de infraestructura de servicios públicos y/o de áreas de recreación y equipamientos sociales en sectores de asentamientos o viviendas de población de bajos recursos; 


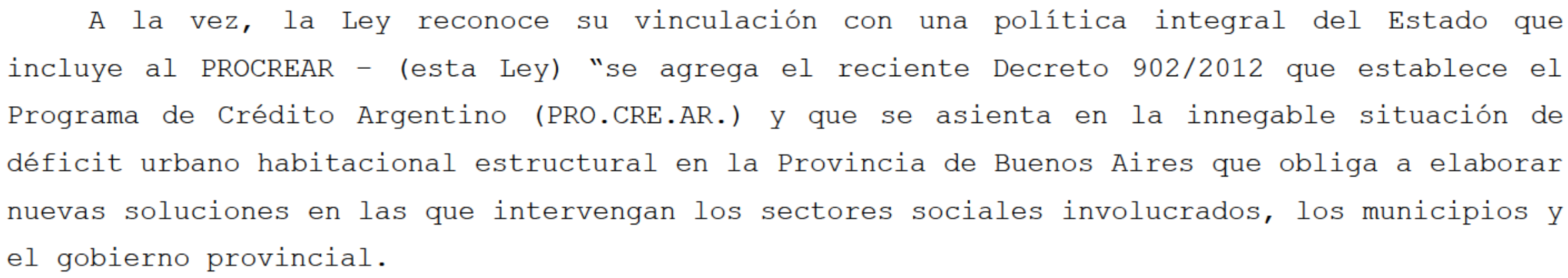

b) Cediendo al Municipio una porción del inmueble objeto de la participación, de valor equivalente a su monto; o c) Cediendo al Municipio inmuebles localizados en otras zonas del Área Urbana y/o Complementaria, accesibles desde vía pública y conforme a los criterios de localización adecuada establecidos en el Artículo 15, apartado a) de la presente ley, previo cálculo de equivalencia de valores entre ambos emplazamientos, incorporando las valorizaciones producidas por la aprobación del emprendimiento y por la modificación de la norma urbanística que se requiera.

\section{Artículo 50. - Contribución obligatoria sobre la valorización inmobiliaria.}

Los municipios deberán establecer por una Ordenanza de carácter general una contribución obligatoria no inferior al diez por ciento (10\%) de la valorización inmobiliaria generada por los hechos enunciados en el artículo 46 de la presente ley, con ajuste a los criterios de exigibilidad y pago establecidos precedentemente.

Artículo 51.- Grandes desarrollos inmobiliarios. Determinación presunta y pago a cuenta. Los sujetos obligados al pago de la contribuciónestablecida por el Municipio en que se que desarrollen los emprendimientosindicados en el artículo 46 inciso f) de la presente ley, tales comoemprendimientos de clubes de campo, barrios cerrados y toda otra forma deurbanización cerrada; o cementerios privados o de emprendimientos degrandes superficies comerciales, quedando incluidos en esta última categoríalos establecimientos que conformen una cadena de distribución según loestablecido en la Ley 12.573 y su reglamentación, siempre que ocupen prediosde más de cinco mil metros cuadrados (5.000 m2.), sin importar el área o zonadel ejido municipal en la que se instalen, de acuerdo a lo dispuesto en losincisos b) y c) del artículo 49 , cederán como pago a cuenta de la determinacióndefinitiva, sujeto al cómputo de equivalencia y valorización final, el $10 \%$ de lasuperficie total de los predios afectados o sus equivalentes en dinero o suelourbinazable. 
En el mismo sentido, se revisa cómo en los últimos años se ha acrecentado y densificado la población en villas y asentamientos, a la vez se produjo una fuerte concentración de la renta urbana que se materializa a través de la realización de prácticas especulativas de los desarrolladores y propietarios, lo que resulta en una gran cantidad de inmuebles deshabitados y terrenos baldíos, que podrían ser aptos para edificación pero que se encuentran retenidos a la espera del aumento del valor del suelo. Como dice la Ley, estas prácticas especulativas crean un clima artificial de escasez de tierra urbanizada que hace que los valores de mercado del metro cuadrado se incrementen incluso por encima del precio que poseían durante el período de dolarización de nuestra economía y generan aumentos en el precio del suelo que superan toda lógica, "afectando principalmente a los más jóvenes que se ven imposibilitados de acceder a su primera vivienda" (Ley 14.449).

En algunas zonas de la región metropolitana, en los últimos 8 años, el valor del suelo se incrementó más de un 360\%, fenómeno ligado a la falta de acceso al crédito, de acceso al mercado formal de alquileres, de una ineficaz estrategia de inversión pública y de erradas políticas y normas urbanísticas. En ese marco, las ocupaciones de tierras constituyen en la historia reciente la forma más común de acceso al suelo para los sectores populares, generando que en el AMBA 6 de cada 10 personas que compran un lote o alquilan, lo hacen en el mercado informal.

Desde este punto, la Ley de Acceso Justo al hábitat reconoce que resulta insuficiente encarar el problema con meras políticas de construcción de vivienda social a través de 
empresas constructoras, y que es necesario intervenir prontamente en el mercado de suelo urbano como lo hacen por ejemplo Brasil (a través del Estatuto de la Ciudad) o Colombia (con la Ley $\mathrm{N}^{\circ} 388 / 97$ de desarrollo urbano).

Según los legisladores provinciales, el rol del Estado debe ser activo para encarar una acción de planificación, que reconozca derechos y obligaciones y marque el rumbo presente y futuro ya que el grave déficit habitacional se debe principalmente a "la gran timidez que poseen los instrumentos utilizados para incidir sobre los precios del suelo" (Ley 14.449).

La Ley 14.449 fue aprobada el 29 de noviembre de 2012, el Ejecutivo Provincial aún no dispuso su reglamentación. 


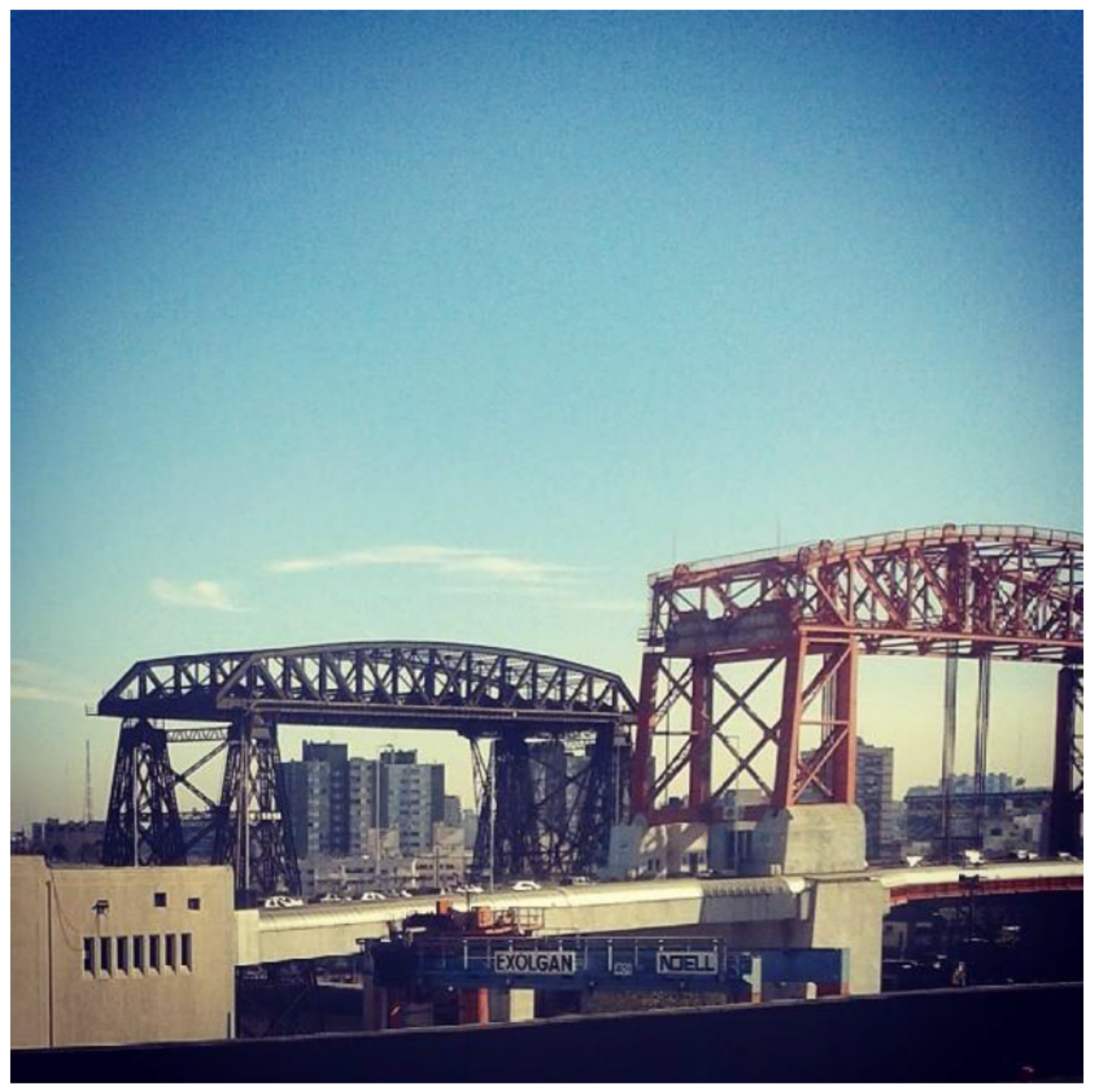

Capítulo IV 
Esta tesis se propuso estudiar procesos de exclusión y estigmatización territorial con el fin de aportar información útil a las políticas de urbanización de barrios marginalizados en el AMBA, especialmente los de la zona sur, linderos a la cuenca Matanza - Riachuelo. Para eso, se implementó un diseño metodológico apoyado en enfoques, nociones y técnicas tradicionales de la etnografía y el análisis cultural: la entrevista en profundidad, la semiestructurada y la observación participante, como también el análisis por ejes conceptuales de documentos históricos, políticos y jurídico-legales.

El enfoque cualitativo no se define por oposición a lo cuantitativo -de hecho en este trabajo se incorporan como fuentes secundarias distintos datos estadísticos y se realizó una primera sistematización cuantitativa de las entrevistas semi-estructuradas-, sino que implica que todos los datos se interpretan y analizan cualitativamente; tanto los provenientes del trabajo etnográfico, como los datos estructurales recabados en la investigación documental.

La focalización de la muestra para el trabajo etnográfico se hizo en los barrios Isla Maciel y La Boca, ya que estudiarlos en interacción permitió incorporar al análisis algunas particularidades de los territorios marginalizados del Primer Cordón del Conurbano bonaerense, de la zona sur de la Ciudad Autónoma de Buenos Aires y de las problemáticas habitacionales y ambientales de la cuenca del Riachuelo. 
Es necesario aclarar que mis preguntas de investigación siempre se orientaron a desentrañar problemáticas vinculadas a procesos de marginalización social, en ese marco, vengo realizando trabajos de campo más o menos sistemáticos en la Isla Maciel desde el año 2005. Por eso, la observación participante en este barrio fue la técnica fundamental de la tesis y, a la vez, la participación en el territorio excedió los límites de este estudio. De acuerdo a esto, la observación se concibió como una técnica flexible, no predeterminada -ni antes ni durante el proceso de investigación- por lo que los observables fueron mutando, volviéndose más nítidos o difusos.

Entre 20005 y 2010 participé en diversas actividades barriales que me permitieron asistir bastante regularmente y tomar las notas de campo correspondientes. Durante ese período tuve la oportunidad de establecer vínculos personales con varios vecinos y vecinas que funcionaron como informantes clave y/o simplemente como una puerta de entrada al barrio. Entre 2008 y 2010 realicé una serie de 40 entrevistas semi-estructuradas de aproximación y entre 2010 y 2012 cinco entrevistas en profundidad, en ellas la periodicidad de los encuentros dependió en gran medida de la disponibilidad de los entrevistados.

El modo de establecer los perfiles prioritarios para las entrevistas en profundidad no fue sólo el criterio de los vínculos con informantes clave, también se siguió un razonamiento similar al planteado por Pierre Mayol en su investigación sobre el barrio y la vida cotidiana: "Con razón o sin ella, preferí confiar sólo en algunos personajes los elementos esenciales de la investigación, al acumular tras ellos los frutos de una prospección en un 
área de relaciones más amplias" (De Certeau, Giard, Mayol; 2006). En esta investigación Mayol decide tomar como informantes a una sola familia del barrio de la Croix-Rousse, del que además es oriundo. Aunque no analiza las relaciones familiares entre los miembros (ya que sus preguntas de investigación no lo requieren) sino que focaliza en el modo en cada uno experimenta cotidianamente el barrio ${ }^{19}$.

Durante los años 2010 a 2012, la observación participante no se interrumpió completamente, pero no fue sistemática ni prioritaria en términos metodológicos -la confrontación con el referente empírico sirvió para establecer y confrontar categorías de análisis de datos-.

Por último, en 2012 y 2013, se estableció una segunda etapa de observación del campo y se incorporaron observaciones en el barrio de La Boca. Estas, apuntaron básicamente a contrastar, revisar y ampliar los datos obtenidos hasta el momento, y a la vez permitieron profundizar la perspectiva relacional para la interpretación y el análisis, en la Boca también se realizó una serie de 20 entrevistas semi-estructuradas.

${ }^{19}$ Con relación a los criterios de definición de los informantes seleccionados para las entrevistas en profundidad, también se retomó de este trabajo de Mayol la idea de: “(...) privilegiar a las personas mayores y a los adultos en la medida en que el tiempo invertido en el espacio facilita uno de los ejes de la investigación, el problema de la apropiación" (De Certeau, Giard, Mayol; 2006). Por otro lado, se eligió no soslayar la voz de los jóvenes, ya que este grupo tiene algunas características culturales - que son estudiadas de forma diferencial desde las ciencias sociales-, que lo vuelven relevante; aunque éste no pretende ser un estudio sobre juventud/es, sino abarcar el abanico más amplio posible de tipos de sujetos sociales que viven en el territorio y participan de sus redes organizacionales. 
No sólo aquí sino en todos los estudios sociales cualitativos, los rasgos específicos del trabajo etnográfico siempre evolucionan a medida que operan, la dinámica de ese proceso se apoya -o es esperable que lo haga- en las nociones de vigilancia epistemológica de Pierre Bourdieu y de reflexividad en la observación participante de Rossana Guber. La primera explica que el científico debe rever continuamente los supuestos epistemológicos de su investigación, prenociones teóricas y metodológicas, a partir de su interacción con la realidad empírica (Bourdieu, 1990); y la segunda asume que la participación del investigador en el territorio es una herramienta valiosa para el conocimiento social, pero no por su neutralidad, que es por definición imposible, sino porque se evitan subjetividades interpretativas de posibles intermediarios (Guber, 1991). Así, el investigador o investigadora debe ser quien contraste y ponga en diálogo críticamente la teoría con la realidad del referente empírico (Vidarte Asorey, 2008).

Para diseñar e interpretar los distintos tipos de entrevista se retomaron aspectos de la reconstrucción de trayectorias, historias de vida y relatos de vida (Larrañaga, 2009); como así también del método biográfico, constituido a partir de la combinación de dos estilos de conducir las investigaciones: el método biográfico interpretativo, propio de la tradición interpretativista en la investigación sociológica, y el método etnográfico antropológico, focalizado en la observación y en la descripción de trayectorias insertas en determinado contexto social (Sautu, 1999). 
En síntesis, a partir de un diseño metodológico basado fundamentalmente en la investigación documental y el trabajo de campo, esta tesis buscó responder a la pregunta por los procesos de marginalización socio-territorial, no sólo para caracterizar las particularidades de la relación hábitat / habitus en un espacio y un tiempo determinados, sino también para aportar propuestas a las políticas de urbanización de villas y asentamientos en el AMBA. A lo largo del proceso de tesis, se produjeron 60 entrevistas semiestructuradas, 5 entrevistas en profundidad e innumerables charlas informales. Todas ellas conforman el corpus de narrativas que se analizaron para identificar los sentidos colectivos asignados a la experiencia de habitar el territorio urbano. De ello es que trata de dar cuenta en este capítulo.

En la configuración del imaginario sobre los fenómenos sociales ligados a la marginalización urbana, el miedo -asociado a la violencia en clave de inseguridad- funciona como uno de los ejes estructurantes de los procesos de estigmatización y la discriminación. Por eso, es habitual que los análisis y las interpretaciones entiendan al miedo como una 
categoría no sólo insoslayable sino también central. También en esta tesis se aborda el entramado miedo/violencia/inseguridad para pensar el mapa interactivo de sentidos y actores en los territorios segregados. Así, las descripciones y opiniones obtenidas en el trabajo de campo se sistematizaron según tres grandes categorías: espacio tópico (el habitado), heterotópico (el que genera miedo y discriminación) y utópico (el del orden de lo ideal); estos tres conjuntos de sentido son los que propone la antropóloga Rossana Reguillo para estudiar la violencia territorial (Reguillo, 2008).

Entonces, de acuerdo a los conjuntos de narrativas obtenidos y al objetivo general de la investigación -aportar herramientas para la planificación de políticas de reurbanización transformadoras- se indagaron e interpretaron los sentidos en torno al miedo en clave de su gesto opuesto: la esperanza ${ }^{20}$; analizando tanto los factores que generan hechos delictivos y los que aumentan la percepción de inseguridad como también aquellos que los vecinos refieren como factores que los hacen o los harían sentir más seguros.

Por ejemplo, al ser consultados sobre los días y horarios más inseguros, muchos vecinos del barrio de La Boca señalaron con más o menos énfasis que la mañana es el horario más seguro y la noche el más inseguro: "... puede ser, hay horarios como la noche (que son más inseguros) pero si sos del barrio es tranquilo" dice un joven de 21 años y un hombre de 66 explica "... a partir de las 12 de la noche la gente sale a consumir drogas, alcohol, entonces

\footnotetext{
${ }^{20}$ Reguillo, R. (2011) Charla Magistral, Doctorado en Comunicación, FPyCS - UNLP.
} 
te da miedo salir...". "Y, lógicamente... después de las 2 de la tarde es inseguro (...) Ahora que empezó el colegio hay más gente, pero sino no podes salir", advierte una mujer de 75, "Igual que en cualquier otro barrio de Buenos Aires o de la Argentina. Sí, hay horarios, a las 3 de la madrugada salís a caminar y si, te vas a sentir más inseguro".

Las respuestas permiten claramente vincular el miedo y la sensación de inseguridad con la noche, la oscuridad y la falta de circulación de gente. Pero esta tesis intenta ir más allá del análisis de datos y categorías conceptuales para traducir ese análisis en acciones concretas en el marco de las políticas de reurbanización -como se desarrolla en las conclusiones-. Así, la vinculación directa entre inseguridad y territorio oscuro y despoblado nos permite identificar la importancia de la inversión en infraestructura barrial, especialmente la iluminación de calles y caminos, así como la puesta en valor de los espacios públicos existentes y la producción de nuevos espacios de interacción comunitaria.

Decíamos que la inseguridad urbana es un fenómeno complejo que se constituye tanto por los tipos y la cantidad de hechos delictivos, como por las experiencias vividas y los sentidos construidos en torno a ellas. Así, para arribar a conclusiones -o al menos a nuevos puntos de partida- que contemplen la configuración relacional del fenómeno de la marginalización urbana y a la vez se constituyan en herramientas de intervención que incidan en el plano material y cotidiano de la experiencia comunitaria, analizamos los sentidos colectivos que aparecen en las entrevistas pero también las prácticas y los datos duros sobre cantidad y calidad de hechos delictivos ocurridos en el AMBA. 
Sobre la relación entre estas dos dimensiones constitutivas de la inseguridad (el delito y la percepción), para la reedición de su libro Los Pibes Chorros, Daniel Míguez explica que mientras durante "los años 90 se habían producido asociaciones entre las transformaciones de la estructura social argentina y la evolución del delito" -el aumento de la desocupación y la pobreza fue acompañado de un alza inédita en la inseguridad-, entre 2003 y 2010 no ocurrió lo mismo: las tasas del delito disminuyeron considerablemente pero la percepción pública del problema no acompañó estas evoluciones (Míguez, 2010).

Para realizar esta comparación, Míguez retoma dos tipos de fuentes estadísticas: la Encuesta Nacional de Victimización (ENV), que se realiza en cinco ciudades del país a muestras representativas del total de las poblaciones urbanas analizadas, y los índices del Sistema Nacional de Información Criminal, que se construyen a partir de los datos que surgen de denuncias policiales realizadas en todo el país.

En esta tesis, se incorporan también los datos obtenidos por el Instituto de Investigación en Homicidios Dolosos (IIHD) de la Corte Suprema de Justicia, que no abarca una cantidad de casos tan masiva como la ENV y el SNIC ${ }^{21}$, pero revisa los homicidios dolosos

\footnotetext{
${ }^{21}$ Se toman en cuenta los tres informes presentados por el Instituto de Investigación en Homicidios Dolosos (IIHD) de la CSJN: El primero corresponde al año 2010 y se limita a los homicidios cometidos en la Ciudad Autónoma de Buenos Aires; el segundo, sobre el año 2011, extiende la investigación a los departamentos judiciales de San Martín y La Plata; por último el tercero, acerca de los hechos cometidos en 2012, abarca los cometidos en la Ciudad Autónoma de Buenos Aires y los municipios de primero, segundo y parte del tercer cordón del Conurbano Bonaerense.
} 
cometidos en una población total de más de catorce millones de personas (el equivalente a un tercio de la población argentina) en la zona de mayor conflictividad, la CABA y el Conurbano bonaerense.

A la vez, el IIHD de la CSJN incorpora las variables de la investigación judicial que dan cuenta con mayor profundidad de las características de los hechos delictivos y de sus tramas de interacción social (motivos, relación entre víctima y victimario, etc.) y provee datos cualitativos geo-referenciados. Esto último permite identificar de manera clara los territorios en los que se cometen más homicidios dolosos y deja en evidencia que los barrios más pobres son, efectivamente, los más violentos y en ellos se producen la mayor cantidad de muertes. No obstante esto, el AMBA no es una metrópoli especialmente violenta.

Durante el año 2012, tomando como referencia los homicidios dolosos cometidos en Buenos Aires, La Plata y el Conurbano, el número total de víctimas fue 995, es decir una tasa por 100.000 habitantes de 6,93. El IIHD coincide con el citado planteo expuesto por Míguez (2010) ya que señala que "en relación con las tasas de Europa y Canadá es alta pero en relación con las de los países latinoamericanos es en general baja, junto con las de Uruguay y Chile" (IIHD, 2012).

El hecho de que la percepción de inseguridad y el miedo hayan aumentado aun cuando esto no surja del aumento real del delito se debe a muchos factores; probablemente uno de los principales es la construcción mediática de la inseguridad. Esa construcción se impuso en 
Argentina durante la segunda mitad de la década del 90, al mismo tiempo que en muchos países del mundo occidental, acompañada de la doctrina de la Tolerancia Cero (Wacquant, 2001) y la tendencia a las políticas de mano dura. ${ }^{22}$

Otro de los factores a tener en cuenta es la aparición de nuevas modalidades delictivas más violentas. Como también expone Míguez, en el siglo XxI -sobre todo a causa de los cambios en la estructura de las redes delictivas internacionales, como el narcotráfico y la trata de personas- variaron los tipos de delito. Así, aparecieron modalidades más violentas, a menudo asociadas con la intervención de menores y de drogas altamente nocivas, como el paco en Argentina. Estas nuevas modalidades generan nuevos miedos y, a su vez, alimentan la construcción mediática dominante que asocia al delincuente / criminal con el joven, varón, pobre (Kessler, 2004).

Pero los hechos delictivos reales muestran que, en el universo total del delito, los menores que participan son aproximadamente el 4\% y menos del 1\% de ellos cometen homicidios dolosos. Según desentraña la investigación del IIHD, la mayor parte de los delitos violentos suceden en la zona sur de la ciudad de Buenos Aires y en los barrios más pobres del Conurbano. Así, los jóvenes -que son sindicados por algunos entrevistados como los que

\footnotetext{
${ }^{22}$ La Doctrina de Tolerancia Cero surge en Nueva York, durante la gestión del Alcalde Rudolf Giuliani. Su caracterización se amplía en el Capítulo I, pera ampliarla puede consultarse "Imaginario social del delincuente, la justicia y el crimen en los relatos policiales argentinos 1950-2000" (Vidarte Asorey, 2007). Informe final Beca de Iniciación a la Investigación UNLP (2005-2007).
} 
delinquen y están drogándose a la noche en las esquinas- están expuestos a una violencia mayor que otros actores sociales, aunque no necesariamente es provocada por ellos.

Sobre el tema de la violencia y volviendo al ejemplo anterior, en el que habíamos identificado en las entrevistas una constante que relaciona directamente inseguridad / noche / territorio solitario, así como hablamos de la iluminación y la infraestructura como elementos positivos para la urbanización, del mismo modo, podríamos pensar en la presencia policial para evitar las calles desoladas. Pero en los territorios estudiados, es importante contemplar que los sujetos sufren muchos hechos de inseguridad por parte de la Policía (abusos de autoridad, desalojos violentos, gatillo fácil, etc.), por lo que la presencia policial concita muchos sentidos negativos en las comunidades.

En los barrios estudiados, gran cantidad de los delitos son cometidos por la Policía o, al menos, con la complicidad de redes delictivas policiales. En este sentido, un hombre de 56 años vecino de la Isla Maciel señala que el peor problema del barrio es: "la Policía, porque dan ventajas a todos los que son sinvergüenzas, a los que venden droga. Los límites y la ley en la calle, ellos saben porque ellos andan en la calle todo el día y saben dónde está la droga, quién la vende, y ahí está el arreglo. Así que si la policía cambia, las cosas podrían cambiar (...) Está el jefe de calle, está el segundo, el tercero, están pero están todos corrompidos, todos agarran la guita". 
Es clave el tema de la corrupción policial, la violencia institucional y las redes delictivas policiales como actores centrales en la gestión territorial de la violencia cotidiana y los hechos delictivos. Por esto, no es extraño que los entrevistados en general no se refieran a las policías (Bonaerense y Federal, según el barrio) como actores que favorecen la seguridad barrial.

No obstante, hay que resaltar que varios entrevistados señalan a otras Fuerzas, específicamente Gendarmería y Prefectura, como actores cuya presencia les otorga confianza y seguridad: "Acá en esta zona (Caminito) me siento seguro, porque ahora está la Prefectura.", "Donde yo vivo me siento muy segura, estoy al lado de Prefectura", "... ninguna zona del barrio me hace sentir más segura, el barrio en sí es muy seguro, hay gendarmería en todas las esquinas.", "Lo que cambio mucho (en La Boca) es la seguridad con Prefectura, antes estaba la Policía Federal y ahora se ve mayor cantidad de vigilancia, al menos, y que pusieron cámaras de seguridad."

En líneas generales, las entrevistas mostraron que la construcción de sentido en torno a la percepción de inseguridad no responde unilateralmente al discurso mediático. Si bien en algunos casos, al ser consultados sobre cuáles son los barrios más inseguros, la construcción estigmatizante de los medios masivos es reproducida de forma acrítica: "Con esta inseguridad que hay ahora no creo que haya un barrio que no sea inseguro, es difícil, porque uno no sabe dónde te van a atacar. Hay que tener cuidado", "sé que las villas son peligrosísimas (...) En la televisión se ve que la delincuencia es alta, te roban, te matan"... "Es una pena que el 
delincuente haya llegado al extremo de matar por un celular (...) Deberían cambiar las leyes, para el ciudadano". Es decir, como en el caso de autor de esta última frase, un hombre de 66 años, algunas narrativas dejan en evidencia que la televisión actúa como principal fuente de información -y en algunos casos la única- en la que se apoyan las narrativas sobre inseguridad y, en consecuencia, la base de sentidos de los procesos de estigmatización.

Es innegable que los medios masivos tienen una posición de dominante con capacidad de agencia en la cultura popular y propician la construcción de imaginarios estigmatizantes. No obstante, la mayoría de los entrevistados reproduce sólo en parte el discurso mediático -e incluso lo contradice- e incorpora nuevos elementos vinculados a la experiencia de vida en el territorio: "Un barrio muy inseguro es Almagro, lo sé porque tengo un hermano que vive por ahí", "Yo paso por Constitución constantemente y gracias a Dios nunca me robaron. Tengo compañeros que viven en Once y nunca pasó nada", "Si te sabes manejar es un barrio que tiene códigos, que no se mete la gente del barrio con la gente del barrio (...) Por acá no vas a escuchar de robos a personas mayores o disparates como se escuchan de otras zonas", "Muchos dicen que la inseguridad es latente pero yo camino el barrio a cualquier hora y todo el tiempo, nunca en lo personal ni a ninguno de mis allegados le ha afectado la supuesta inseguridad como dicen los medios que está", "Yo camino el barrio a cualquier hora y mismo mi familia, mis hermanos y no notamos ese grado de inseguridad como dicen que hay", "No, no sé qué contestarte (...) Muchos dicen que La Boca o Barracas son peligrosos pero a mí las dos veces que me quisieron robar fue en Plaza Francia", "La inseguridad está las 24 horas. (...) Te 
pueden robar acá o en pleno Palermo Soho, por ejemplo, que es uno de los lugares más robados que hay en Capital Federal. Y sin embargo son los lugares más vigilados, con más cámaras y son los lugares más robados", "Para mí los peores barrios son los de las altas esferas, como Nuñez, La Recoleta", "... vos caminás por acá y no te pasa nada. Por ahí te vas a la zona cheta de Retiro y te terminan robando ahí. Te vas caminando por la calle Juncal y te roban. Por más de que sea muy bonito y eso".

Es decir, no se pretende negar el rol de los medios concentrados, y su capacidad no sólo de imponer agenda sino también de operación discursiva para crear un escenario en el que, según Zaffaroni (2011), la sociedad se divide entre un "nosotros" conformado por la gente decente de las clases medias y altas (que se identifica al público destinatario construido por el medio) y unos "otros" delincuentes y criminales, excluidos no sólo por su pobreza sino por su resentimiento y su desprecio por la vida y la moral social.

Ocurre que este escenario en blanco y negro, no opera con la misma verosimilitud entre aquellos que habitan territorios estigmatizados. Por lo tanto, el discurso mediático se diluye entre otras mediaciones del sentido como la identidad y la experiencia. Así lo explican los vecinos de Isla Maciel: "Lo que pasa que la gente se cree lo que le manda la tele, que acá son todos chorros, drogadictos", "Te pintan una realidad de las villas que no es así, pero lo que vende es pasar los pibes chorros, la miseria", "No te van a mostrar que acá somos como todo el mundo, que tenemos cumpleaños, momentos de familia, que nos reímos". 


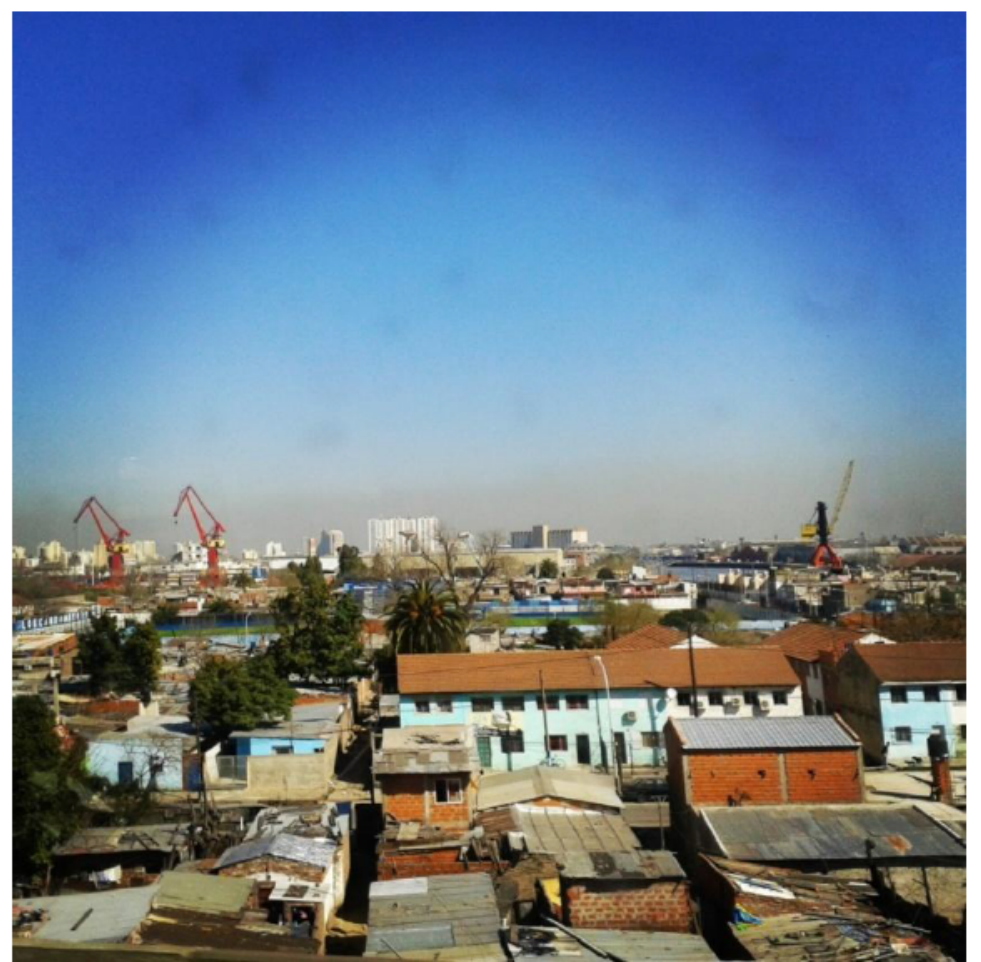

Desde la perspectiva de la comunicación y la cultura, los procesos de discriminación, como el miedo, son inherentes a la interacción social: los y las humanas tenemos la capacidad de simbolizar, objetivar y transmitir la experiencia produciendo acervos culturales de sentido que nos permiten interactuar con otros y con el ambiente (Vidarte Asorey, 2008). 
Por eso, el miedo a estar en peligro anteceda al hecho peligroso como operación lógica, aunque esto no las convierte en inocuas o justas. Estas pautas de acción se encabalgan en procesos en los que operan en tensión múltiples actores dominantes y subalternos que producen, reproducen, resisten o resignifican el acervo cultural. Así es posible indagar esos procesos, para intervenir en los escenarios en los que se producen y cambiar la ecuación de poder a favor de las clases populares pero para eso es necesario entender que hay grises, hay grados de estigmatización y los estigmatizados también pueden ser estigmatizadores.

Como se dijo, los criterios operantes en la percepción de inseguridad de los vecinos de los barrios de La Boca e Isla Maciel contradicen e interpelan el discurso mediático dominante, tanto con relación a la experiencia de habitar un territorio estigmatizado, como a los territorios y sujetos elegidos para estigmatizar. Si analizamos las descripciones obtenidas en el trabajo de campo, de acuerdo a las categorías que propone la antropóloga Rossana Reguillo para estudiar la violencia territorial: espacios tópicos, heterotópicos y utópicos; encontramos que para estos vecinos y vecinas los sentidos que definen lo heterotópico, aquellos que se ponen en juego en los procesos de estigmatización social y territorial, se asocian sobre todo a la experiencia, la opinión subjetiva, intersubjetiva o comunitaria y a prejuicios arraigados históricamente en el imaginario, incluso anteriores al discurso mediático.

“... ¿si pudiera mudarme a cualquier barrio, cuál elegiría? De la Provincia ninguno, no cruzo más el charco. Viví 10 años en Ranelagh, sudándola para hacer mi casa. Cuando vi que se venía 
toda la gronchada, (como) tengo tres hijas mujeres que eran chicas, ahí dije no, vamos a la capital de donde soy". La referencia al Conurbano como espacio heterotópico apareció de forma recurrente, tanto en los vecinos de La Boca que se manifestaban afuera de ese territorio marginal, como por parte de los vecinos de la Isla Maciel que situaban en La Ciudad, específicamente en La Boca, los sentidos asociados al espacio utópico (aquel que les gustaría habitar o en el que se sienten cómodos o a gusto al transitarlo) en oposición al territorio que habitan: "Siempre me gustó más la capital que la provincia, ¿la zona más insegura de la ciudad? Por ahí por Lanús, el Conurbano es lo más jodido", "De los barrios que yo conozco, los más inseguros son Ituzaingó, Dock Sud y también Flores".

Pero también dentro del propio barrio, se establecen diferencias entre espacios o zonas, basadas en criterios que habilitan el proceso de marginalización. Así lo explica, por ejemplo, un vecino de La Boca de 78 años de edad: "Para los que vienen de afuera hay zonas que son intransitables. Las mejores zonas de antes, las cantinas, etc. ahora son las más inseguras. Toda la parte de (la calle) Necochea, ahí está todo tomado. Antes eran todos italianos, todos españoles, ahora es una villa", "Necochea no es recomendable. No conozco mucho pero por Necochea puede ser peligroso", dice otro vecino del barrio de 68 años, y una vecina de 75 refuerza la idea: "La zona que menos me gusta es entre Olavarría y Suarez, es fea. Esa zona todavía no se ha renovado, es la zona donde estaban las cantinas antes, que están cerradas y han sido tomadas". Y siguen las narrativas en el mismo sentido: "Hay partes, 
por ejemplo el barrio Chino, que no me gustan, no tiene buena fama. Según dicen, lo peor es pasando Almirante Brown, yendo hacia Necochea".

Las calles (Almirante Brawn, Necochea, Suárez, Olavarría, Lamadrid, etc.) y sub-barrios (barrio Chino, las cantinas, el Bajo) que estos vecinos indican como inseguros o peligrosos son las zonas más marginalizadas del barrio de La Boca. En este sentido, frente a la misma pregunta por las zonas más inseguras, la mayor parte de los entrevistados, no sólo identifica estas zonas como estigmatizadas sino que además reflexiona sobre las causas del proceso de marginalización: "No me gusta el bajo, la parte donde está el asentamiento Lamadrid no me gusta por la cuestión habitacional de la gente por cómo vive", "Las zonas marginales me gustan poco porque no se le da importancia", "La crisis Habitacional, sería eso lo primero que yo trataría de subsanar", "Que saneen el Riachuelo y hagan costanera (...) que draguen, si no dragan no hay oxígeno y si no hay oxígeno no se puede pescar", "obviamente mejoraría la infraestructura, dejaría todo como está arquitectónicamente, pero dentro de los Conventillos, dentro de las casas la estructura es muy carenciada", "La semana pasada hubo dos o tres incendios bastante importantes donde los vecinos tuvieron que dormir el sábado y el domingo, que hubo mucho frio, con un fogón (...) Entonces hay que cambiar la calidad de vida de los vecinos", "Hay lugares que suelen ser más peligrosos pero por un tema social, pero no deja de ser lindo igual. Ya ahí nos metemos en otro tema: la pobreza, la marginación, pero no deja de ser La Boca", "... es que la contención del barrio no pasa por las calles, ni hacer bicisendas ni colocar lindas veredas. Hay gente que tiene otro tipo y clase de necesidades, contención 
social, trabajo, salud. Me parece que pasa más por ahí (...) por la parte social, o sea, podes tener veredas hermosas y tener pibes que se están cagando de hambre, entonces, las veredas no sirven de mucho".

También para los vecinos de Isla Maciel, las cuestiones habitacionales y ambientales son identificadas como causas centrales de los procesos de exclusión territorial y, a la vez, principios básicos e ineludibles para transformar esos procesos: "El cambio más importante fue cuando llegó el agua (potable en red) y después cuando rellenaron (el terreno), porque acá era muy bajo y se inundaba un montón", "... me gustaría que mejoren las calles, las viviendas", "Para mí en el futuro habría que mejorar las casas, los terrenos".

Pero mientras los habitantes de La Boca mencionan los problemas de hábitat y ambiente al referirse al espacio heterotópico (territorios marginalizados), los de la Isla Maciel lo hacen al caracterizar el espacio tópico (territorio habitado). Así, las referencias al proceso de marginalización territorial y ambiental no surgen de preguntas por la inseguridad, sino de preguntas relacionadas con la esperanza y el futuro: "En el futuro lo que hay que mejorar es la parte ambiental". Ya en 2008 un vecino explicaba: "El ambiente es una necesidad. Acá tenemos un arroyo que viene de la cuenca del río Matanza que hace años está el 
proyecto del entubamiento y no se hace. La gente que vive ahí, al costado, se está comiendo toda esa enfermedad, día tras día. Esa es la mayor necesidad que tenemos para el futuro"23.

Hablando directamente sobre la zona más marginalizada dentro de Isla Maciel llamada el Fondo $^{24}$, que hasta 2010 se extendía entre el basural lindero al arrollo (actualmente

\footnotetext{
${ }^{23} \mathrm{~A}$ mediados de 2009, se puso en marcha el proyecto de entubamiento del arroyo. La obra pública se coordinó con trabajos de mantenimiento barrial realizados en el marco de la contraprestación del Plan Argentina Trabaja, así vecinos del barrio limpiaron los basurales de las orillas y prepararon el terreno para que la cuadrilla de obreros comenzara el entubamiento. Para octubre de 2010, el trabajo estuvo terminado.

${ }^{24}$ La siguiente imagen es una fotografia de una pintada en una pared del barrion que reproduce el plano de la Isla Maciel:
}

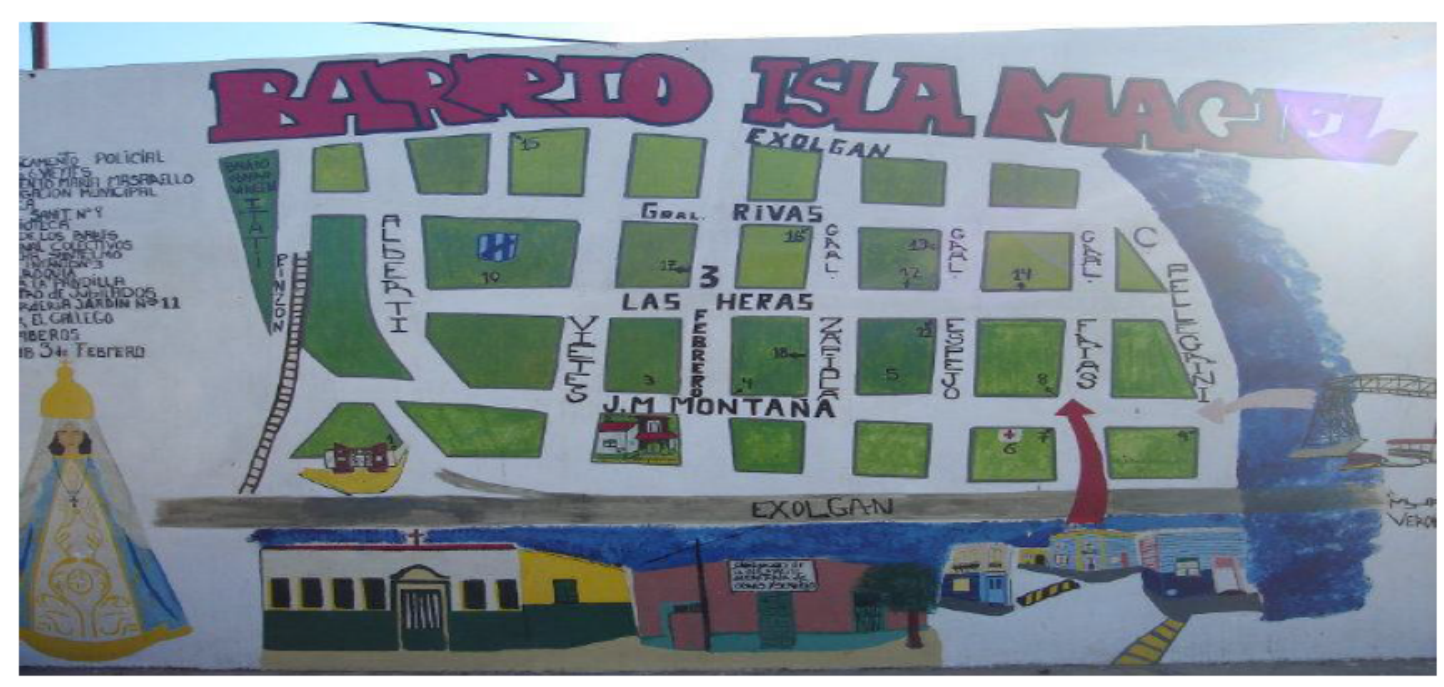


entubado) y las vías del tren, una vecina expresa: "Acá la villa del Fondo necesita que se arregle un poco, que se hagan algunas casitas, dúplex, algo mejor". En el mismo sentido Kevin, un joven de 14 años, ilustra la importancia que tiene la vivienda: "Me gustaría que todos tengan su casa bien, como tiene que ser (...) En el futuro me gustaría que (el barrio) sea igual que ahora, pero que se mejoren las viviendas".

También aparecen diferencias interpretativas entre ambos grupos de vecinos (los del barrio de La Boca y de la Isla Maciel) con relación a los habitantes de esos sub-barrios marginalizados. Mientras que para los vecinos de La Boca, estos habitantes constituyen claramente unos otros, más o menos amigables, para los de Isla Maciel están dentro del nosotros: "... yo por ejemplo al barrio Chino no iría nunca (dice una vecina Boquense) Un día fui a llevar un ramo de flores por allá lejos y me dije este es el barrio chino, y había unas caras que no me gustaban nada", "Dicen que ahí te hacen pagar peaje", dice otro.

Pero en la Isla Maciel, la movilidad interna es una características físico espacial que leída en términos del espacio social muestra la inestabilidad socioeconómica de la mayor

Como vemos, la entrada principal es desde La Boca, por el puente, desde dónde se abre la avenida principal, Montaña. Desde la entrada y hasta la calle Vieytes, se ubica la zona denominada el "Frente", que mantiene el trazado municipal en damero con manzanas y lotes "standard", el "Frente" es la zona mejor cotizada de la Isla. A partir de la calle Vieytes, alrededor de las vías del Ferrocarril y detrás de la cancha de San Telmo se extiende el "Fondo". Ésta es la zona más desfavorecida, allí el trazado de calles ha desaparecido y en su lugar se ve la tradicional disposición de pasillos angostos que se repite en muchas villas y asentamientos. Sobre la ribera del Riachuelo y hacia el oeste (a lo largo de lo que en la pintada ocupa el nombre del barrio) se denomina la "Playa" en alusión tanto a la costa del Riachuelo como a los terrenos que dan al margen Oeste sobre el que hasta hace pocos años se extendía el Arroyo Maciel, hoy entubado. 
parte de los vecinos, su poca capacidad -por causas externas ligadas al proceso de destitución del que son objeto- de previsión y proyección del propio hábitat.

Por eso, A diferencia de lo que ocurre en otros territorios con características similares -como por ejemplo Villa Inflamable (analizada por Auyero y Swistun, 2008), Villa Cartón (cuyo conflicto se hizo público a partir del incendio de 2007) o Villa Lugano (especialmente en los terrenos linderos al Parque Indoamericano, que sufre episodios recurrentes de violencia, los más salientes en 2010 y 2014)-; en Maciel no hay enfrentamientos entre los vecinos de los distintos barrios internos, al menos entre los adultos.

Esto se vincula con la gran movilidad interna de los habitantes del barrio: casi todos los entrevistados se mudaron una o varias veces dentro del territorio y habitaron alternativamente distintas zonas. Aunque los motivos de las mudanzas son muchas veces personales: "me casé", "me junté" o "me separé", la razón determinante es de índole económico-territorial. Así, cuando aparecen posibilidades de acceder a una casa mejor cerca del Frente o de ser adjudicatario de una vivienda en algún nuevo complejo de viviendas sociales, la familia se muda: "Nos mudamos porque no nos gustaba la casa, cuando llovía nos entraba el agua. Por esos nos fuimos para unas casas mejores" dice Julián de 11 años; "Me mudé como tres veces: vivía en el Fondo en un pasillo, después vinimos para el Frente y ahora estamos acá en la avenida. Me fue bien, ¿no?" concluye un vecino entre risas. Por el contrario, cuando las cosas van mal y hay que vender la casa, no se puede pagar más el alquiler, se incendia el conventillo o las condiciones edilicias de algún viejo departamento 
se tornan insostenibles, la familia vuelve al Fondo: "Mi marido quedó sin trabajo y nos tuvimos que venir para acá (para el Fondo). Nos levantamos una casilla atrás de lo de mi viejo y acá estamos por ahora"; "Me vine porque se me quemó la casa".

Volviendo a las categorías de análisis, mientras los vecinos de Isla Maciel destacan los problemas de vivienda para referirse al espacio tópico y sus dificultades de habitación, al caracterizar lo tópico los vecinos de La Boca refieren al espacio público y se extienden sobre la necesidad de ampliar o mejorar este aspecto: "Me gustaría que la ciudad sea más pública. Y los (espacios públicos) que hay, hay que mejorarlos, porque hay un déficit de inversión a nivel cultural muy grande en la ciudad en general. Más acá lo que es la Rivera Sur de Capital Federal, se nota mucho la diferencia comparado a Recoleta o Palermo", "... ahora con el nuevo temita este del Distrito de las Artes nos estamos moviendo bastante por la cuestión de que todo sea más público. Que todo tenga más acceso y demás. Por lo menos se trabaja bastante en La Boca. Diferentes agrupaciones trabajan mucho con esa problemática".

Un vecino de La Boca, de 56 años, destaca la importancia integradora del espacio público a partir del relato de lo que ocurre en un potrero convertido en canchita de fútbol por los vecinos: "Si no existiera un playón para jugar a la pelota, gratuito, la gente del barrio no tendría un lugar gratuito para hacer algún deporte, eso es importantísimo (...) los muchachos de Los Príncipes de La Boca (murga barrial) lo mantienen, lo cuidan para todos. Y tenés que ver cómo los turistas juegan a la pelota acá y se interrelacionan con los pibes. Entonces todo lo que sume a la actividad social está bien, hace bien". "Acá hay muchas plazas, pero 
hay que mejorarlas y mantenerlas para que pueda ir la familia", dice una mujer de 49 años, "hay una banda de plazas en La Boca pero están medio descuidadas" dice un joven de 21 años, y una señora mayor especifica: "A mí me gustaría que el Parque Lezama estuviera mejor, como cuando yo lo conocí".

Es decir, en el análisis de los entrevistados sobre las debilidades de sus espacios tópicos, encontramos diferencias entre los vecinos de Isla Maciel y los de La Boca que evidencian sus posiciones relativas respecto a los procesos de destitución social: Mientras los primeros habitan un territorio más castigado, la primera necesidad que aparece (y por lo tanto el primer derecho que debe ser garantizado) es la vivienda; pero en el caso de los vecinos boquenses las necesidades van más allá y señalan la importancia de los espacios públicos como lugares de integración e inclusión social. Esto se vincula con lo que señalamos unas páginas atrás sobre los cambios de la agenda de los sectores populares a partir de la reactivación del crecimiento económico, en comparación con lo que ocurría en década del 90 en la que la destrucción total de las fuentes de trabajo (formales e informales) desplazó el reclamo por tierra y vivienda a un lugar contextual-.

Con respecto a las narrativas que describen el espacio utópico -aunque con algunas diferencias entre ambos grupos de vecinos, que intentaremos explicar a continuación, la mayor parte de los entrevistados resalta el amor por su barrio poniendo de relieve la identidad territorial como eje estructurante de la utopía. 
Al ser consultados sobre qué lugar elegirían para vivir, si pudieran mudarse a cualquier barrio del AMBA, aparecen respuestas de este tipo: "A mí me parece que La Boca es uno de los mejores (barrios), será porque vivo acá...", "(me gusta) Caminito, por la historia, ¿viste? Uno viene acá y se transporta: te transportás al barrio donde creciste. La gente te saluda y no te conoce", "Me gusta este barrio (La Boca), todas las zonas de este barrio. No hay zona que no me guste porque nací aquí...", "Las zonas que más me gustan son la Vuelta de Rocha y el barrio Chino, pero de mi barrio me gusta todo".

Algunas de las personas entrevistadas en el barrio de La Boca, viven o vivieron en barrios linderos como Barracas y San Telmo y, en el mismo sentido, identifican el barrio en el que nacieron como el lugar en el que les gustaría vivir: "A mí me gusta San Telmo. Nací en ese barrio y me gusta todo", como explica con sencillez un hombre de 51 años que se autodefine como persona "en situación de calle", vecino circunstancial de La Boca (ya que vive transitoriamente en un hotel del Gobierno de la Ciudad): "Lo que más me gusta de la Ciudad es la esquina de San Juan y Boedo, porque ahí vivía mi papá y ahí viví de chiquito".

Así el espacio propio, mediado por la experiencia, se vuelve también utópico frente a la posibilidad de la identificación de las trayectorias de vida, las costumbres, etc. con un territorio determinado. Al profundizar en esta línea aparecen especificaciones que vinculan el espacio utópico no sólo a lo conocido, sino también con el sentido de pertenencia a una 
comunidad determinada ${ }^{25}$ : "(si pudiera elegir cualquier lugar) me mudaría a Barracas, donde nací, porque es muy barrio. Todavía podés saludar a la gente en la calle, salir a la vereda a tomar mate, esas cosas uno las valora mucho".

Para los vecinos de la Isla Maciel (como se desarrolla en el capítulo II) también la identidad territorial es un elemento central a la hora de definir el territorio utópico, con la diferencia de que en este caso al indagar la relación hábitat / futuro aparece una asociación simbólica entre el progreso personal y la posibilidad de mudarse a otro barrio. Es decir, la apropiación identitaria con el barrio entra en contradicción con la extrema estigmatización que pesa sobre él y la experiencia de muchos vecinos que han sido sistemáticamente discriminados por vivir allí: "A mí me gusta la Isla, el problema es el fantasma que ya le hicieron al barrio".

Así, la identidad territorial y la pertenencia comunitaria de los habitantes de barrios estigmatizados se ven -en palabras de Goffman- deterioradas. Por lo que un proceso de urbanización exitoso es el que logra garantizar el arraigo de la comunidad al territorio, reparando no sólo el deterioro de las condiciones habitacionales y ambientales sino también las identitarias.

\footnotetext{
${ }^{25}$ Para Gilberto Giménez, la pertenencia a un grupo es un criterio básico de "distinguibilidad" de los sujetos y, a la vez, su carácter relacional es el que hace posible la formación de identidades colectivas (Giménez, 2000).
} 


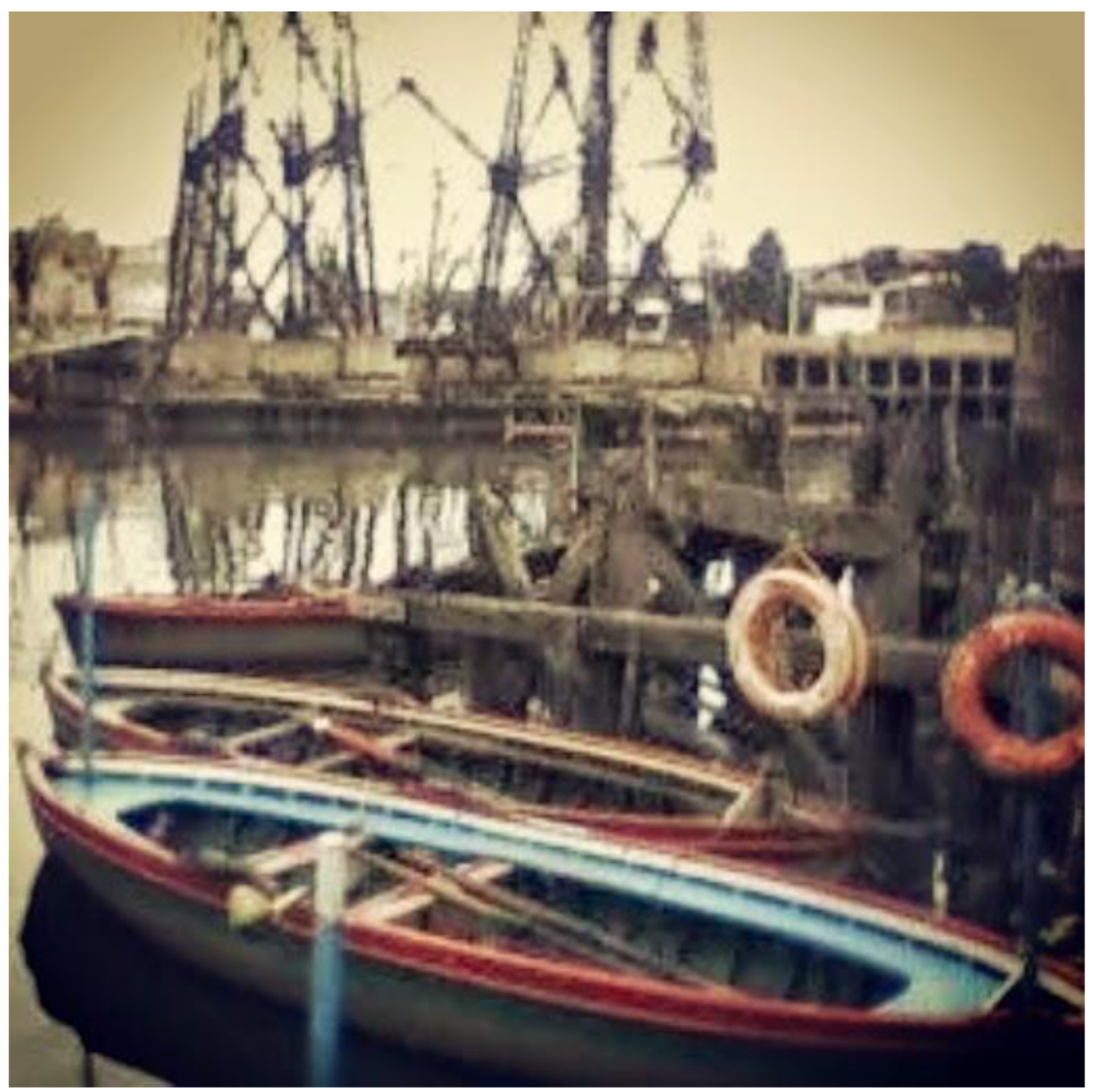




\section{Conclusiones}

El objetivo general de esta tesis fue analizar los procesos de exclusión y estigmatización territorial con el fin de producir aportes a las políticas de urbanización de barrios marginalizados en el AMBA. Este enunciado podría pensarse en dos partes, una de orden cognitivo -que implicó el estudio y la conceptualización de esos procesos en los barrios de La Boca e Isla Maciel- y otra de índole procedimental -que supone traducir en líneas de acción los resultados del análisis-. Sobre esto último versa este capítulo.

La aplicación de la investigación científica a la planificación de políticas sociales no es una práctica habitual, pero es necesario decir que no sólo las tesis doctorales sino que gran parte de la investigación producida desde las ciencias sociales sobre hábitat popular y pobreza urbana -incluida mucha de la bibliografía específica revisada en esta tesis- fue producida en el contexto de fines del siglo pasado- con Estados cómplices de los poderes concentrados internacionales, garantes de las desigualdades locales y funcionales al neocapitalismo salvaje- .

Así, sobre finales de los 90 y principios de este siglo, la investigación social puso el foco en las potencialidades de los movimientos sociales, alternativos y/o contra-hegemónicos, por un lado, y en la crítica a la intervención estatal, por el otro. En ese sentido, abundan las 
descripciones y las denuncias sobre políticas deficientes, corruptas o erradas. En esta tesis, sin embargó, se entendió que gran parte de esas nociones siguen ancladas a claves interpretativas de otro momento histórico, por lo que, aunque es ineludible revisarla para conformar un estado de la cuestión, su reproducción acrítica en el contexto actual devendría en un cúmulo de respuestas a preguntas que ya dejamos de formularnos hace tiempo. El devenir histórico, social y político generó una demanda de conocimiento más compleja, que trascienda la reflexión crítica y comience a pensar los modos de hacer, de producir, de planificar y de gestionar.

La emergencia de nuevos gobiernos populares en América Latina obliga a repensar tanto esas claves conceptuales, como el sentido mismo de la producción de conocimiento social. En esa dirección, de producir colectivamente conocimiento sobre los problemas de los pueblos para intervenir en la realidad y transformarla, vinimos trabajando en el Instituto de Investigaciones en Comunicación de la Facultad de Periodismo y Comunicación Social, en el que participo desde su creación. Así, el proceso de enseñanza / aprendizaje que constituyó la realización de esta tesis en el marco del IICom se alojó desde el principio en la posición epistemológico-política de producir conocimiento para acompañar las políticas sociales diseñadas y gestionadas por parte de un Estado popular e inclusivo. En palabras de Boaventura de Souza Santos, se trata de pensar al Estado ya no como un enemigo de los movimientos sociales sino como un "novísimo movimiento social" que, junto a la comunidad, puede garantizar "la sostenibilidad de las interdependencias no mercantiles en ausencia de las 
cuales la vida en sociedad se convierte en una forma de fascismo societal" (de Souza Santos, 2005).

En esta investigación se enfocó un aspecto de la política social (la urbanización de villas, asentamientos y barrios marginalizados del AMBA) caracterizándola como una relación de comunicación entre el Estado y el pueblo. En este marco conceptual y como se desarrolló a lo largo de la tesis, se asumió la hipótesis de que -a diferencia de lo que ocurría bajo el Estado neoliberal- el Estado popular viabiliza las oportunidades para el desarrollo de una política social integral, con mayores grados de organización e interrelación entre sus componentes.

Por eso, más que por mera afinidad ideológica, porque esta investigación intentó hablar y ser hablada por la política y por el pueblo, es que las conclusiones a las que nos permiten arribar sus resultados se plantean a partir de tres ejes de acción que atraviesan el conjunto de la política social argentina $y$ a la vez reactualizan la memoria del Estado popular: independencia económica, soberanía política y justicia social 26. Así, a través de estos tres ejes, se ponen en diálogo los antecedentes teóricos, históricos y estadísticos, el análisis documental, las entrevistas y el trabajo etnográfico con los procesos e iniciativas vigentes

\footnotetext{
${ }^{26}$ Según el propio Ministerio de Desarrollo Social: "Esas tres banderas del movimiento peronista han expresado un horizonte que, si bien fue formulado desde una identidad política específica, expresan en perspectiva histórica y sobre todo en la actualidadla posibilidad de constituirse en los principios de acuerdo básico para un proyecto nacional y popular para toda la nación" (www.desarrollosocial.gov.ar, 20/02/2014).
} 
de política social para ensayar propuestas y nuevas líneas de acción con el objetivo de mejorar y potenciar las políticas de urbanización.

\section{Independencia económica}

Así como en diversos aspectos de la economía argentina se plantea un modelo que prioriza la producción de valor agregado, de igual manera en los territorios marginalizados se puede considerar prioritaria la puesta en valor en el marco de la urbanización. Poner en valor, no refiere únicamente al necesario respeto el arraigo barrial, las identidades comunitarias y la generación de puestos de trabajo, sino que implica también recuperar el patrimonio cultural y la memoria histórica -especialmente la memoria productiva- como forma de empoderar a la comunidad y fortalecer su autoestima: rescatar los saberes y logros históricos para actualizarlos como repertorios de la acción colectiva y valores positivos de la identidad comunitaria.

Como dijimos en el inicio de este capítulo, esta investigación tiene una perspectiva

política diferente a la que plantean otros autores más cercanos a la crítica de la 
intervención estatal. Por ejemplo, Rodríguez, Di Virgilio y otros, $2007^{27}$ señalan el hecho (negativo, a su criterio) de que las políticas de autoproducción nunca alcanzaron una escala masiva. Pero la crítica, válida hasta hace poco menos de una década hoy aparece descontextualizada: hubo un tiempo en el que se priorizó la autoconstrucción del hábitat y la creación de cooperativas de vivienda como modo de asegurar, a través de la obra pública, la subsistencia económica de la comunidad en proceso de urbanización. Efectivamente, las políticas de autoproducción del hábitat fueron experiencias valiosas para salir de la honda crisis de fin de siglo y a la vez sirvieron en muchos casos para generar cohesión comunitaria, reparando lazos sociales que habían sido desgarrados por las dictaduras primero y el neoliberalismo después. No obstante, se trata de una medida que es por definición paliativa: el trabajo en la construcción no necesariamente forma parte del proyecto de vida de todos los sujetos y familias con problemas habitacionales y, por otro lado, los planes de autoproducción tienen como objetivo finalizar en el corto o mediano plazo. Es decir, a la luz del crecimiento que tuvo Argentina en la última década, la autoproducción no puede funcionar como único modo de asegurar fuentes de trabajo e inversión.

Por el contrario, las iniciativas vinculadas a la puesta en valor de los territorios pueden constituir estrategias más eficientes a mediano y a largo plazo, ya que la perspectiva de recuperar la memoria cultural y productiva de los barrios posibilita a la comunidad la

27 "El programa (Techo y Trabajo) está dirigido para ejecutarse por empresas constructoras, con lo cual se favorece la tradicional relación entre dos actores: el sector de la industria de la construcción y el Estado (...) Finalmente, la participación de los sectores beneficiarios y de las organizaciones de la sociedad civil está ausente por completo" (Rodríguez, Di Virgilio y otros, 2007). 
reactivación de procesos productivos potencialmente sostenibles. Así, las políticas de puesta en valor permiten un punto de partida universalizado para la urbanización de villas y asentamientos en el AMBA y, a la vez, habilitan el diseño estrategias flexibles, según las particularidades y las diversas identidades comunitarias.

En el caso de los territorios estudiados, la memoria productiva remite al trabajo asalariado industrial y hubo coincidencias entre los vecinos de La Boca, Barracas e Isla Maciel en relacionar el trabajo en puertos, fábricas y frigoríficos con los relatos de momentos felices para las familias y de progreso barrial (Vidarte Asorey, 2010).

Para los vecinos de La Boca, se suma el importante desarrollo cultural que históricamente caracterizó a esos arrabales y que hoy se resignifica a partir de los museos, espacios culturales y espectáculos callejeros que son masivamente visitados por vecinos y turistas del país y el extranjero. La memoria cultural del barrio sigue generando fuentes de trabajo: "(Lo que más me gusta es) Caminito, por la historia, ¿viste?", "En el futuro me gustaría que estemos mejor, que venga para acá un turismo mejor para que haya más trabajo". También la Isla Maciel, primer barrio del partido de Avellanada, -fue fundada en 1887 pero de que existe desde 1770 (Vidarte Asorey, 2009)- tiene un gran patrimonio cultural, hoy olvidado, que sería necesario revalorizar.

La necesidad de poner en valor la memoria cultural y productiva apareció en las entrevistas de forma bastante clara: "Barracas, por ejemplo. Esa zona era un emporio pero 
lamentablemente cerraron muchas fábricas, el puente no funciona más", "Muchos trabajaban en el puerto y muchos en el astillero naval, entonces había mucho movimiento", "... parece mentira pero había industria acá (en la Isla Maciel), y carnicerías, carpinterías, astilleros. Es increíble", "Fui portuario, el único trabajo que tuve", "Por donde vivía yo se construían carcasas navales"; "Acá tenían todo, talleres, astilleros, era muy movido el tema del trabajo. El astillero Menghi, tenía 3400 personas que trabajaban en tres turnos; en el Alianza, que trabajaba yo, éramos 1800; en Sadín, 2000 personas, y así. Y también los talleres que eran más chicos pero había un montón".

En el sentido de reactivar la actividad productiva industrial es apropiado señalar la relevancia de iniciativas -llevadas adelante de forma coordinada entre la Nación y los municipios- como la creación de parques industriales en aquellos territorios que otrora funcionaron como polos productivos de la industria nacional. Actualmente, hay aproximadamente 400 parques industriales en todo el país y más de 300 de ellos fueron creados en la última década en el marco de la política reindustrializadora propia del modelo de "crecimiento con inclusión social". Específicamente en la zona estudiada en esta tesis, debemos resaltar la reciente inauguración de uno de ellos en el partido de Avellaneda.

Otro aspecto importante en términos de sustentabilidad económica de la comunidad es el transporte, ya que vincula los territorios con el campo productivo de la ciudad (cuyo centro neurálgico está en el casco urbano). En esa dirección también se han realizado grandes 
avances en materia ferroviaria que impactan directamente en la zona sur de la CABA y el primer cordón del Conurbano sur. Por otra parte, si bien muchos colectivos transitan por el barrio de La Boca, son muy pocos los que llegan hasta la Isla Maciel (las líneas 271 y 570 , esta última volvió a funcionar luego de décadas y conecta la Isla con Villa Tranquila, Avellaneda centro y Piñeyro). El acceso al transporte constituye una herramienta básica para garantizar el derecho a la ciudad; un ejemplo claro es el que se desarrolla en el Capítulo I cuando se narra la odisea que constituyó para Cacho (uno de los informantes en profundidad) movilizarse desde la Isla Maciel hasta Chacarita en busca de un puesto de trabajo.

Desde una perspectiva relacional, que articule política social y económica, estas iniciativas de gran envergadura (como la creación de un parque industrial) pueden robustecerse con acciones complementarias, como por ejemplo medidas de discriminación positiva que incentiven a las empresas a tomar prioritariamente personal residente en estos barrios y aumentar la subvención al transporte de los vecinos de territorios en proceso de urbanización y/o que han sido recientemente urbanizados -del mismo modo que se hizo al lanzar el PROGRESAR ${ }^{28}$, cuando se acompañó de un subsidio implementado a través de la tarjeta SUBE ${ }^{29}$.

\footnotetext{
${ }^{28}$ El Programa de Respaldo a Estudiantes Argentinos, PROGRESAR, creado el 23/1/2014 por decreto del PEN N ${ }^{\circ} 842014$ consiste en una prestación (una suma de dinero mensual no contributiva) destinada a los jóvenes de entre dieciocho (18) y veinticuatro (24) años de edad inclusive, que pertenecen a grupos vulnerables -cuyo ingreso o el del grupo familiar no superen el salario mínimo, vital y móvil-, para iniciar o completar su formación. El monto inicial de la prestación se fijó en $\$ 600$.
} 
Las acciones de este tipo, aunque por sí solas sean meros paliativos, incorporadas en el diseño como partes de una totalidad relacional y compleja, pueden permitir mantener incluidos a los sectores vulnerables, mientras se avanza en la concreción de metas intermedias y objetivos de largo plazo.

\section{Soberanía política:}

El concepto de soberanía política refiere a la capacidad de los pueblos de autodeterminarse. Es decir que una comunidad es más soberana, cuanto mayor es su posibilidad de definir las expectativas de futuro y de establecer la dirección política que quiere seguir para alcanzarlo. Retomamos esta noción para pensar la problemática habitacional; en este caso, como en tantos otros, los intentos de colonialismo no provienen sólo de naciones extranjeras sino especialmente de grandes corporaciones nacionales o transnacionales, por lo que la puja central se puede sintetizar en la mentada antinomia Estado vs. Mercado.

Se trata de dos modelos económicos y políticos en disputa: en uno, hay un estado popular que defiende la soberanía del pueblo e interviene para cuidar sus intereses; en otro, un

${ }^{29}$ SUBE: Sistema Único de Boleto Electrónico, es un servicio para abonar con una sola tarjeta los viajes en colectivos, trenes y subtes en la región metropolitana de Buenos Aires. 
estado neoliberal cuya función se limita a administrar la desigualdad. Se trata, a la vez, de la lucha entre dos proyectos de nación y dos paradigmas culturales de producción, circulación y uso del territorio urbano.

Ya analizamos cómo en el AMBA, en términos urbanísticos, desde mediados del siglo pasado, existieron períodos de aperturismo salvaje al Mercado -especialmente durante las últimas dictaduras militares y luego en la década del 90- que contaron con la anuencia de Estados cómplices; y también cómo los gobiernos populares que intentaron una mayor intervención encontraron sistemáticas trabas para la gestión de políticas habitacionales inclusivas.

Así, una política social emancipadora, que sólo puede ser posible desde el Estado popular, debe desplegarse en dos direcciones: La primera es la inclusión masiva de los sectores populares -subalternizados por el neocapitalismo global y sus socios locales- a través la ampliación de derechos (humanos, civiles y sociales), como el derecho a la ciudad y al hábitat y la vivienda dignos. La segunda, es el empoderamiento popular a través de garantizar la participación del pueblo, dotarlo de agencia y legitimar su voz en los espacios de lucha, debate y decisión.

Durante los últimos años se avanzó significativamente en la inclusión de sectores populares y la ampliación de derechos. Así, se marcó una tendencia -que aún es incipiente- al abordaje relacional de la política social a partir de la coordinación y articulación múltiple 
en los procesos de diseño, planificación y gestión. Esta tendencia relacional reconfigura el horizonte de expectativas para investigadores, técnicos y políticos.

Enfocando directamente en los habitantes de territorios marginalizados y repasando sólo algunas iniciativas en este sentido, que aún no hemos mencionado, podemos señalar por ejemplo el plan piloto que se puso en marcha durante 60 días en el año 2012, en el que siete carteras

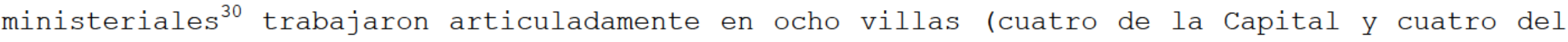
Conurbano) coordinadas por el Ministerio de Desarrollo Social con excelentes resultados. A nivel nacional, es muy destacable el trabajo del Consejo Nacional de Coordinación de Políticas Sociales -integrado por Ministerios, Secretarías y organizaciones de la sociedad civil, y presidido por el Ministerio de Desarrollo Social- especialmente a partir de los Centros Integradores Comunitarios, CIC, que vinculan a la comunidad con políticas sociales nacionales, provinciales y municipales.

En las zonas con mayor concentración de villas y asentamientos del AMBA y en el tema de seguridad, son relevantes las experiencias de los operativos Centinela, Acceso a Buenos Aires y Unidad Cinturón Sur -que reasignaron personal de Gendarmería Nacional para trabajar coordinadamente con la Policía Federal y/o la Policía Bonaerense-. Estos operativos

\footnotetext{
${ }^{30}$ Las carteras que intervinieron son Desarrollo Social, Seguridad, Defensa, Educación, Salud, Interior y Trabajo.
} 
evidenciaron que la presencia de Prefectura y Gendarmería es percibida positivamente en los territorios, sobre todo con relación a la presencia de las policías Federal y Bonaerense ${ }^{31}$.

En un sentido similar, recientemente se implementó la presencia del Ejército Nacional en territorios que están en proceso de urbanización. La experiencia, que se coordinó con organizaciones sociales y políticas con presencia territorial, comenzó en Florencio Varela y luego se extendió a La Carbonilla (en el barrio porteño de Paternal). En este caso, los soldados que pertenecen al Batallón 601 de Ingenieros desarrollan tareas ligadas a infraestructura barrial y tienen prohibido intervenir en cuestiones de seguridad interior. Así, la articulación con el Ejército es doblemente positiva en tanto no se socaba el espíritu de la institución ni se ponen en riesgo los derechos humanos de los habitantes.

El tipo de políticas sociales articuladas que venimos mencionando han dado muestras de ser eficientes para gestionar respuestas superadoras ante problemáticas complejas, lo que evidencia la importancia de profundizar en esta dirección.

\footnotetext{
${ }^{31}$ Para profundizar sobre los cambios positivos que estas políticas de seguridad mostraron no sólo en los territorios sino también al interior de las fuerzas, puede leerse: Barrera, N., Bianciotto, L. y otros. (2012) "Seguridad para Todos. Territorios y Policíamientos".Grupo de Estudio sobre Policías y Fuerzas de Seguridad CAS-IDES. Revista Voces del Fénix.
} 
Desde el punto de vista del aumento de la participación ciudadana en las políticas sociales, el ejemplo paradigmático es la implementación del presupuesto participativo (PP) que, luego de algunas pruebas piloto, se consolidó en 2009 con la constitución de la Red Argentina de Presupuestos Participativos, integrada por la Secretaría de Relaciones Parlamentarias de la Jefatura de Gabinete de Ministros de la Nación, la Secretaría de Asuntos Municipales del Ministerio de Interior, los Municipios que desarrollan la herramienta y Universidades con interés en la materia.

El peso promedio del PP es del 2,5\% de los respectivos gastos municipales, con valores que algunos casos no alcanzan el 1\% y en otros superan el 5\%. En cuanto a la participación de los ciudadanos "resulta necesario extremar las precauciones a la hora de sacar conclusiones (...) principalmente por la forma en que cada comuna desarrolla el proceso de PP y por ende de cómo define y cuantifica la participación popular" (López Acoto, A. Martínez, C y Addaro, C. 2012). Pero aunque el PP no alcance la escala suficiente para dar cuenta de por sí de su eficacia, resulta un ejemplo ilustrativo para analizar el diseño y los modos de gestión de las políticas participativas. En general, los investigadores que analizan la implementación del PP coinciden en señalar ciertos puntos que se evidencian como falencias u oportunidades para mejorar, especialmente con relación a la comunicación y la información, por un lado, y a la pequeñísima escala de decisión, por el otro (Arocena, J., 1999; Iazzeta, O., 2000; Jouve, B., 2004; López Acoto, A. Martínez, C y Addaro, C. 2012). 
La referencia concreta a los problemas de comunicación abarca tanto la fluidez del diálogo entre la comunidad y las distintas áreas del Estado -que se señala como heterogénea, según la implementación en cada distrito-, como el acceso de los vecinos a fuentes de información confiable sobre los temas de interés. En este punto, una acción posible para mejorar el proceso de comunicación y a la vez asegurar el acceso a la información, es incorporar a las mesas de diálogo actores que garanticen la calidad de la información proporcionada a las comunidades ${ }^{32}$, tanto para el caso de las estadísticas (INDEC y Universidades Nacionales) como del material tomado de los medios masivos (Defensoría del Público $\left.{ }^{33}\right)$.

Con respecto a los problemas de escala del PP, los mismos trabajos de investigación entienden que, más allá del pequeño porcentaje que constituye el PP dentro del presupuesto total de un municipio, el mayor inconveniente es de índole cualitativa ya que muchos de los

\footnotetext{
${ }^{32}$ La iniciativa puede trasladarse a otras políticas participativas que utilicen la metodología de mesas de diálogo con la comunidad, ya que implica garantizar el acceso a la comunicación y a la información; es decir, garantiza un derecho humano y democratiza el mapa de actores.

${ }^{33}$ La Defensoría del Público de Servicios de Comunicación Audiovisual se crea a partir de la Ley 26.522 de Servicios de Comunicación Audiovisual -que reconoce que los medios de comunicación son de interés público, que la información es un derecho y que las trabajadoras y trabajadores de los medios tienen responsabilidad socialcomo un espacio para que los oyentes y televidentes puedan presentar sus consultas, reclamos y denuncias, como estrategia para ampliar el derecho a la comunicación, a dar y recibir información, ideas y opiniones, a buscarlas y difundirlas.
} 
problemas que aquejan la vida cotidiana de los vecinos son complejos, multicausales y no pueden abordarse únicamente desde el ámbito distrital.

Entonces, situados en una tendencia relacional de las políticas sociales, la dimensión municipal resulta muchas veces reducida, tanto para la participación y la intervención de la comunidad en la agenda social y política, como en la capacidad de garantizar derechos y en la posibilidad establecer diagnósticos integrales. Es decir, más allá de la escala cuantitativa, para profundizar en la ampliación de soberanía en los territorios marginalizados es necesario interpretar cualitativamente la problemática del hábitat popular metropolitano -y específicamente la urbanización de villas y asentamientos- para poder diseñar políticas que abarquen la complejidad del AMBA.

Hay niveles de organización que no se alcanzan desde el ámbito distrital ya que la producción, la circulación y el uso del territorio urbano en el AMBA conciernen tanto a la CABA como a la Provincia de Buenos Aires y a los respectivos municipios del Conurbano, a la vez que están inmersas en un modelo de país determinado que se define desde la órbita nacional. De acuerdo a esto, una propuesta superadora es la creación de un área multijurisdiccional: Una Autoridad Metropolitana, a la manera del modelo ACUMAR ${ }^{34}$, en la que,

\footnotetext{
${ }^{34}$ La Autoridad de la Cuenca Matanza - Riachuelo, se crea en 2008, a raíz de un fallo judicial que exhorta a resolver la problemática ambiental de la zona que había sido abandonada por las autoridades durante años. Así, se conformó una autoridad multijurisdiccional conformada por el Estado Nacional, el de la Provincia de Buenos Aires, el de la Ciudad Autónoma de Buenos Aires, 44 empresas que operan en la cuenca y, posteriormente, se amplió hacia los 14 municipios de la Provincia de
} 
sin perder su autonomía, los distintos niveles estatales y actores comunitarios, se encarguen conjuntamente del diseño, la planificación y la gestión de políticas habitacionales y de urbanización territorial, en sintonía y de forma sinérgica con las políticas nacionales de producción del suelo urbano.

A priori, esta propuesta puede resultar ambiciosa: ya hemos señalado la imposibilidad de desarrollar este tipo de iniciativas fuera del marco de oportunidad política y sustentabilidad económica. No obstante, -como entendemos que están dadas las condiciones políticas- la sustentabilidad económica se puede lograr a partir de reorganizar y optimizar recursos tanto humanos (con relación a la estructura burocrática) como materiales (para minimizar la inversión presupuestaria). Por mencionar sólo algunos ejemplos, en la Provincia de Buenos Aires, la demorada implementación de la Ley de Acceso Justo al Hábitat, permitirá aumentar los ingresos fiscales por medio de las multas a la vivienda ociosa y el impuesto a los desarrollos inmobiliarios en grandes superficies. La CABA, por su parte, tiene altísimos índices de sub-ejecución presupuestaria especialmente en el área social: en el caso del presupuesto destinado a urbanización de villas y asentamientos, entre 2008 y 2013 se utilizó sólo el $46 \%^{35}$.

Buenos Aires por los que se extiende la cuenca Matanza -Riachuelo, la Defensoría del Pueblo de la Nación y un grupo de ONG que conformaron un cuerpo colegiado con el fin de supervisar la aplicación del Plan de Saneamiento.

${ }^{35}$ Pertot, W. "Sin plata para las villas" Página 12, 1/06/2014. 


\section{Justicia social:}

En el capítulo anterior, dijimos que la Inseguridad como fenómeno social se compone tanto de la percepción colectiva que se tiene de ella como de los hechos delictivos reales, entonces volvamos por un momento a revisar la situación del delito violento en los territorios marginalizados ${ }^{36}$.

La tasa de homicidios dolosos en el AMBA (6,93 por cada 100.000) es de las más bajas de América Latina pero, por otro lado, aparecen nuevas lecturas cuando analizamos los datos en clave territorial: en la Ciudad de Buenos Aires, el índice de homicidios dolosos cada 100.000 habitantes es 5,46 -de acuerdo a esto, la CABA es la segunda ciudad más segura de América, superada sólo por Toronto (Rodríguez, 2010)- mientras que en el Conurbano alcanza el 7,66. En este último caso cabe aclarar que el índice engloba al total de la Provincia, incluido el

\footnotetext{
${ }^{36}$ Las cifras más recientes que han sido trabajadas en forma comparativa por países corresponden al año 2008. En ellas, se advierte que en Argentina hay 5,8 homicidios cada cien mil habitantes, lo que ubica a nuestro país en el cuarto lugar como país más seguro del continente. Sólo son más bajos los porcentuales de Chile (1,6 homicidios cada cien mil habitantes), Canadá $(1,83)$ y Estados Unidos ( 5,4 cada cien mil habitantes), mientras que la estadística negativa es encabezada por Honduras (57,9), Venezuela (52) y Guatemala (49 homicidios dolosos cada cien mil habitantes). Rodríguez, C. "Las callecitas de Buenos Aires tienen ese no sé qué...”. Página 12, 19/09/10.
} 
Conurbano Bonaerense; aunque en el Informe Anual 2012 sobre Estadística criminal de la Provincia de Buenos Aires, se especifica que en la tasa total (7,66), el 59\% de los hechos analizados corresponde a crímenes cometidos en el Conurbano, mientras que el 41\% restante ocurre en el resto del territorio provincial ${ }^{37}$.

En el mismo sentido, al desagregar por comunas los índices de la CABA, vemos que el 73응 de los casos ocurre en la zona sur de la Ciudad. Es decir, paralelamente a la percepción de inseguridad que hay en ellos, los barrios más pobres del AMBA son los que sufren más violencia cotidiana (sobre todo violencia institucional e intrafamiliar).

Esto surge también de los relatos de los entrevistados: "hubo una época en la que estuvimos mucho mejor y ahora con el tema de la gestión de Macri hemos notado muchas problemáticas (...) desalojos, represión por parte de la Metropolitana, seguimientos, persecución a diferentes individuos y colectivos que están acá dentro del barrio".

Las características que adquieren estos altos niveles de violencia cotidiana se desprenden de algunos datos cualitativos. Por ejemplo, según el Instituto de Investigación en HD de la CSJN, el tipo de homicidio doloso más habitual es el que ocurre en situación de riña, enfrentamiento o ajuste de cuentas entre conocidos -casi 40\% en 2011 más $11 \%$ de

\footnotetext{
${ }^{37}$ De acuerdo a estos datos (incluidos los del Informe sobre Estadística Criminal que realiza la propia Provincia), llama la atención la extemporánea declaración de Emergencia en Seguridad, decretada en abril pasado por el Ejecutivo Provincial, que parece responder, más que a necesidades concretas de los bonaerenses, a requerimientos propios del escenario mediático preelectoral.
} 
violencia intrafamiliar (IHD, CSJN)-, se observa también que la mayoría tienen lugar en los fines de semana (en especial en los largos), casi siempre de noche o madrugada y en el 60 \% de los casos en la calle.

Las situaciones más violentas se dan justamente entre familiares, amigos y vecinos, en los momentos que suelen dedicarse al ocio, el esparcimiento y la vida social y familiar. Lo que denota la pertinencia de contener especialmente a la comunidad en ese aspecto, cubriendo no sólo las necesidades habitacionales urgentes (vivienda, servicios públicos e infraestructura) sino también viabilizando y promoviendo la participación política, cultural, artística y recreativa de los habitantes de los territorios en proceso de urbanización.

En capítulos anteriores, se precisaron los alcances de la violencia institucional en los barrios marginalizados que van en el mismo sentido que muestra la estadística criminal. Como ejemplo, vale el dato que señalábamos en el capítulo I: menos del 1\% de los menores que participa en hechos delictivos comete homicidios dolosos. Mmientras que -según se expresa en el Informe Anual 2012 sobre Estadística criminal de la Provincia de Buenos Aires-, en los casos de homicidio doloso cometidos en los ámbitos intrafamiliar e intrainstitucional, el 54\% 
de las víctimas tienen entre 0 y 15 años ${ }^{38}$. Como señala en primera persona un grafiti pintado por un grupo de jóvenes en la entrada de la villa La Cava: "no somos peligrosos, estamos en peligro"

Así, -a diferencia de la antinomia que señalamos para caracterizar la disputa principal en el eje conceptual independencia económica (Estado versus Mercado) en el que los modelos de estado en pugna son el popular y el neoliberal- en los territorios marginalizados los altos niveles de violencia cotidiana denotan la preeminencia de un estado gendarme residual. Por lo que la tensión en este eje se expresa más claramente en la oposición entre el estado popular y el estado gendarme o policía. El escenario como vimos, tiene alcances y característica que exceden no sólo el ámbito local sino también el nacional y puede ilustrarse con la famosa definición gramsciana de la crisis como el momento histórico en el que "lo viejo no termina de morir y lo nuevo no termina de nacer". A la postre, de cara a los sectores populares el Estado neoliberal se traduce casi exclusivamente en estado gendarme (o policial, para Wacquant); y aunque hace entre 10 y 15 años surge en América Latina (y específicamente en

\footnotetext{
${ }^{38}$ En el caso de los homicidios dolosos cometidos en la vía pública y otros ámbitos, se observa una distribución equitativa de las víctimas según las franja etarias 0 a 15 y 16 a 40. Estadística criminal de la Provincia de Buenos Aires _ Informe anual 2012.
} 
Argentina) un nuevo escenario protagonizado por estados populares, la justicia social sigue estando muy lejos de los territorios excluidos.

Por otra parte, la gestión territorial del estado popular en Argentina está mostrando una fortaleza en términos de política social: la flexibilidad-con relación a su creciente capacidad de gestión del conflicto-. No parte de un ideal preconcebido sino de los problemas de la realidad material, con sus complejidades y sus tensiones. Así, la planificación es muchas veces contemporánea a la gestión y va tomando forma con el tiempo, desde dentro del conflicto. Muestra de esto es la gran cantidad de iniciativas y líneas de acción que mencionamos a lo largo de la tesis. Estas acciones de política social son en general muy recientes, lo que las vuelve difíciles de diagnosticar de modo concluyente), sobre todo las que desarrollamos en este capítulo en los dos ejes anteriores (independencia económica y soberanía política).

Con relación al eje de la justicia social, también hay intervenciones del Estado a través de las herramientas institucionales de las que dispone para tratar de garantizar el acceso a la justicia de los sectores vulnerables y para regular los altos niveles de violencia cotidiana y violencia institucional en las villas y asentamientos del AMBA. Concretamente, desde el Ministerio de Justicia y Derechos Humanos (MJDDHH) se están llevando adelante acciones significativas en esta línea. 
En primer lugar en el año 2008, mediante el Decreto $N^{\circ}$ 1755/08, se crea en el MJDDHH la Dirección Nacional de Promoción y Fortalecimiento para el Acceso a la Justicia (dentro de la órbita de la Subsecretaría de Relaciones con el Poder Judicial, de la Secretaría de Justicia de la Nación). Esta Dirección se pone en funcionamiento desde su inicio con el objetivo de "fortalecer y ampliar las políticas de acceso a la justicia específicamente las destinadas a los sectores más vulnerables de la población (www.jus.gov.ar, 2014)". La Dirección implementó un programa de Centros de Acceso a la Justicia (CAJ), que son espacios en los que se brinda asesoramiento y orientación profesional a la comunidad. En los CAJ trabajan equipos interdisciplinarios (abogados, psicólogos, trabajadores sociales y mediadores comunitarios) que asesoran a los vecinos $y$, a la vez, coordinan acciones conjuntas con organismos nacionales, locales y programas sociales de alcance nacional. Hasta el momento, los CAJ están dando resultados muy auspiciosos, especialmente en cuánto a contención y asesoramiento a la comunidad.

En la misma dirección y dentro los territorios que nos ocupan, se lanzó recientemente el Programa de Agencias Territoriales de Acceso a la Justicia (ATAJO); que comenzó a funcionar con cuatro sedes: Villa 21-24 (Barracas), Villa 1-11-14 (Flores), Villa 31 (Retiro) y Barrio Mitre (Saavedra). Según afirma el Defensor Penal Juvenil Julián Axat, a cargo del programa: "el grave problema del acceso a la justicia ha llevado también a repensar el papel del Ministerio Público Fiscal, en especial en territorios con población vulnerable y de alta 
conflictividad" ${ }^{9}$. Axat sostiene que desde la Procuración General se busca alentar un nuevo modelo que piense a los fiscales como agentes de prevención y promoción de derecho y no sólo como acusadores, vinculados a las fuerzas punitivas. ATAJO aparece como una iniciativa interesante, aunque hasta ahora no queda clara la necesidad de replicar un modelo tan similar al de los CAJ desde otra dependencia en vez de potenciar su funcionamiento.

En general, aún cuando estos programas de acceso a la justicia -sobre todo ATAJO- están en una instancia inicial, a partir de la implementación de los mismos y de las palabras de los responsables políticos e institucionales, podemos concluir que el diagnóstico que se vino desarrollando en esta tesis coincide con la valoración de la situación por parte del gobierno nacional: las villas y asentamientos son los barrios de mayor conflictividad, tanto por los altos grados de violencia cotidiana como por la extrema vulnerabilidad de sus habitantes que obedece a diversos motivos y procesos, entre ellos, la privación del acceso a una justicia legítima e igualitaria.

En este sentido, el Secretario de Justicia de la Nación, Julián Alvarez explica (sobre estos programas) que "el acceso a la justicia es una política que surge de los hechos y que desde que se puso en marcha soluciona problemas concretos de los habitantes de los barrios más humildes" (Hauser, 2014). No obstante, aún cuando -como dijimos- las acciones llevadas adelante desde el año 2003 por el MJDDHH dan cuenta de un diagnóstico realista así como

\footnotetext{
${ }^{39}$ Hauser, I. (2014) "Acceso a la Justicia con fiscales villeros", Páginal2, 09/06/14.
} 
también del compromiso por lograr un sistema de justicia más inclusivo; también es cierto que éstas políticas no tuvieron el correlato necesario dentro del Poder Judicial. Como vimos, los programas e iniciativas que tienden a la ampliación de la Justicia dependen en todos los casos del Poder Ejecutivo ${ }^{40}$. Por lo que en este punto, con relación al eje justicia social, se frena todo avance hacia la tendencia relacional de las políticas sociales integradas que organicen, articulen y coordinen estratégicamente los distintos niveles, recursos y jurisdicciones del Estado. En este sentido se evidencia la deuda del Poder Judicial con su propia reforma a fin de propiciar una organización más inclusiva. Por último, y hasta tanto eso no ocurra, una propuesta posible es -así como lo hizo la CSJN para el caso de los homicidios dolosos- optimizar la tarea así como la inserción territorial de los CAJ para avanzar en la producción de conocimiento y la sistematización de datos sobre las características de los procesos de estigmatización y las problemáticas de violación de derechos y negación de justicia.

\footnotetext{
${ }^{40}$ Secretaría de Justicia de la Nación, Ministerio Público Fiscal y Ministerio Público de la Defensa.
} 


\section{Bibliografía Inicial}

AA. VV (2003) La criminalización de la protesta social. La Plata. Editorial Grupo La Grieta. Abba, A., Furlong, L., Susini, S. y Laborda, M. (2008)"Informe sobre nivel socio habitacional". Buenos Aires. Atlas Buenos Aires.

Acuña, C., Kessler G. y F. Repetto (2002) "Evolución de la política social argentina en la década de los noventa: cambios en su lógica, intencionalidad y en el proceso de hacer política social." Texas. Center of Latin American Social Policy. Universidad de Austin.

Alabarces, P. (2002) Fútbol y Patria: el fútbol y las narrativas de la Nación en la Argentina. Buenos Aires. Prometeo.

_ P.y Rodríguez, M. (2008) Resistencias y mediaciones. Buenos Aires. Paidós.

Alarcón, C. (2003) Cuando me muera quiero que me toquen cumbia, Vidas de pibes chorros. Buenos Aires, Norma.

Amin, S. (1973) El desarrollo desigual. Ensayo sobre las formaciones sociales del capitalismo periférico Fontanella. Barcelona.

Alfonso, A. Saintout, F. y otros (2007). 70 años de Periodismo y Comunicación en América Latina. La Plata. Ediciones de Periodismo y Comunicación, EPC.

Allegretti, S. y Vidarte Asorey, V. (2004) "La realidad mirada desde la ficción en la dictadura de Onganía". La Plata. Facultad de Periodismo y Comunicación Social, UNLP.

Argumedo, A. (2004) Los silencios y las voces en América Latina, Notas sobre el pensamiento 
nacional y popular: Ediciones del Pensamiento Nacional, Colihue.

ARI, "Informe sobre Hábitat": (www.legislatura.gov.ar/documentos). Consultado en enero de 2007.

Auyero, J.y Grimson, A. (1997) "Se dice de mí, notas sobre convivencia y confusiones entre etnógrafos y periodistas". Buenos Aires. Revista Apuntes de investigación N 1.

- (2001) La política de los pobres. Buenos Aires. Manantial.

- (2004) Clientelismo político. Las caras ocultas. Buenos Aires. Capital Intelectual.

_ y Swistun, D. (2008) Inflamable. Buenos Aires. Paidós.

Basualdo, Aspiazu y otros, (2002) El proceso de privatización en Argentina. La renegociación con las empresas privatizadas. Revisión contractual y supresión de privilegios y de rentas extraordinarias.Avellaneda. Editorial La Página S.A., Universidad Nacional de Quilmes. Baudrillard, J. y Morin, E. (2003) La violencia del mundo. Buenos Aires. Libros del Zorzal. Bauman, Z. (1999) Globalización, consecuencias humanas: Fondo de Cultura Económica. Buenos Aires.

- (1999) Modernidad líquida. Buenos Aires. Fondo de Cultura Económica.

(2006) Confianza y temor en la ciudad. Barcelona. Arcadia. 2006.

Beccaria, L. y M. González Rozada (2002). "La distribución del ingreso en Argentina, 1974 2000": Revista CEPAL N 78. CEPAL. Santiago de Chile.

Becker, H. (2009) Outsiders, hacia una sociología de la desviación. Buenos Aires. Siglo XXI 
Berger, P. y Luckman, T. (1968) La construcción Social de la realidad. Buenos Aires. Amorrortu.

_ (1997). Modernidad y Crisis de sentido: Paidós. Buenos Aires.

Blaustein, E. (2001) Prohibido vivir aquí. Una historia de los planes de erradicación de villas de la última dictadura. Buenos Aires. CMV, GCBA.

Bourgois, P. (2010) En busca de respeto. Buenos Aires, Siglo XXI.

Bourdieu, P. (1985) ¿Qué significa hablar? Economía de los intercambios lingüísticos. Madrid. Akal.

_ (1988). "Los usos del pueblo" en Cosas dichas. Barcelona. Gedisa.

- (1990) Sociología y cultura. México. Grijalbo/CONACULTA.

- (2001) El oficio de científico. Ciencia de la ciencia y reflexividad. Barcelona. Anagrama.

_ (1993) "Efectos de lugar" en La miseria del mundo. Buenos Aires. Fondo de Cultura Económica.

- (2003) El oficio del sociólogo. Barcelona. Anagrama.

Briceño Linares, Y. (2006) Del mestizaje a la hibridación: discursos hegemónicos sobre cultura en América Latina. Caracas. Centro de Estudios Latinoamericanos Rómulo Gallego.

BLUMER, (1969) Symbolic Interactionism. Perspective and Methode. Englewood Cliffs, N. J. Prentice Hall Inc. 
Casquete Badalho, J. (2003) "Norbert Elias: ensayo teórico acerca de las relaciones entre establecidos y forasteros", Revista de Investigaciones Sociológicas (REIS), Universidad del País Vasco.

Castells, M. (1971) Problemas de investigación en sociología urbana. Bilbao. Siglo XXI, _ (1974) La cuestión urbana. Méjico. Siglo XXI.

- (1986) La ciudad y las masas. Madrid, Alianza.

_ M., Borja, J. Benner, C. y Belil, M. (2007) La ciudad multicultural. Políticas para la interculturalidad. Barcelona. La Factoría, $\mathrm{N}^{\circ} 2$.

Chartier, R. (1994) Cultura Popular. Retorno a un concepto historiográfico. París, Manuscrits, $\mathrm{N}^{\circ} 12$, Gener.

Chávez, M. (2004) "Los espacios urbanos de jóvenes en la ciudad de La Plta". La Plata. Tesis doctoral, Universidad Nacional de La Plata.

Ciccolella, P. (1999). "Globalización y dualización en la Región Metropolitana de Buenos Aires. Grandes inversiones y reestructuración socioterritorial en los años noventa". Santiago de Chile. Revista EURE N 76.

Cieza, D. (2000) "De la cultura del trabajo al malestar del desempleo". La Plata. HCD, CREALC.

CLACSO(2009) Pobreza: Un glosario internacional. Buenos Aires: Consejo Latinoamericano de Ciencias Sociales.

Cravino, M. (1998). "Las organizaciones villeras en la Capital Federal entre 1989-1996. Entre 
la autonomía y el clientelismo": Buenos Aires.1 Congreso Virtual de Antropología y Arqueología.

_ M., Fournier, M., Neufeld, M. y Soldano, D. (2002). Cuestión social y política social en el Gran Buenos Aires. La Plata. Al margen.

_ (2008) Vivir en la Villa Relatos, trayectorias y estrategias habitacionales. Buenos Aires. UNGS .

- (2009) Los mil barrios (in)formales. Buenos Aires, Universidad Nacional de General Sarmiento.

Cuenya, Beatriz (1993): Programa de radicación e integración de villas y barrios carenciados de la Capital Federal. Buenos Aires. Municipalidad de la Ciudad de Buenos Aires.

De Certeau, M., Giard, L. y Mayol. P. (2006) La invención de lo Cotidiano. México. Instituto Tecnológico y de Estudios Superiores de Occidente.

de Sousa Santos, B. (2002) "Sin fronteras. En busca de la ciudad global". Porto Alegre. Foro Social Mundial (disponible en www.portoalegre2002.org).

Elías, N. y Scotson, L. (2000) Os establecidos e os outsiders. Río de Janeiro. Jorge Zahar Editor.

Fernándes, E. "Del código civil al Estatuto de la Ciudad: algunas notas sobre la trayectoria 
del Derecho Urbanístico en Brasil". Santiago de Chile. Revista Eure N 87. Ferrer, A. (1963) La economía argentina. Buenos Aires. FCE.

Forni, F. (2002) De la exclusión a la organización. Buenos Aires. Ciccus.

Freire, P. (1970) Pedagogía del oprimido. México. Siglo Veintiuno.

Fuchs y Vélez (2001). Argentina de rodillas. Terrorismo económico de Martínez de Oz a

Cavallo. Buenos Aires. Tribuna Latinoamericana.

Fuentes Navarro, R. (2002) agenda”. Bogotá. Diálogos de la ComunicaciónN64.

Fuenzalida Fernández, V. (2000) La televisión pública en América Latina. Buenos Aires. Fondo de Cultura Económica.

García Canclili, N. (1984) "Cultura y sociedad": una introducción", Cursos y Conferencias. Buenos Aires. Facultad de Filosofía y Letras, Universidad Nacional de Buenos Aires.

(1990) modernidad. México. Grijalbo.

(1997) Imaginarios Urbanos. Buenos Aires. Eudeba.

Gascón i Martin, F. (2001) "Complejidad y memoria de una asignatura pendiente". Lima. Revista Diálogos de la Comunicación $\mathrm{N}^{\circ} 63$.

Geertz, C. (1989) El Antropólogo como autor. Barcelona. Paidós.

Germani, G. (1973) El concepto de marginalidad. Nueva Visión. Buenos Aires.

Ginzburg, C. (2008) El queso y los gusanos. Barcelona. Península.

Goffman, E. (1979) Relaciones en Público. Microestudios del Orden Público. Madrid. Alianza 
Universidad.

_ (2009) La presentación de la persona en la vida cotidiana. Buenos Aires. Amorrutu.

- (2010) Estigma. La identidad deteriorada. Buenos Aires. Amorrortu.

Gonzáles S. J. (1981) "Sociología de las culturas subalternas". México. Cuadernos del TICoM, $\mathrm{N}^{\circ} 11$.

- (1994) Estudios sobre culturas contemporáneas: Universidad Colima. Colima.

Grimson, A. (2002) "Las sendas y las ciénagas de la cultura. Antropología y estudios de comunicación. La Plata. Revista Tram(p) as de la Comunicación y la Cultura N¹.

_ (2003). "La vida organizacional de las zonas populares de Buenos Aires", Informe final del proyecto "Urbanización latinoamericana a finales del siglo xx.". (http://www.prc.utexas.edu7urbancenter7Austin.htm ).

- (2004) Interculturalidad y comunicación. Bogotá, Norma.

_ y Semán, P. (2005) "Presentación: la cultura". Buenos Aires. Revista Etnografías contemporáneas $\mathrm{N}^{\circ} 1$.

Guber, R. (1991) El salvaje Metropolitano. Reconstrucción del conocimiento social en el trabajo de campo: Paidós. Buenos Aires, 2004..

Gutiérrez, J. (1999) La fuerza histórica de los villeros: Jorge Baudino Ediciones. Buenos Aires.

Hobsbawm, E. (1998) Historia del siglo XX. Buenos Aires. Crítica. 
Isla, A. Y Míguez, D. (2003) Heridas Urbanas. Violencia delictiva y transformaciones sociales en los noventa. Argentina, Editorial de las Ciencias.

Herzer, H. (2008) Con el corazón mirando al sur. Transformaciones en el sur de la ciudad de Buenos Aires. Espacio Editorial. Buenos Aires. 2008.

Kessler, G. y Gayol, S. (2002) Violencias, delitos y justicias. Buenos Aires, Manantial. - (2004) Sociología del delito amateur. Buenos Aires. Paidós.

Larrañaga, N. (1999) "El relato de vida". Tenerife. Revista Latina de Comunicación Social. Larraín (1986) Historia del Partido de Avellaneda. Reseña y análisis 1580 - 1980. Avellaneda. La Ciudad.

Lattes, A. E. y Lattes, Zulma R. de, (1992) "Auge y declinación de las migraciones en Buenos Aires". En Jorrat, J. y Sautu, R. Después de Germani. Exploraciones sobre estructura social de la Argentina. Buenos Aires. Paidós.

Laverdi, (1999) Na trilha das reivindicaçoes: movimientos populares de moradia em Sao Paulo e a luta pela Reforma Urbana na Constituinte. Maringá. Revista Diálogos Nº3.

Lomnitz, L. (1975). Cómo sobreviven los marginados. México. Siglo XXI.

López Accotto, A., Martinez, C., Grinberg, I. y Adaro, C. Nuevos Modelos de Gestión Local: La articulación de políticas públicas y el protagonismo ciudadano a través de la implementación del Presupuesto Participativo en Argentina. Revista Pueblos y Fronteras Digital [en linea]: 
[Fecha de consulta: 27 de mayo de 2014].

Martín Barbero, J. (1987) De los Medios a las Mediaciones. Méjico. G. Gili.

- (1988) Procesos de comunicación y matrices de cultura. Itinerario para salir de una razón dualista. México, Gustavo Gili.

_ (1989) "De los intermediadores a los mediadores". Bogotá. Conferencia presentada en el seminario Colcultura sobre Periodismo Cultural.

- (1991) "Dinámicas urbanas de la cultura". Medellín. Revista Gaceta de Colcultura N 12.

- (1998) "De las hegemonías a las apropiaciones. Formación del campo latinoamericano de estudios de comunicación". Bogotá, Asociación Boliviana de Investigadores de la Comunicación. - (2002) La globalización en clave Cultural: una mirada latinoamericana. Guadalajara. Departamento de Estudios Socioculturales, ITESO.

_ (2002). "Culturas populares" en Altamirano, C. Términos críticos de sociología de la cultu Buenos Aires. Paidós.

Mattelart, A. y Neveu (2004) Introducción a los Estudios Culturales. Buenos Aires. Paidós. Mela, A. "Ciudad, comunicación, formas de racionalidad". Bogotá. Revista Diálogos N²3. Merklen, D. (1997) "Organización comunitaria y práctica política". Buenos Aires. Revista Sociedad $\mathrm{N}^{\circ} 149$.

- (2001) Pobres ciudadanos. Las clases populares en la era democrática (1983-2003). Buenos Aires, Gorla. 
Míguez, D. (2004) Pibes Chorros. Estigma y Marginación. Buenos Aires. Capital Intelectual. - y Semán, P. (2006) Entre Santos y piquetes: Las culturas populares en la Argentina reciente. Buenos Aires. Biblos.

Minujin, A. 1997. En la rodada, de Cuesta abajo. Los nuevos pobres: efecto de la crisis en la sociedad Argentina. UNICEF/LOSADA, Buenos Aires.

Morin, E. (1996). Introducción al Pensamiento Complejo. Barcelona. Gedisa.

Mead, H. (1972) Espiritu, persona y sociedad. Paidós. Barcelona.

Nun, J. (1970) "Superpoblación relativa, ejército industrial de reserva y masa marginal" en Revista Latinoamericana de Ciencias Sociales. Vol. 4, N². Santiago de Chile.

Ortiz, R. (1985) Cultura brasileira e identidade nacional. San Pablo. Brasiliense.

- (1989)" Notas históricas sobre el concepto de cultura popular". San Pablo. Revista Diálogos de la comunicación $\mathrm{N}^{\circ} 23$.

- (2000) "América Latina. De la modernidad incompleta a la modernidad - mundo". Caracas. Nueva Sociedad $\mathrm{N}^{\circ} 166$.

- (2004) Taquigrafiando lo social. Méjico, Siglo XXI.

Park, R. (1999) La ciudad y otros ensayos de ecología urbana. Barcelona. El Serbal.

Pereira, G. (1995). "Comunicación, cultura y ciudad". Revista Signo y Pensamiento N 27. 
Portes, A., Roberts, B. y A. Grimson. (2005)Ciudades Latinoamericanas. Un análisis Comparativo del nuevo siglo: Prometeo. Buenos Aires.

Programa de Radicación de villas y barrios carenciados de la Capital Federal. Secretaría de Planeamiento urbano y Medioambiente. Municipalidad de la Ciudad de Buenos Aires. Creado en 1991.

Pasquali, A. (1979) Comprender la Comunicación. Caracas. Monte Avila Editores.

_ (1980) Comunicación y Cultura de Masas. Caracas. Monte Avila Editores.

Peirce, C, (1988) "La fijación de las creencias" en El Hombre, un signo. Barcelona. Crítica. Pereira, G. (1995). "Comunicación, cultura y ciudad". Bogotá. Revista Signo y Pensamiento Nº 27.

Portantiero, J. (1999) Los usos de Gramsci. Buenos Aires, Grijalbo.

Portes, A. Roberts, B. y Grimson, A. (2005) Ciudades Latinoamericanas. Un análisis Comparativo del nuevo siglo. Buenos Aires. Prometeo.

Quijano, A. (1971) "La formación de un universo marginal en las ciudades de América Latina" en Castells, M. Imperialismo y urbanización en América Latina. Gustavo Gilli. Barcelona.

Reguillo, R. (1997) "El oráculo en la ciudad: creencias, prácticas y geografías simbólicas. ¿Una agenda comunicativa?". Revista Diálogos de la Comunicación. N 49. 
(1997) "Ciudad y comunicación: densidades, ejes y niveles". Revista Diálogos de la Comunicación $\mathrm{N}^{\circ} 47$.

(2000) "Identidades culturales y espacio público. Un mapa de los silencios". Bogotá. Diálogos de la Comunicación $\mathrm{N}^{\circ}$ 59-60.

_ "Textos fronterizos. La crónica, una escritura a la intemperie", Diálogos de la Comunicación, $\mathrm{N}^{\circ} 58$.

(2008) "Sociabilidad, inseguridad y miedos. Una trilogía para pensar la ciudad contemporánea". México. Alteridades, $\mathrm{N}^{\circ} 39$.

Rodulfo, M. (2003) "La situación habitacional y las políticas públicas". Buenos Aires (disponible en www.urbanred.ungs.com.ar) .

Ribeiro, L. (2009) "La percepción de lo extraño. Contribuciones teóricas para la comprensión de los procesos de exclusión social: Simmel, Schütz, Elias y Bauman". Santiago de Chile. Revista Sociedad Hoy.

Rodríguez, M. Carla, Di Virgilio, M. Mercedes y otros, (2007) Políticas de hábitat, desigualdad y segregación espacial en el área metropolitana de Buenos Aires. Buenos Aires. Instituto de investigaciones del Instituto Gino Germani -Universidad Nacional de Buenos Aires.

Romero, J. L. (1965) Breve historia de la Argentina. Buenos Aires. Eudeba. 
Sachs, W. (1996), Diccionario del desarrollo. Una guía del conocimiento como poder. Lima. PRATEC .

Saintout, F. (2002) "Medios, identidades y políticas sociales". Buenos Aires. Revista Signo y Pensamiento $\mathrm{N}^{\circ} 41$.

_ (2006) El futuro llegó hace rato. La Plata. Ediciones de Periodismo y Comunicación Social, EPC.

Samaja, J. (1994) Epistemología y metodología: elementos para una teoría de la investigación científica. Buenos Aires. EUDEBA.

- (2006) Semiótica de la ciencia. Los métodos; las inferencias y los datos a la luz de la semiótica como lógica ampliada. Texto inédito.

Sánchez Ruiz, (2002) "La investigación latinoamericana de la comunicación y su entorno social". Revista Diálogos N 64 .

Sarlo, B. (1991) Instantáneas del fin de siglo. Medios, ciudad y costumbres en el fin de siglo. Buenos Aires, Ariel, 1991.

Sarlo, Beatriz (1991) Instantáneas del fin de siglo. Medios, ciudad y costumbres en el fin de siglo. Buenos Aires, Ariel.

Sassen, S. (1999) La ciudad global. Buenos Aires. Eudeba.

Sautu, R. (2004) El método biográfico. Buenos Aires. Lumiére.

Segura, (2006) "Segregación residencial, fronteras urbanas y movilidad territorial". Buenos Aires. Cuaderno IDES $\mathrm{N}^{\circ} 9$. 
Semán, P. (1993). "Pentecostales: un cristianismo inesperado". Buenos Aires. Revista Punto de Vista, $\mathrm{N}^{\circ} 45$.

_ (1997). "Religión y cultura popular en la ambigua modernidad latinoamericana". Caracas. Revista Nueva Sociedad, No.149.

- (2004). La Religiosidad Popular: creencias y vida cotidiana. Buenos Aires. Capital Intelectual.

Soldano, D. (2000) "Proximidades y distancias, el investigador en el borde peligroso de las cosas". Buenos Aires. Revista Apuntes de Investigación N 5.

_ y Fournier, M. (2001) "Los espacios en insularización en el conurbano bonaerense: una mirada al lugar de las manzaneras", Tercera Jornada Anual de Investigación de la Universidad Nacional de General Sarmiento, Los Polvorines.

_ (2006), Problemas de Política social en la Argentina

(2008) "Vivir en territorios desmembrados. Un estudio sobre la fragmentación socioespacial y las políticas sociales en el Área Metropolitana de Buenos Ares" en Ziccardi, A. (comp.) Procesos de urbanización de la pobreza y nuevas formas de exclusión social. Bogotá. Siglo del Hombre.

Solomianski, A. (2004) Identidades secretas. La negritud argentina, Buenos Aires. Beatriz Viterbo.

Spivack, G. (1985) "Can the Subaltern Speak?" en Nelson, C. y Grossberg, L. Marxism and the Interpretation of Culture. Illinois. Urbana. University of Illinois Press, 
Svampa, M. (2005) La sociedad excluyente, la Argentina bajo el signo del neoliberalismo. Buenos Aires. Taurus.

- (2008) Cambio de época, movimientos sociales y poder político. Buenos Aires. Siglo Veintiuno.

Taylor, S. y R. Bogdan (1998) Introducción a los métodos cualitativos de la investigación. Barcelona. Paidós.

Tonella, C. (2008) "Políticas urbanas y participación democrática en Brasil: El Consejo de las Ciudades". San Pablo. Revista Tempo da Ciência N 15.

Torrado, S. (1994) Estructura social de la Argentina (1945 - 1983). Buenos Aires. Ediciones de la Flor.

(2003). Historia de la familia en la Argentina moderna (1870-2000). Buenos Aires. Ediciones de la Flor.

- (2004) La herencia del ajuste. Buenos Aires, Capital Intelectual.

Torres, H. (1991) El mapa social de Buenos Aires (1940-1990), Buenos Aires. Dirección de Investigaciones. Secretaría de Investigación y Posgrado. Facultad de Arquitectura, Diseño y Urbanismo. Universidad nacional de Buenos Aires.

Trías, Vivian (2008) Simón Bolívar y el nacionalismo del Tercer Mundo. Caracas, El perro y la rana. 
Vasallo De Lópes, I. (1999) "La investigación de la comunicación: cuestiones epistemológicas teóricas y metodológicas". Lima. Diálogos de la Comunicación $N^{\circ} 56$.

Velho, G. (1979). Desvío e divergência. Uma crítica da patología social. Rio de Janeiro. Zahar.

Verzeilles, J. (1997) Historia Argentina. Etapas económicas y políticas (1950-1983): Biblos. Buenos Aires.

Vich, V. y Zavala, V. (2004) Oralidad y poder. Herramientas metodológicas. Buenos Aires. Norma.

Vidarte Asorey, V. (2005) "Navegar 30 años (Reseña crítica de 30AÑOS DESPUES, de Aníbal Ford)". Revista La Plata. Question $\mathrm{N}^{\circ} 6$.

_ (2007). "Exclusión y Políticas públicas en Buenos Aires." Mendoza. XI Jornadas Nacionales de Investigadores en Comunicación, Red de investigadores en comunicación.

(2008)"Epistemología, dialéctica y comunicación. La importancia de la reflexión epistemológica en los estudios de comunicación social". Valparaíso. Revista F@ro Nº 7, Universidad de Playa Ancha.

_ (2009) "Del conventillo al gueto". La Plata. Revista Question N²3.

_ (2009) "Territorio y exclusión social en Buenos Aires. Análisis desde la comunicación / cultura". Revista Cuaderno Urbano. Espacio, cultura y sociedad $N^{\circ} 8$. Resistencia Editorial de la Universidad Nacional del Nordeste. 
_ (2010) "Ni penas, ni olvido. Redes de relaciones organizacionales al sur de Buenos Aires". La Plata. Tesis de Maestría, Universisdad Nacional de La Plata.

Wacquant, L. (2000) Las cárceles de la miseria. Buenos Aires. Manantial.

(2001) Parias Urbanos. Marginalidad en la ciudad a comienzos del Milenio. Buenos Aires, Manantial.

- (2010) Las dos caras de un gueto. Ensayos sobre marginalización y penalización. Buenos Aires, Siglo XXI.

Wainerman, C. y Sautu, R. (1997). La trastienda de la investigación. Buenos Aires. Editorial Belgrano.

Williams, R. (1976) Las palabras clave, un vocabulario de la cultura y la sociedad. Buenos Aires. Nueva visión.

- (1982). El campo y la ciudad. Barcelona, Paidós.

- (2001) Cultura y Sociedad: Nueva Visión. Buenos Aires.

Zaffaroni, E. (2011) La palabra de los Muertos. Buenos Aires. EDIAR.

- (2011) La cuestión criminal. Buenos Aires. Planeta. 